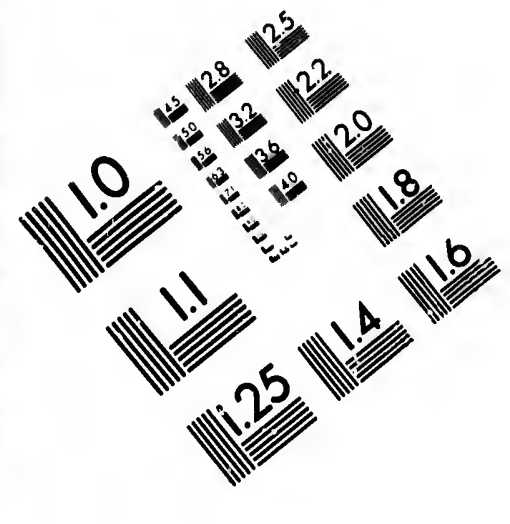

IMAGE EVALUATION

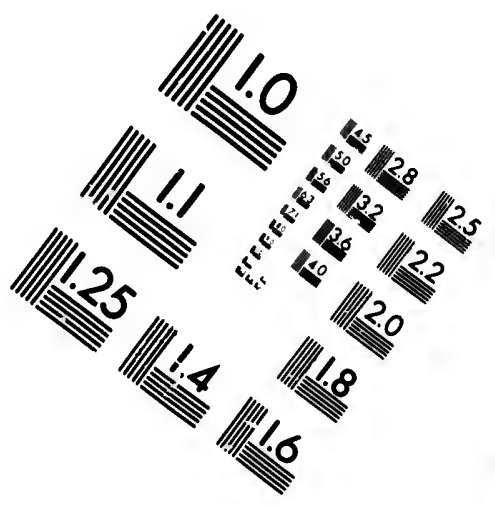

TEST TARGET (MT-3)
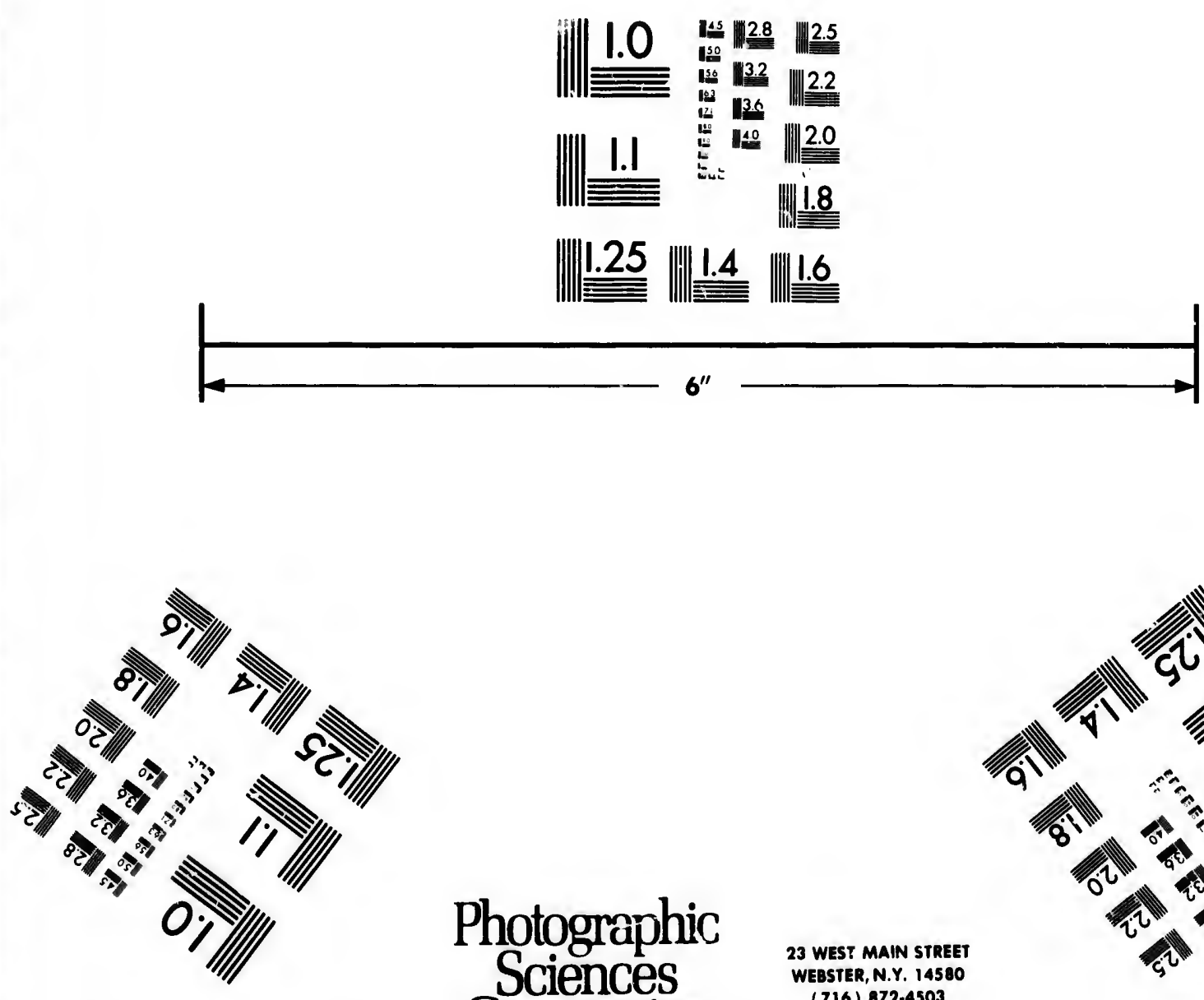

Photographic Sciences
Corporation

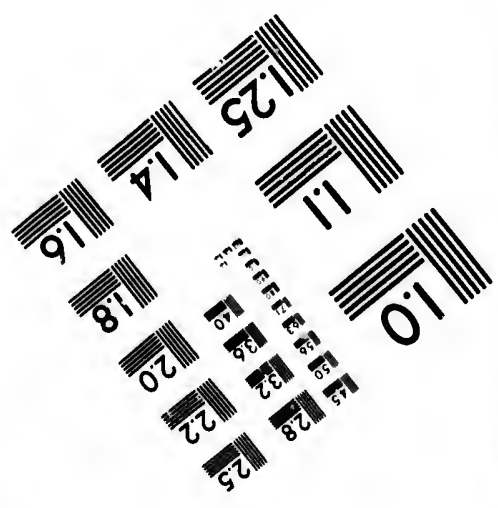




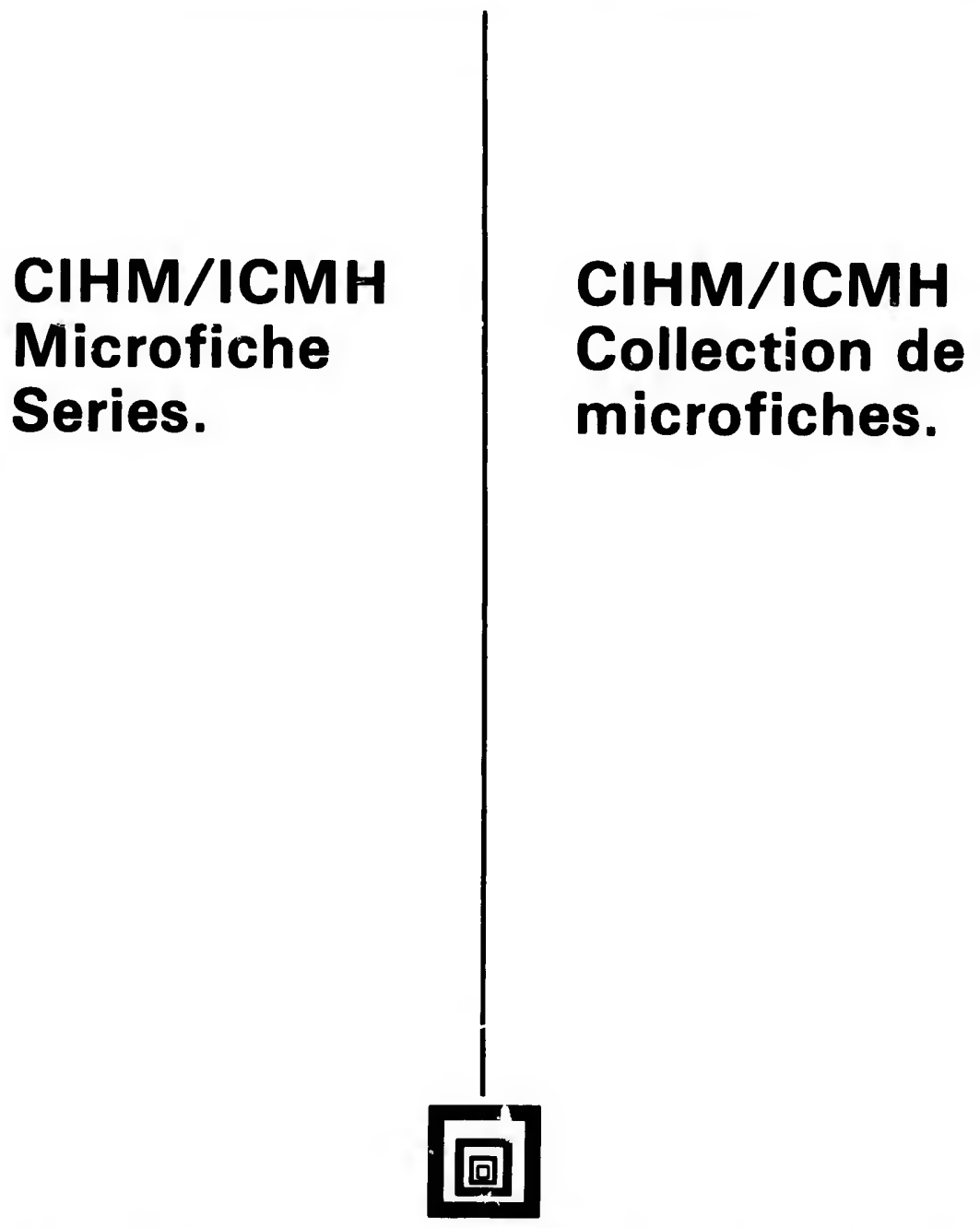

Canadian Institute for Historical Microreproductions / Institut canadien de microreproductions historiques
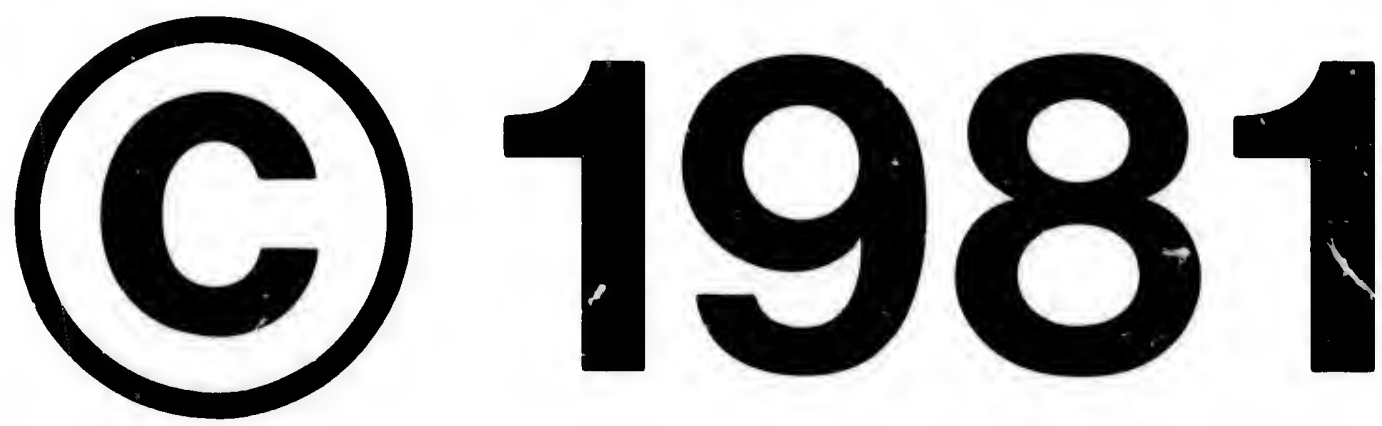
The Institute has attempted to obtain the best original copy available for filming. Features of this copy which may be bibliographically unique, which may alter any of the images in the reproduction, or which may significantly change the usual method of filming, are checked below.

Coloured covers/

Couvezture de couleur

Covers damaged/

Couverture endommagée

Covers restored and/or laminated/

Couverture restaurée et/ou pelliculée

Cover title missing/

Le titre de couverture manque

\section{Coloured maps/}

Cartes géographiques en couleur

Coloured ink (i.e. other than blue or black)/

Encre de couleur (i.e. autre que bleve ou noire)

Coloured plates and/or illustrations/

Planches et/ou illustrations en couleur

Bound with other material/

Relié avec d'autres documents

Tight binding may cause shadows or distortion along interior margin/

La reliure serrée peut causer de l'ombre ou de la distortion le lor. $\mathrm{J}$ de la marge intérieure

Blank leaves added during restoretion may appear within the text. Whenever possible, these have been omitted from filming/

II se peut que certaines pages blanches ajoutées lors d'une restauration apparaissent cians le texte. mais, lorsque cela ótait possible, ces pages n'ont pas été filmées.

Additional comments:/

Commentaires supplémentaires:
L'Institut a microfilmé le meilleur exemplaire qu'il lui a été possible de se procurer. Les détails de cet exemplaire qui sont peut-être uniques du point de vue bibliographique, qui peuvent modifier une image reproduite, ou qui peuvent exiger une modification dans la métlıode normale de filmage sont indiqués ci-dessous.

Coloured pages/

Pages de couleur

Pages damaged/

Pages endommagées

Pages restored and/or laminated/

Pages restaurées et/ou pelliculées

Pages discoloured, stained or foxed/

Pagas décolorées, tachetées ou piquées

Pages detached/

Pages détachées

\section{Showthrough/}

Transparence

Quality of print varies/

Quslité inégale de l'impression

Includes supplementary material/

Coinprend du matériel supplémentaire

Only edition available/

Seule édition disponible

Pages wholly or partially obscured by errata slips, tissues, etc., have been refilmed to ensure the best possible image/ Les pages totalement ou partiellement obscurcies par un feuillet d'errata, une pelure. etc., ont été filmées à nouveau de façon à obtenir la meilleure image possible.

This item is filmed at the reduction ratio checked below/ Ce document est filmé au taux de réduction indiqué ci-dessous.

$10 x$ $14 \times$ $18 x$ $22 x$ $26 x$ $30 x$

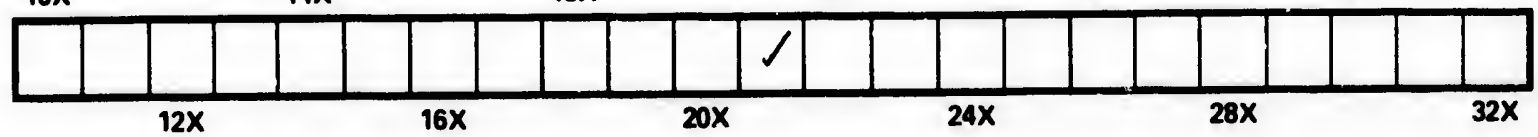


The copy filmed here has been reproduced thenks to the generosity of:

National Library of Canada

The images appearing here are the best quality possible considering the condition and legibility of the original copy and in keeping with the filming contract specifications.

Original copies in printed paper covers are filmed beginning with the front covir and ending on the last page with a pinted or illustrated impression, or the back cover when eppropriate. All other original copies are filmed beginning on the first page with a printed or illustrated impression, and ending on the last page with a printed or illustrated impression.

The last recorded frame on each microfiche shall contain the symbol $\rightarrow$ Imeaning "CON. TINUED"), or the symbui $\nabla$ (meaning "END"). whichever applies.

Maps, pletes, charts, etc.. may be filmed at different reduction ratios. Those too large to be entirely included in one exposure are filmed beginning in the upper left hand corner, left to right and top to bottom, as many frames as required. The following diagrams illustrete the method:
L'exemplaire filmé fut reproduit grâce à la générosité de:

Bibliotheque nationale du Canada

Les images suivantes ont été reproduites avec le plus grand soin, compte tenu de le condition et de la netteté de l'exemplaire filmé, et en conformité avec les conditions du contrat de filmage.

Las exemplaires originaux dont la couverture en papier est imprimée sont filmés en commençent par le premior plat et en terminant soit par la derniere page qui comporte une empreinte d'impression ou d'illustration, soit par le second plat, selon le cas. Tous les autres exemplaires originaux sont filmés en commençant par la première page qui comporte une empreinte d'impression ou d'illustration et en terminant par la dernière page qui comporte une telle empreinte.

Un des symboles suivants apparaîtra sur la dernière image de chaque microfiche, selon le cas: le symbole $\rightarrow$ signifie "A SUIVRE", le symbole $\nabla$ signifie "FIN".

Les cartes, planches, tebleaux, etc., peuvent être filmés à des taux de réduction différents. Lorsque le document est trop grend pour être reproduit en un seul cliché, il est filmé à pertir de l'angle supérieur gauche, de gauche à droite, et de haut en bas, en prenant le nombre d'imeges nécessaire. Les diagrammes suivants illustrent la méthode.

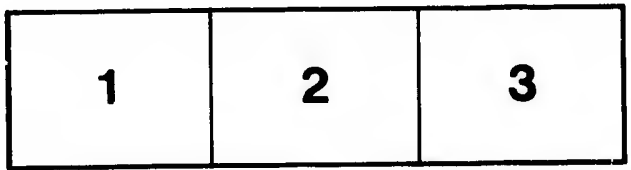

\begin{tabular}{|c|c|c|}
\hline 1 & 2 & 3 \\
\hline 4 & 5 & 6 \\
\hline
\end{tabular}

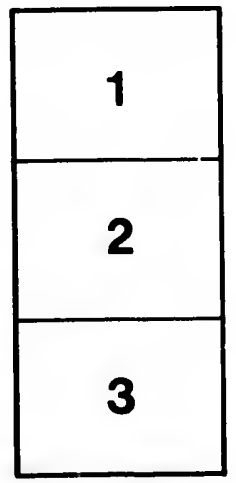




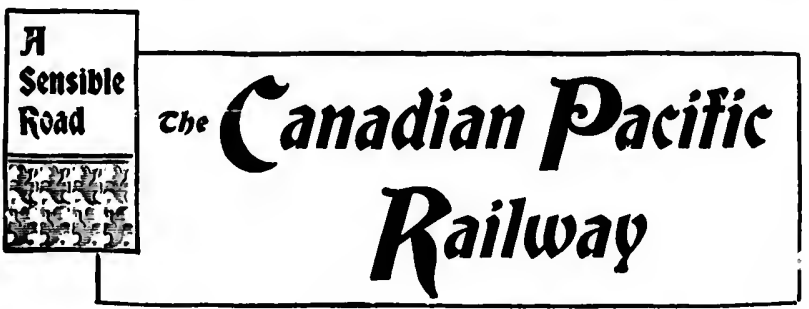

Is the most Substantiul and l'erfeotly l3uilt Rallway on the Continent of Americt, and superbly equiphed with the fluest rolling stock modern skill can produce. The Coarhes, bining und slepping Cars oxcel in stubllity and benuty of finish any other in thu world.

TOURISTS will find the Ronte lhrough Canada from the Atlantic to the Pacitic mapuroabled for matrnificence and varioty of scenery by nuy other lino of travel. The rugged wildness of the North Shore of hake superior, tle pieturesque Lake of the Woods gold region, the vast Prities of the Cunadiun North-West, the state!y grandeur of the laoekies, tho murvels of the Selkirks and Gold liunge, and the wondrons Beanty of the Pacife Const are truversed by this Ronte. Being entirely controlled and

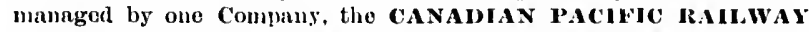
offers special advantiges to transeontinental travollers that camot be glven by any other line. It is the best the Safest and Fitstest Route from Oeen to Ocean. The Company has spared no expense in providing for the wants and comfort of its patruns, as its line of Ilining Cars and Monntuin Hotels will at all times testify, being supplied whth all that tho most fastidions cin desire. Through the Mountains Observation Cars ure run in the Tourist Seasou.

\section{THE ROYAL MAIL STEAMSHIPS}

\section{"EMPRESS OF INDIA" “EMPRESS OF JAPAN" "EMPRESS OF CHINA"}

Placed on the Paelfie by the Canadian Paeifle liailway ('ompung, bring that Womlerland, Japian, within the reach of all. Sixty days from New York will ulmit of ono month's holidity in Japan.

\section{THE CANADIAN-AUSTRALIAN LINE}

\section{R. M. SS. "MIOWERA" "WARRIMOO" and "AORANGI"}

Between Vineouver and Vietoria, B.C., and Sydney, Aust rulia, via Honolulu, Hawaiian Islinds, and I3risbane, Queensland, is the shortest and most attractive route to the Tropies ma Antipodes.

Through Tlckets from Halifax, St, John, N.B., Quebec, Montreal, Ottawa, Prescott, Brockville, Toronto, Hamliton, London, and all points in Canada; also from New York, Boston, and all points in the East, to Vancouver, Victorla, Skasway, and. other points in British Columbia and Alaska, and to Portland, Ore., Puget Sound Polnts, San Francisco, Japan, ChIna, Manlla, Corea, Straits Settlements, India, Hawallan Islands, Australla, New Zealand, and Around the World.

\section{INSIST ON GET'TING YOUR TICKETS VIA} THE CANADIAN PACIFIC RY. 


\title{
FISHING AND SHOOTING
}

\author{
NLONG THE LINES
}

WF 'TIE

\section{CANADIAN PACIFIC RAILIWAY}

\author{
IN TJE
}

Provinces of Ontario, Quebec, British Columbia, the Prairics and Mountains of Western Canada, the Maritime Provinces, the State of Maine and in Newfoundland

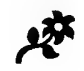

THIRTEENTII EIDTION

INSUEN BY THE

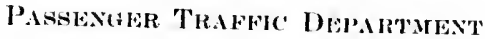

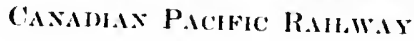




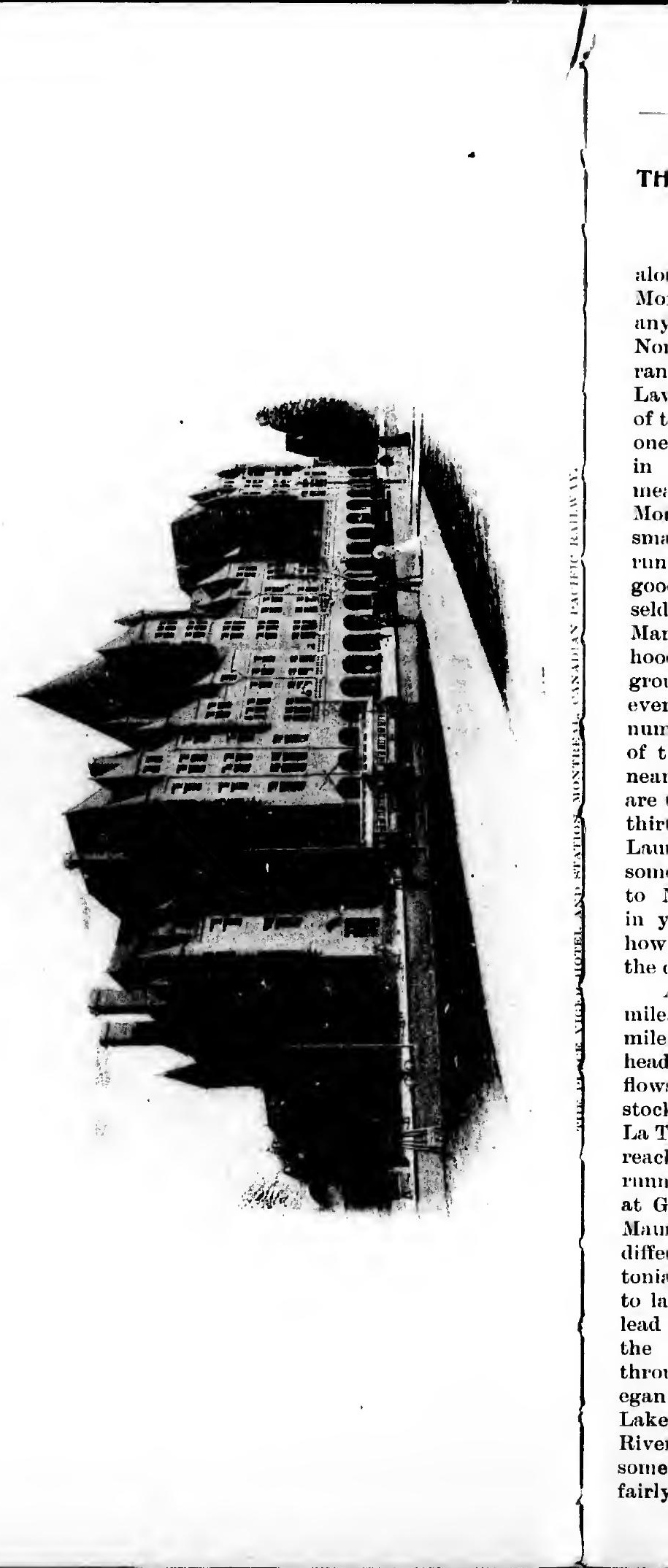




\section{THE NORTH SHORE OF THE ST. LAWRENCE EAST OF MONTREAL.}

'To try some of the small lakes and streams, so plentiful along the north shore of the St. Lawrence River between Montreal and (Nucbec, is a most satisfactory undertaking to anyone who is satisfied with killing fish of modernte weight. North of the river, some miles inland, the rugged Laurentian range of momntains p'uns parallel to the comrse of the St. Lawrence, and among them rise stream after strean, fetders of the multitudes of small lakes and the greater rivers, and in one and all trout are plentiful. This region is rough and wild in many places, ind to fish it properly not unfrequently menns "roughing it" to a certain extent. Anglers from Iontreal generally find good sport beyoud St. Jerome, in the sniall lakes and their feeders, these points being but a short run from Monteal. Half and three-cpuarter pound trout are good fish in these waters, and, while nuch larger ones are but seldom taken, there are plenty of the size mentioned. Si. Margaret and Ste. Agathe are stations in the sume neighborhood, but further distant from Montreal, in the centre of groups of lakes in which there is good fishing, the tront, however, being of moderate size ; St. Faustin is also the centre of numerous fishing. waters, and further north, at the terminus of the branch railway, is Labelle, 101 miles from Montreal, near which excellent sport may he obtained. Beyond Labelle are the Macaza and Nominingue districts, in the latter being thirty fishing lakes within a radius of four miles. In this Laurentian range are countless streams, lakes and lakelets, in some of which few lines have yet been cast, but their proximity to Montreal and easy accessibility are attracting anglers in yearly increasing numbers. For many years to come, however, they will rank amongst the best fishing waters of the continent.

Among the hills northward of St. Barthelemi, sixty-four miles east of Montreal and distant from that station fifteen miles, are waters that will be found well worth a trial. The headwaters and tributaries of the St. Iamrice River, which flows into the St. Lawrence at Three River's, are abundantly stocked with fair-sized fish. The St. Maurice is navigable to La Tuque, seventy-five miles north of Grandes Piles (which is reached by railway) and there is a regular line of steamboats rumning between these points. Good guides can be procured at Grandes Piles. It is possible to canoe by way of the St. Maurice Rivel and tributaries to Lake St. John by three different rontes; by Little Bostonias River, by Big Bostonias River and La Croche River, and thence from lake to lake. Fishing is good all the way across. Canoe rontes lead to the head waters of the Ottawa, the Gatineau and the Lievre. offering an indefinite number of waterways through a splendid game and fish region. The Shawenegan River, reached by stage from Lac a la Tortue (Turtle Lake) on the Grandes Piles Branch, reached from Three Rivers, usually furnishes heavy strings of trout as handsome and gamey as can be taken anywhere and big ones are fairly plentiful. The celebrated Mastigouche chain of lakes 
is reached by stige from St. Gabriel, the terminus of the Joliet brunch, and distunt from Montreal seventy-eight miles. Bryonil the Mistigonche are other lakes and waterways which afford splendiil sport for the rod und gun, and delightful outings in the cunoe.

The stution of Porturef, thirty miles from the city of Quebec, is a promising objective point. A drive from there abont 15 miles up she river will bring one to excellent fishing in the river above and below the falls.

There ure some good points for the angler nestr Quebec City, and he will find at the Chateau Frontenac, the palitial thre proof hotel on which $\$ 1,000,000$ has been expended, delight-

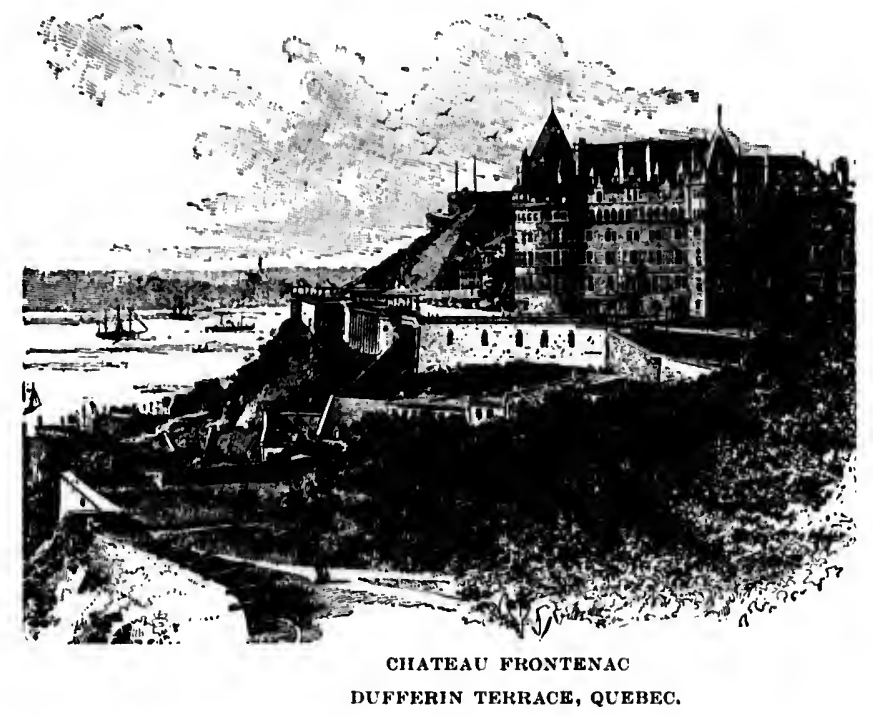

ful headquarte's from which to make excursions. The Chateau Frontenac, which ranks amongst the finest lotels of the continent and has recently been enlarged to meet the increased demands of travel, is picturesquely located on the celebrated Dufferin Terrace, and is the rendezvous of tourists and sportsmen from all parts of the globe.

Directly north of the city, 190 miles by the Quebec $\&$ Lake St. John Railway is Lake St. John, the home of the onananiche. Marvellous tales have been toll of this species, which is found in but few waters, and it is admitted that they are the gamest, strongest and hardest fighting fish that ever tested skill and tackle. It would be difficult to imagine a more attractive centre for the canoer ant the fishermen than this broad lake with its hunireds of miles of tribu. tary rivers extending far into a great unknown land. With skilled Indian guides the explorer can follow streams at will, penetrating the lonely haunts of big game in regions rarely visited by white men, travelling for days upon waters swarming with tront and finding sport unlimited. At Roberval, on Lake St. John, is a fine hotel, another at Grand Descharge, and steamers ply in the lake, from which the Saguenay flows

this

Line

ensy

point

ashol

territ

from

excee bilys, princi the $A$ streat the $\mathrm{lit}$ of the empti hotels there onribo Anna! up the and $l$, navige bogs a reacht taken. Aunar brookfine st

A

Mount State reach best $f$ grouse crossir Moose chain reache town o for spe enongh waters for an 
of the

iniles. erways lightful

city of m there ilshing

Quebec pulatial delight-

Chateau of the ncreased elebrated d sports.

c \& Lake he ollanspecies, admitted ting fish fienlt to he fisherof triburd. With s at will, is rarely s swarmerval, on escharge, hay flows to the St. Lawence. Lake Eilward, between Quelece and st. John, is anothej" axcellont flshing water at which there is also " good hotel.

Along the Lower St. Lawrence are many noted salmon fishing streams which 'an be renched by mail or stenurer.

\section{LAKE MEOANTIC AND MOOSEHEAD LAKE.}

It is not necessury to unclertuke a long jomrney to reach this attractive region. 'The Gundian Pacific Railway's "Short Line" from Montreal to the Muritime Provinees renders it ensy of access, and the traveller who makes Montreal his initinl point for this trip will find solid comfort ull the way, and only a short run by ruil hefore the Mecen of his pilgrimage is gained.

Laks Megantie is the largest body of water in the Canadian territory adjacent to Maine, being twelve miles in length by from one to four miles broad. Its shores are rugged and exceedingly pictmesque, and deeply indented with inlets and bays, the coast line measuring some forty odd miles. Its principal feeder's are the lower Spider and Arnold Rivers, nlso the Annance, Victoria and Sandy Rivers, and numerous lesser streaus, and its ontlet is the Chundiere River, which leaves the lake at the bay of the same name, within 100 yards or so of the Canadian Pacific Railway station at Megintic, and empties into the St. Lawrence near Quebec. There are severn! hotels in the village, and experienced guides can be secured there at modernte charges. The best localities for moose, earilon and deer are Annance Bog, near the wonth of the Annance River-which flows in at the head of the lake-and up the stream from its outlet for a conple of miles, the shores and log being furorite feeding grounds. The Annance is navigable by skiff or canoe as far as mentioned. Other good bogs and points for game will be known to the guides and raached under their directions.

Fishing in Megantic is variable, as is always the case on such large waters, but on a good day heavy strings will be taken. On Chandiere Bay, Moose Bay, the Victoria and Annance Rivers, and all the lesser streams and inlets, the brook-trout fishing is good, and there is no difficulty in taking fine strings of fish.

A short run by rail from Megantic over the Boundary Mountains, which divide the Province of Quebec from the State of Maine, enibles traveller's by the "Short Line" to reach one of Maine's most lovely sections, and also one of the best for sport-one of the most promising points for ruffed grouse and red deer being Lowelltown station. Shortly after crossing the international boundary the headwaters of the Moose River appear, the line following the stream and its chain of lakes elosely until the shore of Moosehead Lake is reached, and finally the Canadian Pacific Railway station and town of Grienville.

The headwater's and chain of lakes of the Moose River, in adclition to being gems of natural beanty, are first-rate for speckled trout, the fish running to good size, and plentiful enough to keep the rod busy. An exploration of this chain of waters would repay the labor, and furnish all the essentials for an enjoyable outing. Lakes and river extend for about 
twenty-flve miles before the current renches Moosehend Lake, the scenery being pretty and the greater portion of the wuter furnishing good llshing. The variely and quality of game to he found at the severnl pointribout these lakes and kindered waters, and others easlly jeached from Greenville station, mo nbeut the same as at Meguntic.

A glunce at a map will show why this part of Maine is such in noted gane and flsh countsy. Lakes aud ponds and smull strenms fairly net the whole region, offering fucilities for the trout flsher; and, as they threal the strongholds of moose, caribon, benr, and deer, the lover of the rifle cun rendily guess what opportunities are offered for the capture of one or all of the animuls mumed. In addition, (quite a number of duck and other game cun be fomm, and in such eover's as those shnggy woods ruffed grouse of cour'se abound.

Guides, necossuries for a eamping party, and information concerning the best points for sport, can he olituined at Greenville. Spencer, Indinu, Squnw. Wilson nud Roach ponds, Brassau Lake, and all the little streams that foed Moosehend, we noted for trout, and the guides can pilot you to many others. Those preferring to make their hendquarters ut Greenville will find accomodations in the hotels; plenty of bonts, and mmple menus of enjoyment; nul there are stemmers on the lake to take the visitor where ho wills.

Moosehead Lake is forty miles long hy from two to fifteen widi , with many islands, large mud small. The surromding hills: are lofty and covered with dense forests; and here and there a towering momtain rears high above the tungle of lofty woods, forming pictures of which the eye never wenries. Ginnclest of all is Monnt Kineo, at the base of which is the Kineo House, a commodious summer hotel with 250 rooms, and conducted in first-class style. Its appearance reminds one of the popular resorts of the sea-const, and it is the renulezvous for a small army of tomrists during the season. A large general store is elose at hand, where camp supplies, etc., muy be pureliased, and there are competent guides and good ennoes and skiff's availnble. An inviting trip) by (anoe can be made by leaving Moosehead Lake by the "north carry," portaging over to the West Braneh of the Penobscot River, and thence down stream, with good flshing, varied scenery (including Mount Katahdin, a huge muss of grunite), and a clash of adventure to lend an additionnl charn to the eruise. The East Branch of the Penobscot, the Allagash, St. John, and Aroostook are also reached by following the West Branch to Lake Chesumcook and thence north. The outlet of Moosehead Lake is distant from Greenville about twelve miles, and is the beginning of the Kennebec River. There is an hotel at Moosehead Station, and anglers can find aceommodation at the Carrys, at the head of the lake, the fishing, close at hand, being equal to many of the more remote localities. By going down stream in eanoes, Indian Pond and other trout pools are reached, and close to the river there will be found plenty of game.

Following the Canadian Pacific Railway's "Short Line" beyond Greenville, the route traverses for a considerable distance a similar country to that which has been referred to ; through favorite haunts of forest game, and passing many 
lakes, and erossing many trout streams, Lake Ouawn, or "Ship Pond," as it is also ealled, and Schoonlic Lake are mung these. By this line, which shortens the journey from Montreal to the Maritime Provinees ly nearly :310) miles, severul of the world-famous salmon rivers of Now Brunswick and Nova scotin are ensily renehed, and the advintuges it offers will be appreciated by all nportsmen.

\section{NEW BRUNSWICK}

Now Brunswick bas long had an unclablenged menutution us a lund for the hunter mul the flsheprum. One-third of the Province is good hunting ground. Its possibilities as a fleld for exploits with rod and rifle have not heon exaggernted by the unst anthusiastic writers, for merely the simple truth sufflees to do them justice. While the resources of the country in this respect are woll known, there is much to he songht ont in the little-explored forests and miely-fiecuentod lakes and strenms. Wach year adventurous sportsmon make discoveries of new worlels to conquer in their outing for the next season, and the man who visits the forests, lakes and streans of Now Brunswick once is therenfter to be cominted on as an anumul visitor. No part of America where game and tish are found is more ensily renched than New Brunswick is, and there are few trips where the expenditure can be kept within such rensonable bounds. With less than twenty-four hours of ensy ruilroul ride from Montrent or Boston, the truveller may alight in the centre of the hunting and fishing region, and in some instances lor may be so nea his eamp as to mike the rest of his way on foot, if he so desile. At all times dusing his stay he is within easy reach of the mails and telegraph lines, and so while apart from the busy world he may yet be in touch with it so far as occasion may retuile or his inclination prompt him.

Fron McAdam Junction, neir the Mane boundary, the whole Province lies open for a choice of routes to the stranger in search of sport. Should he desire an outing partly for the pleasures of a summer resort, free from the heat and the crowds of the fashionable resorts in the Unitel States, he may make his headquarter's at St. John, St. Andrews, St. Stephen, Fredericton, at all of which he will have plenty of society and enjoy all the comforts of life, with the lixuries as well if he is so inclinet. Yet from any of these points and from many smaller but comfortable resorts, he may rendily reach the hunting and fishing grourds. The enthusiastic sportsman, of conrse, will make the woods his home, but there are some who want a variety of recreation, and not wholly forest scenery.

St. Andrews has a high repute as a summer resort, with its hotel equal to that of any watering place on the coast, and its scenery which fears no rival among seaside resorts. There is fishing in both salt and fresh water. For the former, Passamaquoddy Bay and the Bay of Fundy give unlimited scope, while for tront, land-locked salmon and togue, are a number of lakes and streams at an easy driving distance. Among them are Chancook, Limeburner, Bartlett Stein's, Snowshoe, Welsh, Cram, Turner, McCullongh and 
Creasy Lakes, as well as the Digdeguash and other strenms. Once in St. Andrews, the visitor will find no lack of places in which to seek for and find fish. As to hunting, the woods in every direction abound with deer and a great variety of smaller game. The St. Croix at St. Stephen yieids the first salmon taken with the fiy in New Brunswick every year.

Between the boundary and St. John, along the line of railway, are a number of lakes and strenms of note, including Harrey, South Oromocto, Long and Victoria Lakes. These ard chiefly for trout, but if the visitor seeks salmon there is but the need of a iittle longer journey to rench the tributaries of the river st. John. There are, however, both trout and land-locked salmon in Skiff Lake, only three miles from Cunterloury station.

The Tobique is a stream of such great natural beauty that a mere sojourn nere in the summer would reward one. Its good looks are not the best part of it, however, for it is a great river for loth sahmon and tront. The main stren is more than sixty miles long to what are called the Forks, and these latter each have nearly as great a length. Both the main and the smuller streams afford gool fly fishing and the catches of trout by individual sportsmen have been the basis of many amazing lout strietly true big fish stories. The Tobique game country commences within twenty miles of the junction of the river with the St. John, and in all the regions through which the Tobique and its tributaries fiow are moose and caribou. 'The Tohicue is most conveniently reached from Perth Junction (opposite Andover, where guides can be secured) by the Tobique Valley buach of the C. P. Ry., which skirts the river up to Plaster Rock, where there is hotel accommodation and where conveyances can be hired to take sportsmen to the lakes further in the interior.

'To the south-west of this is the south-west branch of the Miramichi, reached from Bristol station by a drive of fifteen miles. There ure many points on this famons strenm for the axploits of the fisherman, and they can he easily learned by enquiry anywhere along the route. The Forks has a special reputation for salmon and tront. Of the branches, the best sulmon are in the Little Tobique and the finest trout in Camphell River. Tobique Lake is at the head of the Little Tobique, and has a fame for the sizo and abundance of the trout in its waters. From here, should one wish, a portage might be made to Nipisignit Lake, the headwaters of the stream of that name which enters into the Bay Chaleur. The Gulf shole of New Brunswick, with its streams, mu be reached by rail across the country from Fredericton.

Nenr Andover is a innch of the road running from Aroostook Junction into the State of Mnine by which the flshing and shooting of the famed country known as the Aroostook may be reached. There are n number of lakes and streams and all kinds of game in the woods.

At Gaand Falls, there is much to be seen in the natural wonders of the river and from there one may set out in whatever direction he pleases, with the assuri.nce of finding sport to rewnrd his trouble. Grand Fulls is a centre of oneration for anglers and sportsmen. Salmon and brook trout, wild 
reams.

ck of

huntand $a$ tephen aswick

of rail-

luding

These

here is

utaries

ut and

from

ty that

ie. Its

a great

$s$ more

d these

ain and

ches of

f many

e game

tion of

hrough

ose and

d from

can be

, which

is hotel

to take

of the t tifteen i for the ined by h special the hest trout in L Little e of the portis ge 5 of the ir. The may be 1y from hich the as the tkes and

nitural in whatng sport neration put, wild

geese, bluck duck, woodcoek and ruffed grouse are the game fishes and birds.

Edmundston is a place of considernble importance to the traveller, not only because it is the northern limit of his railway journey, but because it is in the heart of a district famed for its fishing. There are many waters from which to make a choice and all of them are good, for there is good fishing everywhere is the Upper St. John and all tributary and adjacent waters. From here, too, may be reached the headwaters of the Restigenche and of a number of streams that flow into the river St. Lawrence. In addition to trout, the large fish known as the touladi is abundant in this part of the country, as evidenced by the existence of Toledi Lake. A twenty-pound toledi is by no means a rarity and some are mueh larger. In the vicinity of Ednundston are such rivers as the Madawaska and Green River, and such lakes as the Temiscouta and Squatook. Twenty miles distant from Edmundston, and reached also from Curibou, is the Fish River, or Eagle Lakes, lying within the boundaries of Maine. Some eight lakes are connected with this river.

The country to the westward of Elmundston has not only deer and caribou, but moose. Splendid specimens of the latter, veritable monarchs of the forest, are seemed every season, and uncler the game laws of recent years there is likely to be moose hunting in many parts of the country where these animals resorted ycars ago. In fact, old guides and hunter's say moose are more abundant in some localities io-day than 25 years ago, and this is true of earibou in a greater degree, while red deer, once rather scarce, are yeurly becoming more obundant in various districts.

Taking St. John as a point of destination, the sportsman can not only have all his wants supplied in the way of ontfit, but he can learn from many trustworthy informants just where to make his choice of a river, lake or camping ground from which to secure the results songht in his individual case. The whole Province is before him, and there is a great variety of territory from which to choose. From this point, too, aceess to every part of the comtry is ensy, and, at the worst, whichever way he may go, the journey will be but a question of a few hours.

\section{NOVA SCOTIA AND NEWFOUNDLAND.}

Between Yarmonth and Sydney-the two extremities of Nova Seotia-there are spots which offer great attractions to the keen sportsman, either with the hook and line or with the gun. At the Tusket Lakes, near Yarmontl, in the country round Digby and at different points in the Annapolis and Cornwallis Valleys as weii as around the famed Bras d'Or Iakes and tributa"' waters in Cupe Breton and along all the south shore of the Province the opportumities for sport are excellent, the favorite haunts, as a rule, not being difficult of access. In some localities moose and other large game are found. The fishing and shooting regions of the western part of Nova Scotia are renched from St. John, N.B., by the fast steamer Prince Rupert, which makes daily trips, during the summer season, between that city and Dighy, there connectirg 
with the Dominion Atlantic trains for Yarmonth to the sonth, and Halifax to the east. From Halifax, there is regular communication by the Intercolonial Railway system with Cape Breton. This line also muns from St. John to Halifax, via Moncton and Amberst, connection being made at Truro for Sydney, North Sydney and other Cape Breton points.

By the inauguration of a new ronte during the summer of 1898 between North Sydney and Port aux Basque, the Island of Newfoundland was brought within easy distance of the mainland; and the grave objection of some to an ocean voyage practically avoided. The water trip occupies only six hours, and is made in the steamer Bruce. From Port aux Basque the centre of the Island is traversed, to the capital, St. John's, through the most favored fishing and shooting regions, which are thus made easily accessible.

Few countries present to the lovers of sport the attractions that Newfoundland possesses. Vast deer parks there are in the interior. The countless lakes and ponds abound with trout of the finest description, and are the feedingplaces of the wild goose, duck, and other iresh-water fowl. Finer salmon streams can scarcely be found.

Herds of caribou traverse the island in periodical migrations from south to north and furnish the highest prizes for the sportsman. September and Octolser are the months for stalking, and the assistance of guides is requisite. For the more adventurous, there are the black bear and the wolf in the interior; and the beaver and otter are found around the lonely lakes and lakelets. Hares are in abundance, and the willow grouse or ptarmigan, the rock ptarmigan, the curlew, the plover, the snipe, are found in the proper season all over the Island, on the great " barrens " or in the marshy grounds, and around the shores and islands are innumerable sea pigeons and guillemots, or " murrs" or "turrs" as they are called in the vernacular.

The climate in summer, tempered by the balmy sea breezes, is bracing and health-giving.

\section{SHARBOT LAKE.}

This lake is situated directly on the line of the Canadian Pacific Railway, being about 166 miles distant from Montreal, easily reached from Ottawa, and 169 miles from Toronto.

The attractions are the same as usually characterize Canadian lakes-forested shores, beautiful rocky islands, large and sinall, and clear cold water stocked with good fish.

The list of fishes that may be taken there are black and. rock bass, salmon trout, pike, and a few lunge, though the latter are seldonı killed.

There is hotel accom:nodation and boats to be had. This lake is a noted resort for duck in the fall. Many handsome bags have been made there.

\section{THE RIDEAU LAKES.}

A few miles north of the River St. Lawrence, in Ontario, and easily reached from Kingston, Brockville, and Smith's Falls, are the winsome Rideau Lakes, large, island-dotted bodies of crystal water. By the construction of the Rideau 
o the egular with alifax, Truro ts.

immer ie, the nce of ocean nly six rt aux apital, ooting

attrac- there abound eedingfowl.

nigraizes for ths for For the wolf in ind the and the curlew, all over counds, pigeons alled in

jeezes,

unadian ontreal, oronto. e Cana'ge and ck and. gh the

This adsome

intario, Smith's -dotted Rideau

Camal, a watery high way connecting the capital city of Ottawa and the historic city of Kingston was opened - a distance of 125 miles. When the canal was constructed the course of the Ride $u$ River was naturally followed, and the stream utilized as far as possible; and when the seveinl locks were completed, and the wateis restrained from flowing through their natural outlet, great tracts of low-lying woodland and marshy spots were deeply flooded, forming what are now known as the "Drowned Lands." The Rideau was always a fine bass water, and under the altered conditions it not only held its own, but so rapidly improved that it is now one of the best black-bass fishing water's in America. As the years passed and the flooded country ran wild, the entire aspect changed : broad marshes were formed, overgrown with wild rice and rushes, attracting thousands of duck and other water fowl. There is nothing, except an oecasional lock, to suggest to the voyager that he is upon anything but a great natural water highway, a broad stream widening every now and again into lakes of greater or less extent, with long stretches of rushes and beds of rice, weeds and lily-pads, such as are loved by duck and fish. Besides myriarls of bass, there are land-locked salmon. Tront and pickerel are also plentiful, and in the fall there is capital duck shooting.

On Iong Island will be found the Angler's Club House, a good hotel containing about forty roons, which is open to members of the elnb, which owns the island and hotel, also to their friends who have letters of introduction.

A canoe eruise of the lakes will be found thoroughly enjoyable. While making this trip by canoe you will pass many camps upon the shores, and meet many holiday-makers who are, like yourself finding healthy recreation in tracing out this pleasant route. By far the greater portion of the way is exceedingly pretty. A camp can be pitehed, almost inywhere; should you desire to stretch your legs a bit, you can land where you will. For those who prefer to spend their holiday anong pretty surroundings, and at the same time remain within reach of civilization, the Rideau offers many inducements. The route is easily reached and easily traversed, and there is no hardship conneeted with it. The entire trip is inexpensive, and has been male in a week, but that of comrse neessitated hard work at the paddles. A couple of weeks-or a month or longer-conld be pleasantly and profitaloly spent here. Should Kingston be selected as the starting point, tourists from east or west are best conveyed thither by the fine steaners that ply upon the St. Lawrence and Lake Ontario; for that trip by water is considered one of the most attractive available. If Ottawa or Sunith's Falls be chosen, either is reached from east or west direct by the Canadian Pacific Ry. Steamers run regularly between Ottawa and Kingston.

\section{THE RIVER TRENT AND ADJACENT WATERS ; AND PETERBORO.}

'This is one of the best available regions for the touristsportsuren and anglers, especially for those who make Toronto their starting point. Leaving Toronto by the Canadian Pacific Ry., Havelock station is reached within four hours, or 
in other words, you can leave Toronto in the morning and be busy with the black bass and lunge early in the afternoon, a feature that should bear due weight with those who have only a few days at their disposal. Havelock, distant 100 miles from Toronto, is the best point to select as headquirters, if a trial of the Trent is deeided upon ; and the angler or sportsman can take a trip, satisfied that, unless he is one of those unfortunate beings who scem specially selected as the victim of hard luck, he will be riehly rewarded for his trouble. Close to Havelock station there is $m$ hotel where visitors can make themselves at home, and pick up valuable pointers as to the best method for circumventing the lunge and bass that claim the Trent as their lome. Trent Bridge is only three miles from the hotel, and you cun secure conveyances at the latter place and be driven over, and are then on the spot. Boats and guides can be secured at the bridge at clieap rates, and to many the most enjoyable methor is to go into eamp) at one or other of the desirable sites along the stream. 'Those who do not faney spending a holiday under canvas can find aeconmodation close at hand. From almost the eommencement until the end of the open season the lunge and black bass fishing is Al, except on an odd day now and again, such as will be experienced upon any water. Above the brilge, towards the town of Hastings, trolling for lunge will give satisfaetory results, for the "fresh water shirks" are mumerous, and bite freely at either spoon or live minnow or chmb, and the catch will he varied with heary black bass. The righthand ehannel at the island, going down strean, and below the island for some miles to the govermment boon, are famous reaches for bass and linge. Lunge sealing all the way from five to tiventy or thirty pounds, have been taken, the smaller fish being plentiful. If yon want to have genuine fun with a big fellow, just troll for lunge at this point, using a stout rod and suitable tackle, and for a surety you will have a tussle now and then that will quieken your eirculation vastly, or you are no true lover of the gentle pastime. Fine strings of bass ean also be taken by still fishing all along the river, between Trent Bridge and Healy Falls and Rapids, a distance of about seven miles. 'The stream varies in width from 100 yads to a charter of a mile, and here and there expands into broad bays ; and at many points there are rocky shoals and gravel beds, where, as the bass fisher will guess, many fine fish are sure to be.

But the spot of spots for small-mouthed blick bass is below the falls. The stream plunges down fully forty feet over a rocky ledge some 100 yards wide, and among the deep pools below is where the bass are found in all their glory.

Abont a mile and in half below Healy Falls the Tient runs into Crow Bay, a noted spot for both lunge and bass, and one that is almost certain to well reward a trial.

Another excellent point on the Trent is Campbellford, twelve miles from Havelock station. $U_{p}$ and down stream from Campbellford a rod can be kept busy all clay and the fly fishing is good. If a letter is sent notifying the proprietor of Blute's Hotel, Campbellford, a conveyance will be sent to meet you at Havelock, and no further trouble need be taken, for all information as to fishing localities will be afforded.

Any one going to Havelock might as well write in advunee to insure boats and conveynnce, in order that no time may be 
lost in getting to work. By following this cou'se a goodly string should be taken ere night falls on the first day's onting.

One of the brightest towns of the more important centres of Canada is Peterboro, which nay be considered the birthplace of the modern eanoe. It is a convenient point from which to reach some fine lakes, including Stoney Lake, one of Canada's charning summer resorts where good bass and lunge fishing ean be had. Rice Lake, distant twelve miles, is reached by steamer daily, and is an admirable point for camping. There is hotel aecommodation at Jubilee Point and Idlewild. Chemong Lake is seven miles distant by rail, and Katachawanucka, nine miles. Live minnow bait will prove deadly with lunge and bass; the fishing is generally excellent, and a couple of weeks may be pleasantly spent with rod and canoe, at trifling expense. Fairly good duck and grouse shooting can be had, but deer must be sought at more distant point 3 .

North-east of Havelock is a fine sporting country, both for trout, deer and grouse. It has been very little worked. A sportsman call go to Rathbun, or Baneroft by rail, at both of which places there ire country hotels, and thence drive out into the country he intends to work.

\section{THE CHAIN OF LAKES NORTH OF THE TRENT.}

Ranging northward of Havelock is a region of forest, lake and stream, which combines picturesque scenery with good territory for fish and game. A far-reaching ehain of beantiful lakes extends through the wild country, all linked together by small streams navigable by canoes, excepting in a few cases, where portages have to be made. This ehain of lakes offers great inducements to canoeing and camping parties, and one can go with canoe and camera and find countless combinations of scenery too numerous for mention; or, if rod and gum are also taken, plenty of oceupation will be found for all.

The principal waters of the ehain are Round Lake, Belmont, Deer, Oak, Blue, Twin, Sandy, Jack, Cushamogabog, Tonomong, White, Gull, and Eagle Lake. On the north side of Round Lake North River runs in. This stream is navigable either by canoe or rowboat up to the "narrows," and here, after a portage of fifty yards, you can continue bearing northward into Bass Bay, and the fishing in these waters is good all the summer months. There are many eharming places along its banks on which to camp, and the distance to the nearest settlers is not sufficient to be a hardship.

Going by road from the North Bridge, the distance to the next waters of importance is abont ten miles. Oak Lake is a very pretty sheet of water, having numerous islands in it, and the bass fishing ean generally be relied on any time after the season opens. There are skiffs on this lake, and they can be rented at it reasonable cost, though we would advise anybody to make a sure thing of it ly taking along their own eanoe or bont. The portage from Oak to Cushamogabog Lake is about a quarter of a mile. and easily made. The latter lake is one of the most attractive in the whole worth country ; its surface is dotted with islands and its waters teem with bass.

Those who have used both minnow, frog and worm bait in these waters, found them all excellent. Bass a'e a 
notiony fish, and while some days they wouldn't look at a big fat, juicy dew wor'm, unother day they would seem to prefer. them to any other bait. Live minnows, however, are the most killing bait, as a genernl rule, and the re can be obtained in reasonable quantities at the lake. If you want a most enjoyable outing, on one of the most pieturesque lakes in Ontario, you cannot do better than decide on a week or two at Cushamogabog. The scenery is charming, the water very cold, even in August, the fish of a superb quality and firm as a rock. Take along your boat and camp outfit, then you can move around to suit yourself and change localities as often as the spirit moves you. Close by are numerous other lakes, all of them easily reached by driving over a very tair road. They are Blue Lake, Twin Lakes, Gull Lake, Eagle Lake, Tonomong, Sandy Lake, and other's still further north, but the group already mentioned are sufficiently numerous to furnish all the sport required by those who desire a pleasant outing, and with whom the time at their disposal is an important consideration.

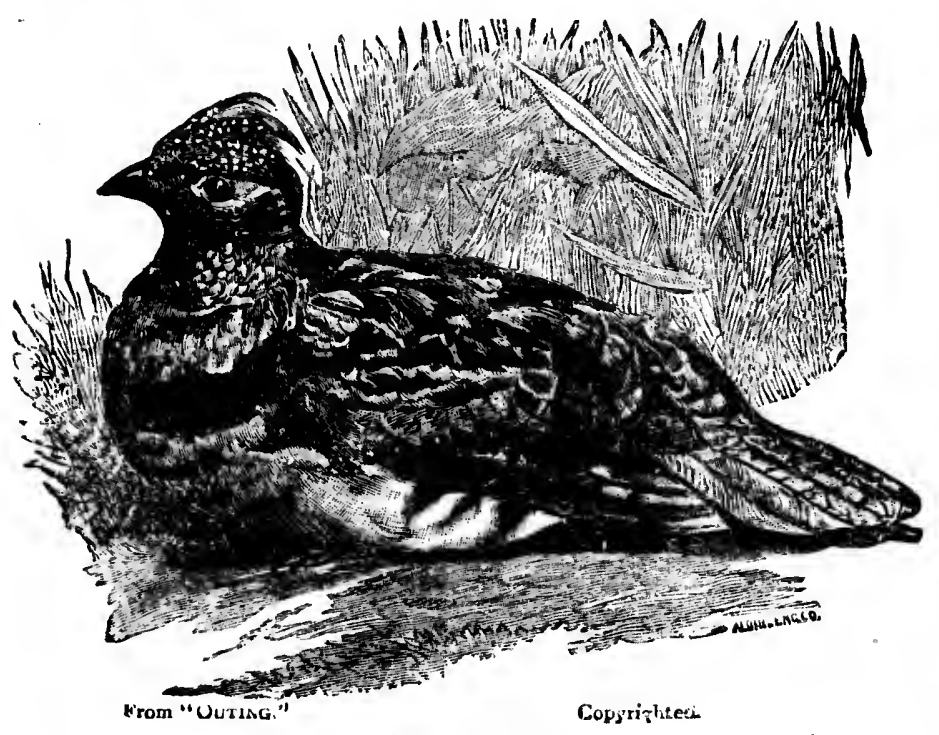

RUFFED GROUSE.

There is deer and partridge shooting through this whole section of country, and it is possible to obtain comfortable accommodation with some settler in many of the best shooting sections. The country is rocky and by no means easy to walk, but the sportsman who is prepared to take it as it comes, and can shoot reasonably straight when he sees game,

- will have no difficulty in killing all the deer the law allows him, and the bright, clear northern atmosphere will give him a mighty appetite.

Belmont Lake, a few miles east of Round Lake, is best reached from Havelock station, a three and a half mile drive, and rigs can be got at Havelock to take sportsmen to this place. There is a large boarding-house on the shores of Belmont 


\section{THE COVERS AND WATERS OF WESTERN} ONTARIO.

The Canadian Pneifle Ruilway between London, Ont., and the Detroit River, traverses well-known shooting yrounds. Here und there, in the sixty or more miles of country between London and Chatham, wild turkey are yet to be found. But the gane to be depended upon comprises quail, grouse,

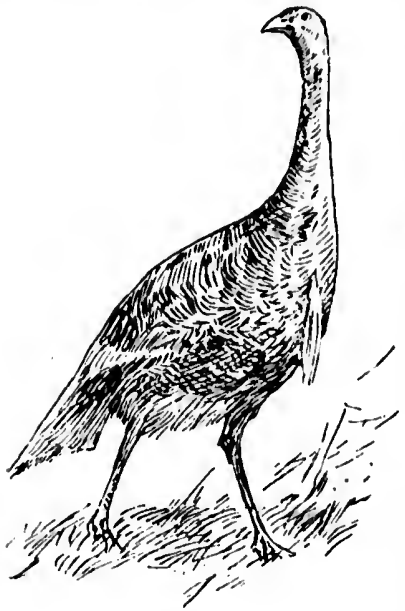
woodcock, rabbits, and a great variety of waterfowl, abounding in the western marshes. The clearing of farms and eultivation of vast tracts of eoumtry, in no wise affected the quail and rabbits, and the gronse but little.

Quail abound in all the western counties, but only in the western portion of Ontario are they fomnd in Canadian territory in sufficient numbers to afford sport.

They are wonderfully prolific, and fine sport can be had with them over good logs, and excellent bags nade. Very fair sport can be had at almost any point more than thirty miles west of London, the sportsmen also finding a few ruffed gronse, woodcock, and a number of rabbits while penetrating the covers in pursuit of a hevy of quail he has flushed. Plenty of birds can be found within comfortable driving distance of Chatham, say eight or ten miles; and one can put up at a country hotel along the main roads, or find quarters at a farm house. During past seasons important "Field Trials" have been held near Chatham, and birds were so plentiful that the trials were decided without much trouble, and there is every likelihood of the same grounds being used for years to come. At present the law forbids the sale of quail killed in Ontario; and this measure will insure a rapid increase in their numbers. From Chatham the Erie \& Huron Railway offers facilities for reaching the town of Blenheim, elose to Rondeau Harbor and Lake Erie, or in the other direction, the towns of Dresden and Wallaceburg, on the line, and hoth well-knowr resorts for sportsmen. Rondeau Harbor was formerly one of the best points for duck in the country, yet on a good day fair bags can be mide; the fowl are wild, and though thousands may be seen, but few are kiiled. There are, however, plenty of quail in the neighborhood; here and there ruffed grouse, and in the wet woodlands of the north shore a few woodcock early in the season. Dresden or Wallaceburg are better points for all round shooting. The fishing in the Ean, from its size, is variable. There is excellent plover and curlew shooting on the bars and beaches of the Lake Erie side, and, taken altogether, the Eau is a fairly good point for holiday with a rod and gun. 
Below Chatham wre the Lake st. Clair marshes, so frequently referred to by "Frank Forrester" in his works on shooting. In the spring wild geese flock to them en of yole; and those who like to air the breechloarler at this senson can have very good sport with the shy "honkers." The geese make their headquarters for a time in the

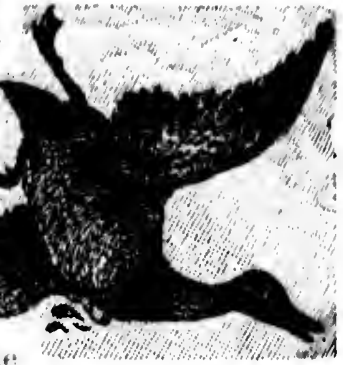
bays and ponds adjacent to Lake St. ('air.

These milrshes and unddy plains are fiunous snipe grounds, and the shooting is still good enough to be well worth a trial. Woodcock ar: also frequently found in the wet corn-fields early in the fall, and later in the dry thickets of the uplands where the quail hunt, aud rabbits are plentiful everywhere. Ru.:erl grouse may be found in the heary woods bordering the plains at several points, and not infrequently a fine mixed bag of grouse, cock, snipe, qunil, rabhit and duck is made by one gun in a couple of datys. Plover are numerous in the autumn. About the mouth of the Thames ind adjacent creeks and marshes, ant upon Lake St. Clair, are any numberof duck, though the good points for shooting them are comparatively few. The finest portions of these western mirshes are strictly preserved. Several very fine club houses have been erected on the preserves, incl those who desire can very often buy shares, and thus get grand shooting and everycomfort therein. Still, an ontsider can generally find a bit of sport worth going after at the points named; and, if he has good dogs and varies the programme by attending to the duck at early molning, and the quail later in the day, he should have a good time, and bag his share of what is going.

Fishing, both trolling and whipping with minnow or artificial bait, in and abont Baptiste and Jeanette's Creeks (both near the mouth of the Thames) and in and about the mouth of that stream, is generally good, the catch including black, rock and speckled biss, pike, pickerel anul perch. The mouth of the 'Ihaunes is reached from Chatham by steamer' plying to Detroit, for a mere trifle for transportation, and you can camp upon the beach where the Thames joins Lake St. Clair, or find accommodation for a small party at the lighthouse.

At Mitchell's Bay, on Lake St. Clair, reached either from Wallaceburg or by driving from Chathain, are hotels, and, as a general thing, duck shooting and black bass fishing.

The Credit Forks Trout Preserve, situate abont forty-five miles northwest of Toronto, is reached by the Canadian Pacific Railway, by taking train to Forks of Credit station and then driving about two miles. The fish which abound in these waters are of three varieties, viz.:-the ordinary native speckled trout, the California rainbow or mountain trout, and the German brown or Van Buren trout. Ample accommodation for sportsmen may be had on reasonable terms during the open season. Fishing is let out by paying so much per pound for what is eaught. Further information may be had by writing to proprietor above preserves, Credit Forks, Ont. 


\section{THE MISSISSIPPI RIVER AND LAKEJ.}

Carleton Junction, on the line of the Canalian Pacifle Railway, 146 miles from Montreal,23 miles fro:n Otta wa, and 225) miles from Toronto, is the station for these writers. $\Lambda$ t the juncthon are a couple of hotels, and a five minutes' walk will take you to the town of Carleton Place. Men and boats can be securef at the usunl 1ates. The Mississippi River runs through the town, and it is in pluces a rapid stream, fonming and boiling over rocky ledges and big boulders, with many deep, quiet pools and eddies, in the shadows of which lurk black and roek bass. The rlver is easily flshed and heavy black fellows can be taken from it, and rock bass unlimited; but a better point is the fir'st enlargement of the winding river known us Mississippi Lake. This lake is three miles from Carleton Plnce, and atfords good sport, large black bass being readily hooked. Fair-sized pike are plentiful, lunge are scaree, but rock bass may be taken by the dozen nlmost anywhere. In the fast eurrent of the river, spoons, artificial minnows, etc., are good, but the most deadly bait is either minnow or crayflsh. A couple of miles nhove Mississippi Lake is another and smaller lake, which is, perhaps, the best of the waters. On either of them trolling with an ordinary spoon, or still-flshing with worms, will answer admirably. Particular's about the most promising reaches can be obtatiued at Carleton Place, and at Park Lake, three miles from Carleton Place, where there is a sumner resort hotel.

Some exceedingly good catches are on record for these waters, and in the fall there is now and again some fairly good shooting-duck, snipe and woodeock-but hurdly sufficient to merit special attention, though as a fishing resort it is well worth a visit.

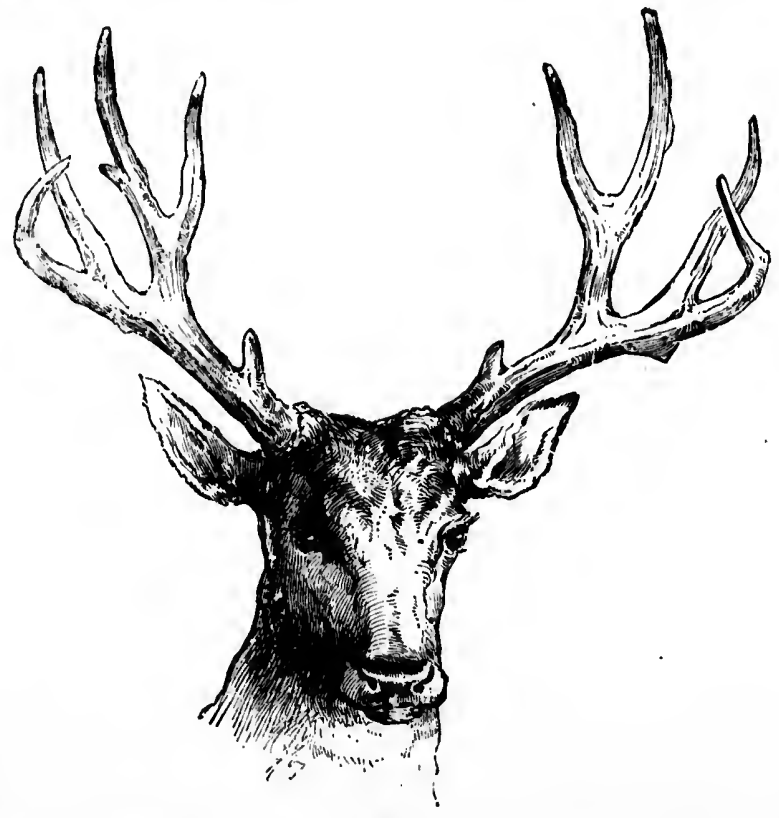


Pacifle and 2:5; 10 junceke you secured hrough ng and many h lin'k heavy mited; g river from k bass ige are it anytifieial either issippi s, the ith in unswer eaches three resort

these fairly sufflort it is

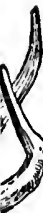

\section{THE OTTAWA RIVER AND ITS TRIBUTARIES.}

The transcontinentul liue of the Canadian Pacifle Rnilwny, in its course from (arleton, Junction to Winnipeg, triverses for the greater part of the way a region of country that for sporting purposes can luarlly be excelled by anything outside of the maguiflcent game resorts and trout water's of the Rocky Mountains and the wonderful prairies of the Cunadian Northwest. 'Those, of comrse, tre not npproached by any territory on the Amerienn continent ; but the sportsunal who lus not time to devote to the transcontinentul tour ('un find all the sport he wants, and willly beautiful scenery, second only to the momtnins, and never jouruey a yord beyond Nepigon River. And if that wonderful strenm is too fur away for the time at command, ous need not go beyond the Ottawa River and its tributaries to give rod and rifle full play, Sport such as no man should complain of tan be enjoyed at will : trout of good size can be taken in numbers; and in these lonely forests are moose, emilon, deer, bear, grouse, and other

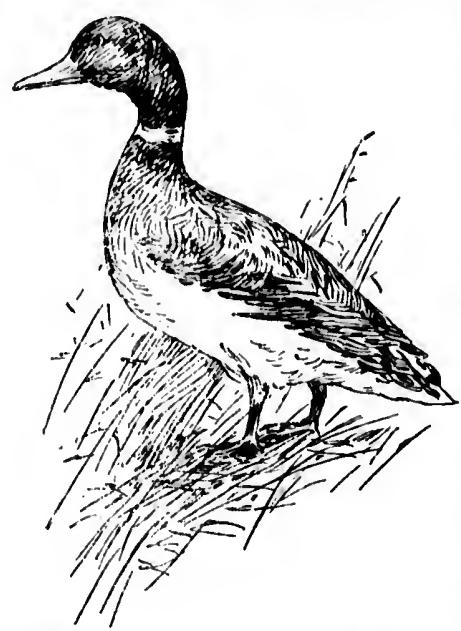
game, at many points as plentiful asthey wore when only the bardy royageurs and the? pioneers of olden lays invaded their smetuarjes. Upon the main, or "Transcontinental," line there are several places be. tweendlontreil and Ottnwn City-St. Anne de Bellevue, Calumet, Montel sllo, Pointe dı Cheme, Papineauville and Buckingham - neirr all of which good fishing is obtainable, and back of the latter places are both good fishing and good hunting for large and small game. The Lievre River, which empties into the Ottuwa at Buckingham, is a splendid flshing and camoeing stream and flows though a great game country. Beyond Ottawa City, the first promising stopping-place is the town of Amprior, situated upon an expansion of the Ottawa known as Lac des Chats, and distant from Carleton Junction about twenty-six miles.

The bass fishing in Lac des Chats is fully equal to the average waters in Ontario, which is saying not a little. Upon the shores are many attraetive spots for a camp; but the best of all, and the one most frequenterl by camping and picnic parties, is at the beantiful Chats Rapids, where fine sport can be had with the bass, and a week or so be pleasantly spent under canvas. Boats, guides and bait can be secured at Arnprior. The most reliable baits are live minnows and worms. Trolling with spoons is also a sure method, and other artificial lures ought to do good service. 
Up the Malnwask River the huuting is rery good. Bear, deer and smnll game ubound, and the flshing is excellent. Expertenced guides can be secured nt Arnprior, und there is no trouble in getting canoes.

The town of Pembroke should be the objective point for many of those who soek trout lishing. It is situated upon Alumette Lake, an enlargement of the ottawa River, and is some seventy-cight miles from Carleton .lunction, and alirectly upon the line of milway. The town contains abont inow) inhabitants and offers good hotel necommodntion. There ure plonty of boats and wagons to be hired nt $n$ modornte out lny, and it is the contre of one of the best trout regions in Americn: and there are nlso sovernl places within ensy roich where copital black bass flshing is tho rule.

The entire conntry herenbouts is intersected with many streans of various sizes, all plentifuliy stocked with tront, the sire of the flsh varying in proportion to the volume of water where they ure found. On the Quebes sicle of the Ottawn Rivel, the Laurentian range of mountains forms the bank, and every stream which comrses down their slopes (and their name is legion) is stocked with trout. A detniled list of them would be usoless, as the nngion emonot go astray ; full information regarding them, however, wiil be found in the pmmpliet issued by the Canndian Pacific Railway Company devoted sipecially to Quebec. On the Ontario side and within a fow miles of Pembroke, are a half-dozen waters which aftord first-lute flshing.

Within six miles me three good waters, in any of which an avernge angler (an take as many gond fish in a clny as he needs.

Within twenty-five miles of the town, and out in Chichester township are a great many lakes in which large catches can be malls. Of these fish too much cannot be said; they are the gamest of the game, and a marked peculiarity about them is their uniformity in size. Anong a whole dny's catch three-fourths of the fish would weigh a pound apiece, very few running below that weight, and few or none exceeding $n$ pound and a half.

Fifteen miles below the town are the Paquette Rapids, than $\mathrm{wl}^{\circ} \mathrm{ch}$ there is no flner spot for camping. To reach this water necessitates a pleasant drive, but the fishing is of the best.

A particularly good lake, distant from Pembroke twenty miles, can be reached hy steamer, and also the mouth of Deep River, both of these waters furnishing good sport. Another lake is sitnated upon n small mountain, within easy driving distance, and from it splendid trout can be taken in good numbers, the fish running from one to two and $n$ half pounds. It is a rare occurrence to take a fish weighing less than a pound in the lake. To rench it, one has to put in a bit of uphill tramping, but only long enongh to thoroughly extend the muscles and fit a man for a grand day's work. A peculiarity about the trout in this and some other neighboring waters is that they appear to be of three different varieties, though the difference is simply a matter of color and markings

Perhaps the first fish canght will be a fine specimen of the ordinary brook trout, resplendent with the famous jewelled 
regalia which has so often been sung and witten of. The soevond tish may prove to be a paleg-tinted, heaving-male follow, game to the bickbons, and swift nowl strong, but lacking the besusty of number onc. The angley will to a cortainty eye

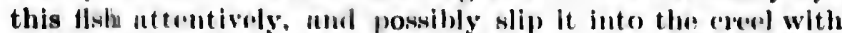
the renuak. "That's the querrest looking trout l've seren for' some time," and he will east again, hoping to tuko another.

The fly will kiss the water, and lo! there is a suditen lightring glean and a florer strain that makes the rol bow in neknowledgment, and tho real screnm a surprised protest, while thr bloorl courses through one's veins in swift response to the challenge of a real out-mul-out flybter. The swirling battle gors on-the maldened rushes grow shorter and wenker, tha roel antiously devours fout hy foot of the silken tethes, and presently the net sinks helow a royal prize; and he rolls over, with a desparing effort, the current flashes with a glomu of brightest gold, and you huve an example of what is styled in thre vicinity " "golden trout." Swift, valiant chanpions of the flood are they, looking as though they had heen gildon all owere thoil lower parts with a tint that rivals the splondor of the lazy gold-flsh of glass-globe notoriety ; and never did noblere cluarry test the spring of a rocl. Such we the trout of this momitain lake.

To refer again to the streans upon the Quebec side, Oiscau Creok desseves more than a passiag notice. The fishing is particalarly good, the cateh weighing from a fuarter of a pound cach up to a pound and a half. In oriter to fish this creek proporly, the mugler must go prepared to wale, and the wnter will be foumcl clear of obstructions and the bottom safe, with no trencherous spots to entrap the foet. Betwern Pembroke and the town of Mattawa, ninety-four miles listant, are dozens of streams, all well stocked with trout, and soveral of them boing also excellent for bass, especially at Petewnwa, eleven milis from Peubroke, and also at (haalk River, nine miles further along the line. Inside of this limit several very good trout streans ne crossed by the track. On the Quebec side arr numerous piver's which can be followed to their headwaters, and cano trips occupying from a fow days to $n$ few weeks marle in alunost every direetion.

One of the best ereeks in the district is' Bissett's, crossed by the Canalian Pacitic line, and distant from Pembroke sixty miles. It is wide and open, with safe botton all the way across for wading; and some of the handsomest tront ever hooked in this section of country have been killed on' this water. The fish are not phenomenally large, but as a general thing they run very even in size, the avernge being from ten to twelve inches in length. Good sport can be enjoyed here.

Half an hour's run from Bissett's is Deux Rivièes, or Two Rivers station. There is plenty of game in this vicinity, especially on the east side of the Ottawn River, including moose, red deer, and bear; it is also a good place for tront fishing.

Back of Caughwana Lake, thirty-five miles from Denx Rivières, is an excellent spot for moose and beur, and trout weighing from two to three pounds abound.

Near here, in Ontario, is Algonguin Park, a great forest and game reservation established hy the Oatario Government, 
But enemgh has ben mentioned to give a gombl rough ides of the grent resoures of this section of emutry in the mitter of fishing.

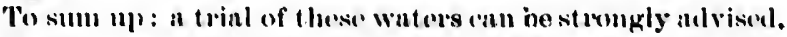
as the pesult will eomvine nny angler that this is an excollent comutry for trout flshing.

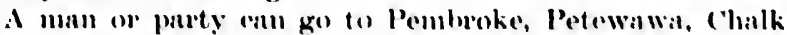
River, Moor Lakke, or Denx Rivières, enuiphed with their fincst tackle, and flucl (reely opportunity for using their treisures. They cun go with their best rods, choiecest lines, dealliest flies, and favorite perels, and fhed almulant sport: and they

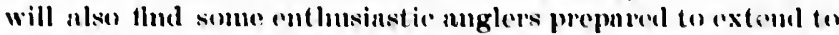
them the riphth-hand of followship in the crenft, and soe that visitors onjoy themselves: for there is mo med for joulonsy of a rivnl's performune on such richly sterkerl wnters, of in

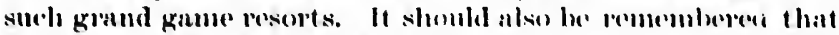

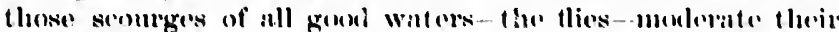
at talcks about . Iuly lst and alle not noticed at all afte.e the end of luly.

As a gime commley, this territory will not be fomml inforion

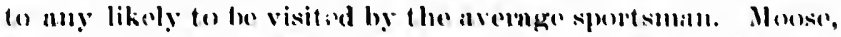
rarilom, and alk, are entirely proterted hy law in Ontalrio,

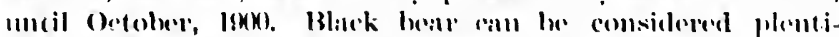

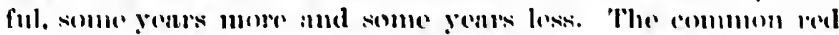

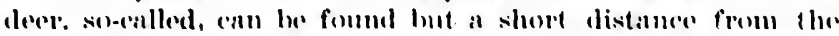
line of the milway, benx Rivicers and neighboring stations heing exereptionally promising points : but the best plan for in

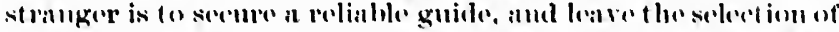

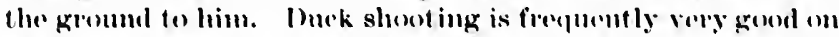
the larger lakes: I 11 the spereial mexit of this part of the comutey is the aloumbunes of forest grome. Those who visit it rin depend upon lawing plenty of phinkess at derer, within all likelihoul a shot or two at benr. anul motred grouso in abundance.

\section{THE MATTAWA RIVER, ITS HEADWATFRS, TEMISKAMING ANO TRE UPPER OTTAWA.}

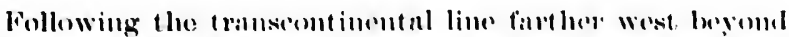
Penturoke and the wateps referend lo, the next important station for sportsmen is the town of Mattawa, situated at the

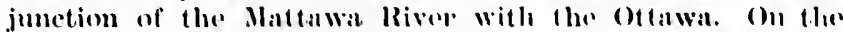
farther side of the lattor strean the Iambentian Montantios torminate in nu immense blutr.

The town of Mnt tawa (a name burnwed from the Lodians. nul signifying "The Morting Place") is ono of the best points on that portion of the line to tlt ont for an estembel shooting or flshing exeursion. 'The hotel necommolntion there is good. and prices are low for lomel, or guides and bouts. It is a

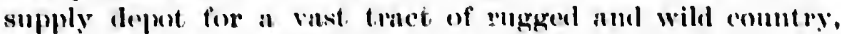

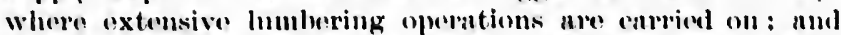
wherever you find humbermen you an also depend upou finding a plentiful supply of their fannous "river lerats," and the ecpially funous canems. This lubls good of Matiawn. and well-informed guides cun likewise he securiul. 
The upper country is noted for big game, moose being plentiful, and deer everywhere. Black bears are liable to show at any time, and moving through the woods, you will flush ruffed grouse in numbers-singly, by twos and threes, and whole coveys of from nine to fifteen birds. Wing shooting, owing to the nature of the cover, is very difficult.

The trip up the Mattawa by canoe is as follows, it being understood that there is plenty of game on either side of the river, and all about the lakes to be mentioned as its headwaters. Going up stream, of course, necessitates considerable work, and this ronte is described for those who want to be most of their time in their canoe and enjoy a trip up and back. The easiest way to do the Mattawa is to take the canoe by rail to Lac du Talon, which is crossed by the Canadian Pacific Railway at Rutherglen station, from which one can work up and down the river. Your guide will lay out the route, and decide upon where to pitch the tent if shooting is the primary object.

If you are especially bent upon fishing, or are too early for the shooting season, you can secure guides at Mattawa, and start up stream prepared to enjoy fine scenery and work with the rod that will not prove disappointing.

Leaving the town and paddling up the river, the scenic effect is like a long panorama of pleasing views, changing at every turn; and each stretch of glancing water and towering rocky bank is apparently fairer than the last, until, about a mile and a half from the starting point, the first portage is reached at McCool's mills. This portage is about 100 yards long, and then comes the beautiful sheet of water called Champlain Lake, some five miles long and varying in width from a quater to a half mile.

The shores of this lake are very pretty and well wooded, with numerous moss-covered rocky terraces, which afford excellent sites for a party to pitch their canvas. There are plenty of fine lunge and buss, which take the troll readily ; while in any of the countless coves and bays the stickler for the rod can find scope for his ambition with bass weighing from one to five pounds.

Passing on up the lake, a roar of water is heard, and presently we reach La Rose Rapids. The Amable du Fond River, which is the outlet of a small chain of waters, among which are Crooked, Manitoulin, Smith's and Tee Lakes, pours its rapid current into the Mattawa at the head of these rapids. The river is well worth exploring, as in the lakes mentioned there is capital fishing. To pass La Rose Rapids necessitates a portage of about a quarter of a mile; then the course is straight against a sharp current until some small rapids are reached at the foot of Birch Lake. These are but trifiing obstacles, and the next point is what is called "The Needles." Here the detour is completed and the Mattawa is reached again. A goodly sized brook comes tumbling down the deep slope fron the mountains, and the angler will do well to keep this stream in mind, for it drains several small mountain lakes heavily stocked with speckled trout of good size.

Passing on up the river, Nature assumes a grander aspect, the hanks reaching upward higher and higher, until in many places they form walls of sheer rock from 100 to 200 feet high. 
se being liable to ods, yon twos and s. Wing fficult.

, it being de of the its headisiderable ant to be and loack. canoe by an Pacific work up oute, and e primary

oarly for tava, and vork with

the scenic anging at towering 1, about a portage is 100 yards led ChamIth from a

11 wooded, ch afford There are readily ; tickler for weighing and prend River, ng which pours its se rapids. nentioned essitates a s straight eached at acles, and Here the gain. A ope from is stream s heavily

r aspect, in many eet high.
Parause Rapids and the Little Purause demand another portage; then struight paddling again to the Mill Rush; another short portage, and thence go paddling through Eel Lake for a couple of miles; then unother mile of the river proper, the scenery being, if anything, move pleasing than that already passed, and Tulon Chute is reached. A portage of nearly 300 yards is followed by about a mile of fast water, after which the work at the paddles cav be slackened, for the voyageur has reached Lac du Talon, famed among the lumbernen for its mighty limge and bass.

This is one of a regular network of small lakes which form the headwaters of the Mattawa; and verily this network is on that will entangle the angler's heart, for in one and all of its channels are splendid fish. Countless unnamed small streams and rivulets contribute their currents to feed these lakes, and speckled tront abound wherever the water is deep enough to cover them.

If the Ottawa River, which is a succession of long reaches and lakes with intervening rapids, is followed north of Mattawa, it will be found to traverse a wild region very similar in general appearance, and with game as plentiful as mentioned in reference to the Mattawa. Each of the unnamed and practically unknown streams and lakes will be found to contain plenty of trout, ranging in size from fingerlings up to great fish, accorling to the volume of the water they inhabit. There is particularly good fishing in. Antoine creek, a few miles from Mattawa. A conoe trip in this direction would prove very enjoyable at certain seasons of the year, but when the logs are coming down in the midsummer and late fall some difficulty may be experienced unless one is aceompanied by capable voyagem's.

However, the first stige of the jomney is usmally mate by rail from Mattawa up the Ottawa. The Lake Temiskaming branch of the Canadian Pacific Railway follows the left bank of the river from Mattawa to Temiskaming at the foot of lake Temiskaming, where it branches off to Kippewa on Lake Kippewa. By this route one reaches a country of moose, caribou and bear, and every feeder of the Ottawa contains brook trout. The Jocko River, which joins the Ottawa at Lumsden, is a good trout stream, and excellent sport can be obtained at Beanchene and Boistranc Lakes. Lake Temiskaming (Indian for "deep and shallow water"), an expansion of the Ottawa some seventy-five miles long containing black bass, and surrounded by forest levels of exceedingly rich land, occupied at present by lumbermen and game, but destined shootly to attrict numerous scttlers, cin be traversed either by canoc or steamer's, a fine line having been established, which runs in connection with the trains. At Teniskaming station, where there is a really excellent modern hotel, Baie des Peres, Haileybury and old Fort Temiskaming, an ancient Hudson's Bay Co.'s post, the sportsman ean find comfortable quarters from which expeditions can be made, and at the hirst named place parties can be fully outfitted and supplied witl guides, etc. On the northern shores of Lake Temiskaming caribou ure to be found in herds. Beyond Lake Temiskaming, in a great game region, the waterways lead in all directions. Should one wish to go to Temiskuming the peerless, with its 
1400 islands and limpid waters teeming with game fish, he will portage from Haileybury and canoe up the Montreal River and through Lady Evelyn and Diamond Lakes to Temagaming, and via the northeast arm and the Rabbit Lakes back toTemiskaming. The most enjoyable canoe trip imaginable is found here-full information about which is given in a special booklet devoted to Temagaming. If the sportsman wishes to go to James Bay, from the head of the lake, Lac des Quinze can be reached by good wagon-roads; from the latter lake he can go by the lumber company's "alligators" to the end of the deep bay where the Lonely River begins and which can be ascended to the first falls. On this road' there are few portages and they are kept in admirable order, while five-sixths of the journey is over splendid lakes, very well stocked with fish.

It takes about three weeks to go from Lake Temiskaming to James Bay when the beauty of the scenery and the abundance of fish and game do not detain the traveller longer on the way.

If, instead of going to James Bay, one wishes to proceed towards the splendid territories in the northeast, he can go from Lac des Quinze in an easterly direction by the "alligators " already mentioned to the sontheastern extremity of the magnificent Iake Expanse, called also Onanaouais. From this lake there is a choice of portages either by the river Ouanaouais or by the Ottawa to Grand Lac Victoria, so remarkable for the peculiarity of its shape, the quantity and the excellence of its fish, and the surprising number of deer, moose and bears that are to be found near it. On this journey there are more portages than on the road to James Bay, but they are easy and well-beaten, while along them are several lumbering establishments where a fresh supply of provisions can be obtained. From Grand Lac Victoria, the line of the Canadian Pacific can be reached again by going down through a series of lakes and rivers by which he can canoe down the Lievre and reach the rail way at Buckingham, or the St. Maurice, coming out at Three Rivers, or continue on to Lake St. John and return to Quebec by rail. These routes offer glorious trips by canoes, which furnish themes for many a tale of moose and bear and wolf, of struggles with hardfighting tront and bass, of nights in the primeval forest, of beds of sapin, and \& thousand and one other things that go to make the life of a woodland wanderer delightful.

Lake Kippewa lies directly to the east of Temiskaming, from which it is reached by the short line of railway which follows up the rapid waters of Gordon Creek. Kippewa is dotted with innumerable islands, on some of which are lovely lakelets, and its arms spread out like the tentacles of a huge octopus in many directions, giving it a coast line of about 600 miles. Steamers make trips in different directions which reveal the splendors of these waters whose intricacies are suggested by its Indian appellation, which means " hiding place." There is hotel accommodation at the village of Kippewa, where the tourist can also hire guides, canoes and camping outfit. Kippewa gives a bewildering choice of canoe routes-one by the Maganasipi to Deux Rivières, another by the DuMoine to Des Joachims, each occupying from eight to ten days, a third by Ostaboining Lake and Fraser River to 
, he will

al River gaming, oTemisis found I booklet to go to can be lake he the end ins and ad' there er, while ery well

skaming e abundron the

proceed e can go "alligaty of the s. From he river ia, so retity and $r$ of deer, On this to James them ale upply of oria, the by going he can ghaul, or ine on to se rontes or many th hardforest, of that go

kanning, ty which ppewa is re lovely f a huge bout 600 s which cies are " hiding llage of oes and of canoe ther by eight to River to
Quinze Bay and the head of Lake Temiskaming, and thence by steamer-a fortnight's outing, another via North River, Birch Lake, Cascakanan Lake, thence hy Ross Lake to Lake Expanse and down the Ottawa to Lake Teniskaming, which would occupy about three weeks. These trips could be multiplied indefinitely and some would take from a few days to a few weeks, but the whole summer could be passed in these delightful solitudes with scarcely a duplication of route.

$A$ lover of the canoe, who prefers to take his own craft with him, can visit the town of North Bay, situated on Lake Nipissing, and distant from Mattawa forty-six miles, being also on the transcontinental line of the Canadian Pacific Railway.

From North Bay he can, if so inclined, first explore a portion of the fine Lake Nipissing, and then send his canoe by waggon to Trout Lake, some four miles away, and reached by an excellent road. This lake is the largest of the headwaters of the Mattawa, being about twelve miles long. From it the route by canoe is the same as was followed in bygone times by the voyageurs of the Hudson's Bay Company, i.e., from Trout Lake to Turtle Lake; thence a trifling portage enables you to reach Pine Lake, from which a portage of a quarter of a mile completes the journey to Lac du Talon, already referred to, whence the trip on the Mattawa can be reversed until the Otta wa is reached; and once that stream is gained, the voyageur can decide for himself where the trip) shall be finished, for he is upon that magnificent highway of waters that ends with the mighty St. Lawrence.

\section{LAKE NIPISSING AND TROUT LAKE.}

On the shores of Lake Nipissing is the bustling little town of North Bay. The lake is a magnificent sheet of water, some thirty miles wide and eighty long, offering every facility for sailing, bathing or fishing. There is plenty of hotel room, from $\$ 1$ per day upwards, and the town is built close to the beach, the several hotels being about 200 yards from the water.

Below the village a long pier runs out 150 yards or more, for the accommodation of the steamers; and, early in the spring from this point of vantage big catches of pike, bass and pickerel are made daily. The method used is " whipping" with a rod and spoon or with a fish's eye for bait; but there are plenty of minnows to be taken with proper tackle; and with live bait, or any of the good imitations, great catches could be made without going farther than the end of the wharf. There are good boats, including two steam yachts and sail boats, available; and by rowing towards the Indian reservation, a pleasant trip and a good catch are assured. The list of fish includes bass, pike, pickerel and lunge, and heavy ones of each variety will probably be taken during an afternoon's trolling. But a visitor must remember that sport is sometimes uncertain upon all large lakes, and he should not despair if he fails to land a big string at the first attempt. This will also apply to Trout Lake or to any other water of equal size. But the chances, especially on Nipissing, amount to almost a certainty in favor of success, and, unless the water is too rough, he will return with a fine lot of big ones. 
As a shooting ground the Nipissing country ranks very high. There nre any number of deer and ruffed grouse all nround the lake, quite $a$ few moose, caribon and bear, and upon what is known as the "long nrm" of Nipissing, good duck shooting can be had in the fall. The district about Callander, and the very best portions of the Muskokn deer country, are close at hand, and those of Parry Sound lie between this lake and the Georgian Bay, and they are among the best known.

One of the best points on the Nipissing, and reached direct by the Canadian Pacific Railway, is the country around Sturgeon River, distant from North Bay twenty-three miles, and hunting parties during several years pust have returned home laden with the spoils of the chase.

Some four miles inland from Nipissing is the beautiful Trout Lake, of which so much has been written during the past few years. 'To a camping party this lake offers attractions of the highest order, and there are two or three houses upon the shore where a few visitors can be comfortably provided for, and where a sterm launch and half a dozen excellent skiffs are kept for hire. Trout Lake is a picture that once seen will never be forgotten. Numerous islands of all sizes, from half au acre to nearly a hundred, make portions of it appear like so many separnte channels, and form a combiracion of lovliness that is not surpassed by any lake in Canada. Surrounding this water is a rugged, rocky, lonely wild, with great hills and deep $r+v i n e s$, alike donsely clad with towering evergreens, and through their shadowed aisles runs many a good tront stream.

Fishing in the lake is a thing to be remembered. Deep in its icy depths are great big salmon trout, and for these an extra weight must be put on the troll.

But one need not go "three thousand leagues under the sea" to have sport, for, with ordinary tackle, bass and pickerel of good size can readily be taken; and now and again a monster lunge will test the angler's quality. One of thirty-five pounds weight was hooked by a lady, and successfully landed after a hard fight.

If a man spends a week at Trout lake and comes away dissatisfied with either the fishing or the scenery of that richly endowed spot, lie is indeed hard to please.

A guide and boat can be secured on the spot, and, starting from the head of the lake, the visitor is pulled away down for. a couple of miles ere it is time to cast out the trolls.

Each fisherman should have a couple of lines for this reason : some few yards from the rocky evergreen-clad shore a sort of shelf of rocks runs out ten or twelve feet below the surface. It can be distinctly seen, and the object is to keep the boat as near as possible above its outside iimit. Looking down through the clear water, you can trace the extreme edge of this ledge, and immediately outside of it is a black abyss of great depth. The two lines are worked in this way: one should be as long is possible, and have enough sinker above the troll to keep it at the depth of this shelf of rock, the other and shorter line requiring nothing but the ordinary spoon hook.

Following this method, some heavy fish should be taken, the short line keeping the angler well occupied playing bass and pickerel, with a very good chance of hooking a big lunge. 
Passing on down the lake the scenery is extremely beantiful, and one realizes how thoroughly attructive is this wilderness. Presently a round openting in the wall of evergreens is noticed, and a closer inspection reveals Short Portnge, a few yards long, which leads into Four Mile Bay. We tuke a peep through, and note how pretty the survoundings are; then go down the lake towards Big Camp Islund, seven miles from the starting point, passing seceral very pretty little islands on the way. Many have pitched their canvas upon the big island, and all mite in praise of the resort. A climb upon some of the great rocks, where the moss forms " resting-place fit $\mathrm{f}(\mathrm{r}$ a king, gives plensant relief from the confinement of the skiff, and one can lie in dreamy comfort, and recilly find that peaceful rest which is such $u$ delusion upon muty holiday trips. Fiarer spot could not be chosen for $n$ week or so in eaup, and in a short time the attractions of this neighborhool will be letter understood.

Turtle Lake is connected with this water, and the fishing there is something to be remembered: while in its outlet, Lost River, the bass fishing is unsurpassed. Many big eatches made on the last mentioned are on record, some of the bass ruuning over three pounds, and quite willing to be caught at the rate of fifteen an hom.

A peculiarity of Trout Lake is a wonderful echo, which is best tested from a point on the water about two miles above Big Camp Island, especially on a calm evening. Under such conditions the slightest sound is repeated with startling distinctness muny times over, and testing the mocking voice of the distant hills is a iavorite amusement with those enjoying a paddle by moonlight upon this lovely water. A shiu'l ary or lond whistle is answered at once from the lofty hills on either side with marvelous precision ; then there will be a few seconds of silence, and a musical re-echo comes floating back, to be repeated again and again from hill after hill, and point after point, softer and sweeter as it slowly dies away, until it is finally lost in a whisper, faint and far, from the grent forested height that marks the head of the lake.

Shooting in the immediate neighborhood is always good. Bears frequently appear upon the shores; to see deer swimming from the mainland to one or other of the islands is a common occurrence; caribon are met with and moose have always harbored about the beaver meadows and in the lensely wooded stretch of lowland near the foot of the lake. A couple of Toronto gentlemen canght a very young moose there a few seasons ago, and released it again after it hat been admired by the rest of the party. 


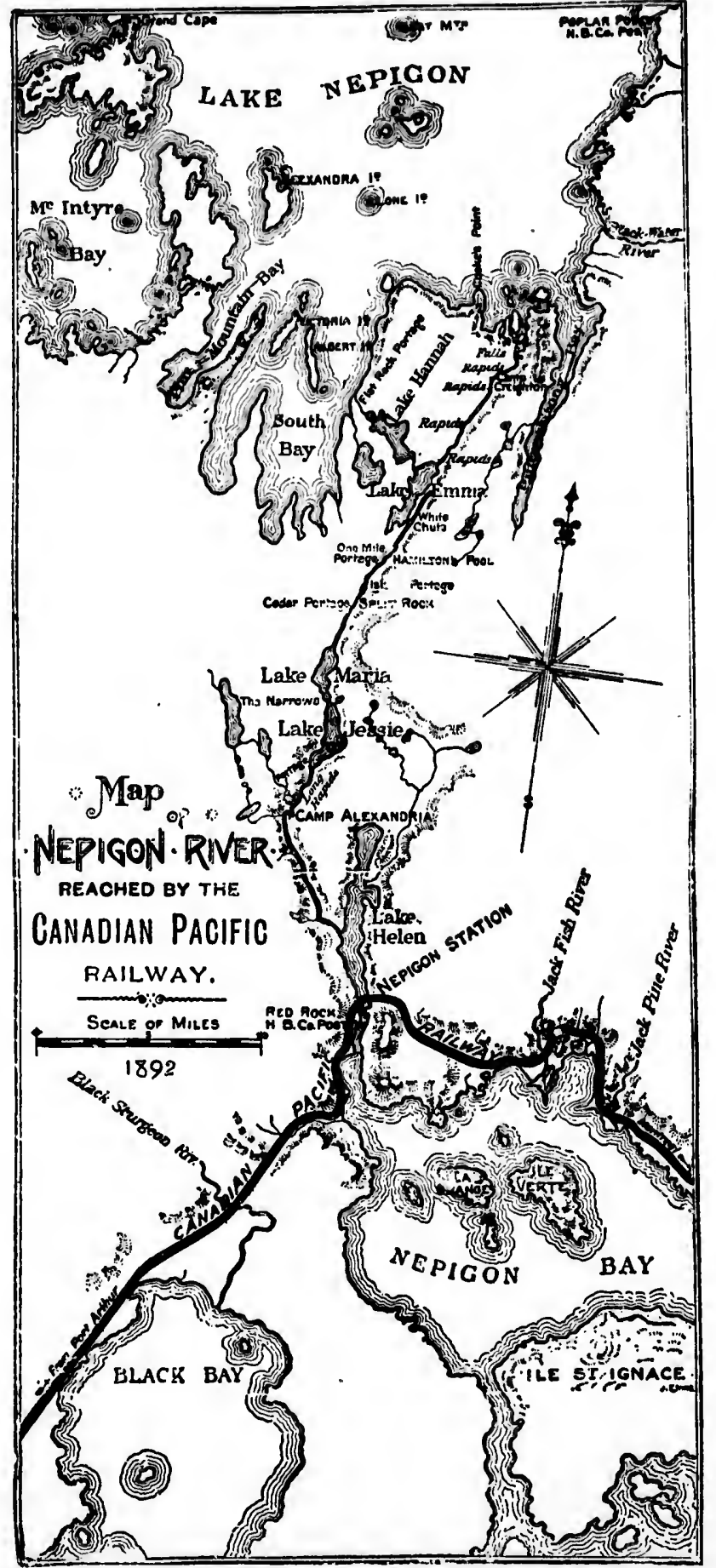

FR

des

reg

vor.

ren

who

the

in $t$

in $t$

are

suck

Nea

the

grot

will

fron

drai

the

kaug

rare

abot

good

the

has :

it is

can 1

lising

trou

Blac

Cree

sever

these

be re

be pr

mod:

in th

or be

desir

I

to fo

ago, of $\mathrm{tr}$

diffic

Wha

leadi:

many

to ar

made

Rive

these conve 


\section{FROM STUROEON FALLS TO FORT WILLIAM AND LAKE OF THE WOODS, INCLUDINO THE FAMOUS NEPIOON AND STEEL RIVERS, ETC.}

In following the transcontinental line from the portion just described to Fort William, the route traverses a good game region, rough and wild in the extreme, and crosses some of the vory finest trout streums on the continent, including the worldrenowned Nepigon River and Iake, the dream alike of anglers who have and have not cast $a$ line in its rushing fiood, or had their best efforts taxed by the jewelled leviuthans that abound in that incomparable water. Many of the rivers und brooks in this section, or the numerous lakes, great and small, which are seen from the cal windows, have never been fished, but such as have been tried have richly rewnrded the experinent. Near Sudbury some fair lake fishing is obtainable, and the adjacent country is a good one for black bear and grouse. In traversing the north shore of Lake Superiol you will cross, among others, the Wahnapitateping River, flowing from Lake Metagama into Georgian Bay ; the Onaping River, draining the lake of that name; Spanish River; Mississaga, the outlet of Winibegon and Ground Hog Lakes; the Apishkaugama, Michipicoten and the Steel Rivers, trout streams of rare merit. The Magpie, White and the Little Pic Rivers also abound in trout of good size, White River being perhaps as good as any of the extensive list. Steel River offers some of the choicest trout fishing available outside of Nepigon. It has several small falls and rapids and deep pools, and, in fact, it is just the stream an angler loves, and wonderful citches can be made either hy following it upward or near its mouth, lising either flies, worms, minnow, or artificial lures. Other trout-haunted tributaries of this north shore are the Mink, Black, Maggot, Gravel, Cypress, Prairie, Jack Pine, Trout Creek, Wolfe, McKenzie, and Current Rivers, and there are several others within easy reach of the railway. In all of these trout are numerous, and the great majority of them can be readily waded. Of course, in fishing such waters one must be prepared to live under canvas or put up with poor accommodation; but that only adds to the enjoyment of a holiday in this lone, romantic land, and more attractive surroundings or better fishing than will surely be found there no man can desire.

The Railway Company, desirous of doing all in its power. to further the interests of sportsmen, decided, some years ago, to render several of the good bnt almost unfished rivers of this district more accessible, and also to decrease the difficulty of fishing that exceptionally good water, the Steel. What was most urgently required was a system of trails leading direct to the fishing, for the woorls and covers about many of the best reaches of fast watel were almost impassable to any but experienced woodsmen. Trails were accordingly made upon the Steel River, Pruirie River, Black River, Gravel River and Jack Pine River, and it must be remembered that these are the choice of the whole extensive list. A few remarks conveying hints for general guidance to each will be useful. 
Michipicoten. 'To fish this river you get off at Missanahie station ant eross Dog Lake in a stenu-lnunch, distance about ten miles, to Stony Portage, where the fishing sturts. Good flshing is to be had from this point to where the diver emptios into Lake Superior, " distance of about forty miles. The al'e large (up) to five und a half pounds) and gaune, the water rapid and lots of rom to cast a fly. The strenu has been very little fished. It probubly is very little inferion, if at all, to the Nepigon. Guides and canoes con be secured at Missanihie, without any clifflenlty if alvaner notice is given.

From Missimabie the tomist ath make the journey to Jaurs Bay -tho southern portion of Hulson's Bay. This is acromplished by eanoe. 'fluc river cannot he surpassed for' scenely. (iood fishing and shooting enn he hat. The jomney occupies from right to ten days from Missumabie to Moose Factory, the Huilson's Bay Company fort and hendyuarters of the Company in this part of the country. The return, which is against the strean, will take fifteen to eighteen days and ean be made either by the same ronte or by the Abittibi River to the upper Ottawa and Lake Temiskaning country reaching the railway again at Temiskmming.

White River. Fuirly good flshing is to be hat in this strealu. The railway follows the river from White River station to Montizambert. The fish are not very large, avernging fiom one to three and a half pounds in weight. In the proper sensom, i.e., firom August 1st to September listh, the fish are plentiful. The alvantage of this stream is that $i c$ can be fished withont guides, as at no point is it more than a quarter of a mile from the ralway between the abovementioned points.

Peninsula. Station close to the shore of Lake Superior. Gool tront fishing can be had along the shore of the lake lesween this point and Polt Coldwell station; also in Port Munro stream, four niles west of Peninsus., and in the Mink River, abont eight miles west of Peninsula. Canoes eamot be used in either of these streans. Plenty of fish to bo had, and of a large size. There is a hotel at Pesinsula, where the traveller (ail get a good elean bed, provided he does not wish to camp out.

Middleton, First-rate fishing to be had in Lake Superior along the rocks at this point. It is also the station to get off at for any one desiring to fish the Little Pic River. sitnated two miles east. Good fishing to be had in this stremin. Indians are always encimped at the mouth of it, and they can be engagen at any time to take the fisherman ul the river. The only drawback to the river is that, for four or five days after ruin, the water is so discolored that the fish camot see a fly, which makes the fishing very uncertain ; however, the fisherman can "lways depend upon having good sport in Iake Superior.

Prairie River. Situnted two miles east of Steel Lake siding. The Commany has had a trail cut out along this river, which starts about 500 feet west of where the river is crossed by the railway, anl runs in a northerly direction for about four miles, where it strikes the river at the heal of the rapid water. Fishemen from this point can wade clown the rapids, where good fishing is to be had all along. The trail is cut quite close to the river, and can be easily reached from any point. Good fishing can be had in this water after the middle of Jume; but it is particularly good from August 1st to 
stannbie so nbout Goot enupties Tho.

e wnter as been f ut all, Missn 11-

aney to This is ssed for journey o Moose yuarter's returu, een days Abittibi ; country

1 in this te: River , nverngIn the 15th, the hnt : c cull re than a a aloove-

Superior. the lake? o in Port the Mink as crinnot - had, nnel etraveller (ain) out. Superior to get off unted two dinns are e cugageal The only fter rain, ly, which rinau call rior.

teel Lake this river', is crossed for about the rapid he rapids, rail is cut from ally he middle st lst to
September 16th, fish running in welght from olle-lialf to thies? pounds.

Steel River. Get off at Juck Wish stution. A truil, starting about a quarter of a mile enst of Jack Fish, bus been cut through to Clearwater Lake, a distunce of alout two und $n$ haif miles, and the portage between Clenrwater und Momitnis inke(the headwaters of Steel River), " nile in length, has been brusherl out and put in good order. A trail has been eut on the west side of the River from Mouritain Lake to the foet of Big Blutf nt Telford's Pool,at which point the river can be wuded nt low water. On the east side a truil has been cut froul Mountain Lake to the foot of rapid water. A truil has ulso been cut from the irou railway bridge to the basin and head of the rupits at the moutl of the river. A canoe cun now be taken in by way of Cleawater Iake and down the river to. Jack Fish stution without difficulty. Tho portuges, though long, are goot. 'The fishing in this river is good from the time the ice leaves until the midale of June, exeept imuediately after henvy ruins, when the water is too much diseolored for a liny or two. From the midelle of June until the 1st of Aurust good sport is to be had, though somewhat uncertain. From August 1st to September 15th the fishing eanuot be surpassed anywhere, the fish ranging in weight from two to six pouncls.

If the fisherman intends visiting the hendwater's of this river he should have guides with hin ; but capital sport ean be hul from the month of the river to the basin. If this papt of the river is flshed 110 guide will be required, and just us good sport can be had as in the upper stretches.

Black River. Situnted half a mile west of Blick River siding. The Company has had a trail cut, starting from the west side of the bridge over the liver, and ruming north for alowt four miles, to the head of the rapids. From this point fisherinen can wade down the river, where good sport is to be? had. The fish are plentiful, though not lnige ; nnything over two tud a half pounds in weight is rarely caught. It would well repay nnybody to visit this point, if only to see the falls, which are situated about a nile south of the brielge. A gomi trail leading to the falls starts from the line of railway about a mile west of Black River siding.

Gravel River. A trail has been ('ut fuom Gravel River station to the foot of the big falls on Gravel River, a distance of two niles, then down the river along the rupid water for about two and a half niles, then back to the stution. These: trails form a trinngle. The fishing in the river is gocol, particularly early in the season and in the fall, though soutewhat uncertain. Fish range in weight from one and a late to four pounds. Good lfishing is also to be had from the roeks along the lake shore. This is a most clesirable point for parties who wish to enjoy good fishing without the expense of guieles. There is a good camping ground nenr the station, withiu ansy reach of both the lake and the river fishing. The scenery lere: is particularly fine.

Jack Pine River. One-fourth of a mile east of Mazokann station. A trail, starting from Mazokama station has been cut north along this river for four miles to the head of the rapid water. Large fish are taken in this river from the time the ice leaves until the middle of June, except durirg very high water. From the midelle of June until August 15th lirge 
numlicrs of fish can be tuken, though sonewhat small in size: the fishermin can always look for three or four large flsh, and not be disnppointed, during $a$ day on the river. From August 15th until September 15th the fish nre plentiful and lurge, avernging in weight from one und a half to five pounds.

Pearl River Station. Between Penrl River stution and Loon Lake sidling are a number of lakes, nmong them, I, a Lake, Bass Lake, and silver Lake, all within ensy rench from the ruilway, where enpitul bluck buss nul trout flshing is to be had.

The Nepigon. Most finmous of all the strenms of the north shore, however, is the benutiful Nepigon, and nobody going that fur should fuil to make the trip by conoe from its mouth to the parent lake nbove. It is now so well known that n minute deseription is entirely unnecessury. Enough has alrendy been written nbout its scenery and sport of fishing to fill severul volumes.

The Nepigon is some thirty-one miles long, and connects Lake Nepigon with Superior, its waters emptying Into Nepigon Bay. On n flshing day-for even Nepigon has its "off days," and occasionally gets the sulks-you will take veritable ginnts; glent trout of benuty and weight, that even the rankest enthusinst ne'er drenms of till he hus tried this strenm. Two-pounders, three-pounders, four, five-yea! and, by the unlying scales, eight-pounders are there rendy to spring upon the deadly fly und fight to the last gasp agninst your practised hand. The station for it is Nepigon, where will be found a comfortnble little hotel with nccommodntion for $n$ limited number.

On some days the fishing is fairly good from the railway bridge down to the mouth, particularly in the rapids; but to fish the river properly you must camp, and fortunntely there is no difficulty about obtaining guides (Indians) and canoes at Rell Rock, Nepigon, Ont., a Hudson's Bay Company's post. All necessaries for ordinary camping perties can also be obtained there. Intending visitors must bear in mind that a trip up the river means living under canvas, and govern themselves accordingly. Neccssities can be obtained on the spot: luxuries must be brought from the towns. There are many beautiful sites for a camp all tlong the river, and to say that it is a veritable nngler's paradise is quite within the mark. Trout scaling from two to five pounds can be realily taken on any of the best pools, and whitefish are plentiful and afford fine sport, rising eagerly at "gnat flies." Their mouths are as tender as wet paper, and a light hand must have hold of the rod to land them; but a two or three-pound whitefish is not to be despised, as he will fight bravely on the hook, and is wondrous toothsome on the platter.

The standard flies for Nepigon and adjacent waters are the " professor," "queen," "grizzly king," "Montreal," "Seth Green," "fairy," "shoemaker," " coachman," "silver doctor," "gray drake," "green drake," yellow, brown, black and grizzled "hackles," and "gnats" for the special benefit of the silvery whitefish. In addition to such of these as you may pin faith to, and others of your own particular fancy, it will he as well to take some artificial minnows and a few of the 
small in ur large r. From plentlful $f$ to flve

ion ind $\mathrm{m}, 1, \mathrm{o}^{-} \mathrm{t}$ ich from ing is to

lie north dy going s nouth " that a ugh loas ishing to

connects to Nepiits "off veritable ven the s stream. , by the ing upon practised found a l limited

railway ; but to ely there canoes at y's post. also be ind that d govern d on the there are nd to say he mark. taken on dd afford uths are bld of the sh is not $k$, and is doctor," and grizt of the you may $y$, it will $w$ of the good rubber bits along: for they come in very handy when tho fish rofuse a $\mathrm{Hy}$, and are npt to tompt big follows. Four fly-flsher may sneer at this, but let hin sneer, and take the baits just the samo. A fig for what the flsh rises to! So long as you play him fairly and well ufter he is once hooked. the sport is just the snme; and, moreover, if the true inwardness of the cenpture of some of the " monsters" was known, it might be that they fell to it grusshopper or oven a degraded " "rhunk of pork," while the fly-look was never opened.

The Nepigon falls 313 fert in its comese of thirty.one miles, and varies greatly in width, nareowing to ahout low) yards one mile from its mouth, hut bondening at other points into a noble st remu, Four lakes murk its comere, the first boing Lake Helen, only a mile from Rol Rock, the Canadian Pacifle crossing at its outlet. The eurrent at this outlet is very fast. Lake Holen extenils due north, and is some eight miles long by one wide. The river proper leaves this lake on the west side, and for six miles above it is broad and decp, with a moderate current, till the bend at ('amp Alexandria is renched. A quarter of a mile above are the long Rapicls, continuing for a couple of miles. These are aroided on the upward journey by paddling up a brook on the west side for thee guarters of a inile, and from thence portaging to the secoul lake, Lake Jessie, reached by a portage of a mile and a half. lake Jessie is three miles long and dotted with unmerous small islunds, and is separated from lake Maria by the tumbling nurows. The latter lake is two and a half miles long. From this lake to Cedar Portage, or Split Rock, the distance is a couple of miles, the portage being 250 yards long. A mile and a quas ter alowe is another portage over an island in the contre of the stremm, called Islund Portage, which is about fifty yards long; and three miles above it is One Mule Portane. At a trifle over a mile above the heal of this portage the stream dishes down in a foamy chute; and immediately above is Lake Emma, nearly four miles long. A narrow arm of the river extends beyond the White Chute, which the canoer will follow for about a nile, and then portage 230 yauds to Iake Emma. The distance betwen this lake and Lako Nepigon is only a fow miles; but the river is broken by four rapids not to be essayed by camoe. In order to avoid this, canoes turn aside at the north-west angle of Lake Emma, and follow a small stream, flowing from lake Hannah, for a cuarter of a mile, and thence onward for four miles to the head of Lake Hannah, where Flat liock Portage, one mile long, extencls to the shore of Lakk Nepigon.

This grand sheet of water measures some seventy miles in length by about fifty wide. It is stulled with a vast number of beautiful islands, and its coast line is so broken and inclented with coves and bays that it mensures goot 580 miles. To give an idea of the attractions of this lake, it may be mentionerl that the islands, great and suall, number nearly, if not quite, 1000, varying in size from eight miles in breadth down to mere rocky picturesque fingments. Uncounted streams, several of them navigable by canoes for a considerable distance, empty into the great reservoir, and make this lake a most attractive water for explorations. The principal feeder is the Kayosh or Gull River, at the sonthwest curve of the lake, at the month of which is situated "Poplar Lodge," a Hudson's Bay post. From the above brief summary some idea may be gleancl of the 
resonrces of Nepigon. No essential part of the outfit should be ounitted. for once started from Nepigon station you are in the willerness indeed; and take your veiling material and favorite "fly medicine" along, for you will need them. Like every other good water on the American continent, Nepigon has its winged pests; and, while the sport is such as to make you hold lightly their attacks, comfort is not to be overlooked. The Nepigon car be reached either by the Canadian Pacific Railway direct to icpigon station, or by one of the Canadian Pacific Railway's splendid lake steamers to Fort William, the tourist having the privilege of going by rail and returning by steamer, or vice versa.

A point to be remembered is that very large trout (genuine brook trout, salmo fontinalis) may be caught from the rocks along the lake shore at almost any point between Port Coldwell station and Mink Harbor, a reach of coast line of muny miles. Residents on Jack Fish Bay take all the trout they want by merely casting from the shore rocks with the rudest description of tackle; and there is good sport in hooking and playing a five, six, or seven-pounder in the ice-cold flood of " Big-seawater," the Gitche Gunee of the red man, upon whose mighty breast Hiawatha fought with the leviatb?ns who lurk below, as told in Longfellow's poetical story.

In the territory lying between the Nepigon and Fort Willian are a number of excellent waters, both for trout and bass. In two of them, Loon and Silver Lakes, black bass of great size are easily taken, as they rise freely to the fly, and the musual sight of a speckled trout and a black bass hooked on the sane cast has been witnessed at Loon Lake. This lake is the source of the Pearl River, and is well worth a visit, as is also Silver Lake, distant from it only three miles, and equally well stocked with the two fish mentioned. There are a number of trout streams in the neighborhood of Port Arthur and Fort William. The same choice of rail or steamer is of course offered, going or returning, as mentioned in connection with Nepigon, as Port Arthur and its sister town, Fort Willian, are the terminal points of the Canadian Pacific Railway's upp $\bullet$ lake steamer routes.

As shooting grounds, these broad tracts of forests, lakes and rocky bar'ens between Sudbury anci Fort William are worth attention. Blick bear, moose, caribon, and ruffed grouse are generally distributed; the best points being upon north shore of Superior proper; Jack Fish being perhaps, as good a centre of operations as any. But, as every sportsman knows, this implies knowledge of woodcratt and more or less work.

Westward from Fort William a wild broken country extends to the boundary line that divides the Province of Ontario from that of Manitoba. Like the region just referred to it his many lakes and streans; but the first worthy of special nitice is Wabigoon Lake, lying half.way between Fort Willian and Winnipeg. This Wabigoon (Indian for lily) Lake is a pretty sheet of water extending west and south about twenty miles in each direction by about three or four wide, with rough, rocky shores in places, and a few small islands. Lake trout, white fish, pike and pickerel abound in them, and may be canght with trolls. Beyond the Wabigoon Lakes are the upper and lower Maniton Lukes, fine stretches of water 
t should

1 are in iial and 1. Like Vepigon o make looked. Pacific anadial Villiam, turning

genuine e rocks 'oldwell y miles. vant by descripplaying Big-seamighty below.

id Fort ont and bass of fly, and hooked is lake it, as is equally are a Arthur ler is of nection 1, Fort Pacific

3, lakes im are ruffed $g$ upon iaps, as rtsman or less

country ince of eferred thy of en Fort y) Lake abont c wide, islands. $\mathrm{m}$, and kes are water

giving forty niles of steamboat navigation. Salmon and lake trout, white fish, and pickerel abound in then. A small stream connects the upper and lower Maniton Lakes with Rainy Lake, offering a now route to the Rainy River system of waters, which mark the international boundary between the Province of Ontario and the State of Minnesota. One can leave the train at Wabigoon station and descend the ontlet of Wabigom Lake to Rainy lake, and from there paddle either to Lake-of-the-Woods via Rainy River, or follow the international boundary eastward by way of Pigeon River to Lake Superior, reached at Grand Portage. Small but comfortable, steamers are placed on the route between Wabigoon and Rainy Lake-this being the Manitou district, which promises great derelopment of its mineral resources, and atecommodation is being provided en route which will be capital centres from which to work either for game, fish or gold.

Travelling westward from Wabigoon, Eagle River and Vermil!ion Lake are reached after a short run, and from here again the Rainy River and Lake-of-the-Woods may be reached by canoe, the route being by Eagle Iake, Vernillion Lake, and Huckleberry Lake and connecting streams. Very large lake trout can be taken in all of them, and maskinonge are numerous in the rivers linking them together. The next important lake is the magnificent Lake-of-the-Woods, one of the most beantiful waters in all Canada. It is so irregular in shape, and has so many islands and bays, that but a portion of it can be seen from any one point of view. As will be readily understood, experienced guides are necessary, if an attempt is mide to explore this maze of waters, but they can be easily secured. Lake-of-the-Woods sprawls .like a huge silver spider amid romant. surroundings of the most pleasing description ; and from it extend natural w.'ter highways for hundreds of miles east and west and north. Near its ontlet at Winnipeg River is the progressive town of Rat Portage, now a great mining centre, from which steamers ply regularly to Fort Frances on Rainy River, from which other streams run on Rainy Lake and the Seine River, where there are big and little game and capital fishing. Supplies can be procured at Rat Portage, For't Frances ind Mine Centre, the latter being a new town which has sprung into existence as a result of the rapid development of the gold areas in the vicinity. A point worth noting loy those fond of duck shooting is the English River, a tributary of the Winnipeg River, and distant about sixty miles north of Rat Portage. Very few men have shot here, but three guns killed as many duck in thirteen dnys' shooting on the English River as they ought to, and the owners of the guns travelled all the way from Toronto to do it. One of these sportsmen has shot at many of the best points in Manitoba and the Northwest, and made heavy bags, but he declares that the English River grounds are the best he ever tried.

To attempt to describe such a route in $a$ book of this nature is impossible. A glance at a map of Canada will reveal the extent of the great chain of waters referred to, and the sportsman can select from a hundred or so, long or ahort canoe trips the one that best suits his convenience. Upon these countless streams and lakes you can spend a delightful holiday, covering a few days, weeks, or an entire season if you will, tracing out the oldtime routes of the voyageurs famous in the history of 
the fur trate; for nuilions of dollars'-worth of fur's and peltries have been brought dcwn these glancing highwiys, and hundreds of feet have trodden the portages you will find by the way. You can paddle to Fort Alexumler, tracing the eourse of the Winnipeg River to Lake Wimnipeg, and thence sonth to the month of the Red River, and so to Selkirk, where rail is taken to Winnipeg; or, if you want more scope and prefer the far North, you can traverse the length of Lake Winnipeg to Mossy Point, and from there follow the Nelson River to Hudson Bay and Port Nelson and York Factory ; or you leave Lake Winnipeg by the boat route proper to York Factory, and follow the paths of the fur tralers. From York Fuctory you can coast ulong Hudson Bay to Fort (hurchill, and from there return to Lake Wimnipeg viat the ('hurehill River and another chain of lakes.

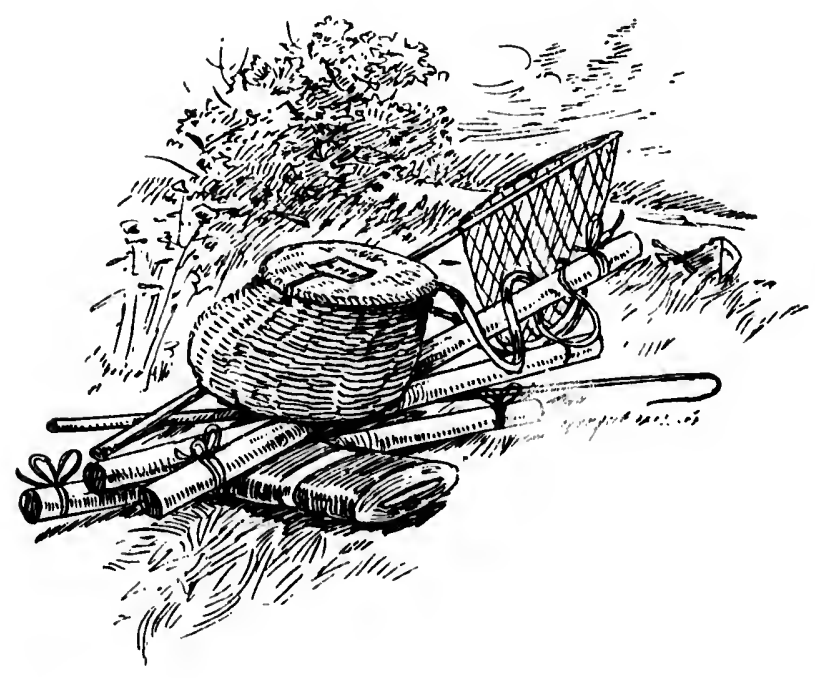


d peltries ays, and ll find by teing the ad thence k, where (') () and of Lake Nelson tory ; Or to York oul York 'hurchill, 'luturchill

\section{SAULT STE. MARIE, MICHIOAN, AND WISCONSIN.}

By the "Soo Line" of the Canadian Pacific Railway and the establishment of a direct route through the territory north of Lake Huron to the sistei cities of St. Paul and Minneapolis in Minnesota, more new territory is rendered easily accessible, and the disciple of lsatc Walton or Nimrod may with advantage devote considerable time to that tract of country between Sudbury and Sint Ste. Marie, there being virgin trout lakes and the best bass lakes and rivers to be foumd in its interior from any of the ralwiny stations. The Soo Branch forms part of that very important section of the Canadian Pacific ruilway which eomnects Boston with St. Paul and Minneapolis vin Montreal.

Leaving Sudbury, you find the same varied and pictmresque blendings of many colored rocks and rough forests marked here and there with silvery streams and lakes, the loveliness of the surroundings gradually improving until opposite Desbarats station a glimpse of Lake Huron and a portion of a cluster of 100 beantiful islets, which themselves form a part of the countless islands of the north shore of Lake Huron, is obtained. These islands are destined to become more popular than the Thousand Islands of the St. Lawrence, because of their cooler climate and greater variety and boldness of scenery. A pretty island can be bought from the Ontario Government for $\$ 5$ and upwards, of about, $\$ 5$ per aere. A Camping Club and Land Co. is being formed here on lines which should be acceptable to tourists and sportsmen. Write for special literature about Desbarats and Temagaming, and a pieturesque cottage built upon it for $\$ 250$ and upwarcls. The Canadian Pacifie Railway and four lines of steamers bring tourists' supplies, etc., to these islands. They are now quite accessible. They are only one hour by rail from "Soosans," as the two towns of Sault Ste. Narie are locally called. Sault Ste. Marie is a good outfitting place for camping parties. Desharats has a clean and comfortable country hotel. North of Desharats station three miles through the woods is Diamond Lake, an almost virgin t!nut lake, and about it are inany lakes which from the nature of the eountry, will remain well stocked with fish. The shooting is also good. The lakes, sechuded and yet accessible, would be admirable places for an anuual eamp. The surrounding lands could be bought cheiply from the Ontario Government and the fishing protected.

The Sault Ste. Maric, the great gateway between Lakes Superior and $H$ uron, has for years been a favorite resort with a large number of pleasure seekers. There is splendid accommodition for visitors, the hotels being conducted and equipped in first class style, and the many beautiful and interesting features of the spot are a guarantee against one wearying of it. Nor is there any lack of sport. Several fine trout waters are close at hand ; and the St. Hury's River, especially on the Canidian side among the islands affords as good fishing as mun ean desirc ; tnd game, lurge and small, is fairly plentiful in the woods.

An exciting anusement is running the wild rapids in a canoe mannel by Indians, it being an experience that the 
visitor will neither regret nor forget. At the foot of these flerce rapids is where the Indians spear the whitefish, and it is rare sport indeed for a novice to try his hand at this method of poor "Lo.' He may not make a success of it, but he will have much fun, and enjoy what we all want-novelty. The immense government works, the waterpower system and canals, and Fort Brady, an American military post constructed in 1823, and the immense pulp mills (on the Canadian side) are among the special attractions that never fail to int:rest all comers. And now a word to those who think the voice of the sirens of old is yet heard amid the murmur of waters, and that never a bird, nor the sweetest singer that ever faced the footlights, had a voice to thrill like the whirl of the reel. In the several channels and amid the shadowed waters, where the rocks overhang the depths surrounding Grand Manitoulin and sister islands, and in the north channel between those isles and the mainland, lurks many a huge black bass, fit for a master hand to play to his doom, and worth a king's ransom to land safely after the glorious tournament is fairly won. They are there, any number of them, grand, firm, game fellows, fierce and strong, in those ice-cold depths; and peradventure if you try their mettle, you will never regret the experiment. Of the shooting to be had in the forests of Michigan and that portion of the State of Wisconsin traversed by this route, little need be said. An experienced sportsman, speaking of the Michigan woods, says, "deer roamed, not singly, but in herds, and where a bag of ten to fifteen ruffed grouse was not considered anything extraordinary for a good cover shot." He had had but one season's trial of the broken prairie lands, rolling hills, and bushy ravines of Wisconsin, but deer were plentiful, bear ditto ; and stopping swift grouse and quail in the covers, and the long-winged "chickens" in the open, proved to be "for people who liked that sort of thing, just about the sort of thing they liked."

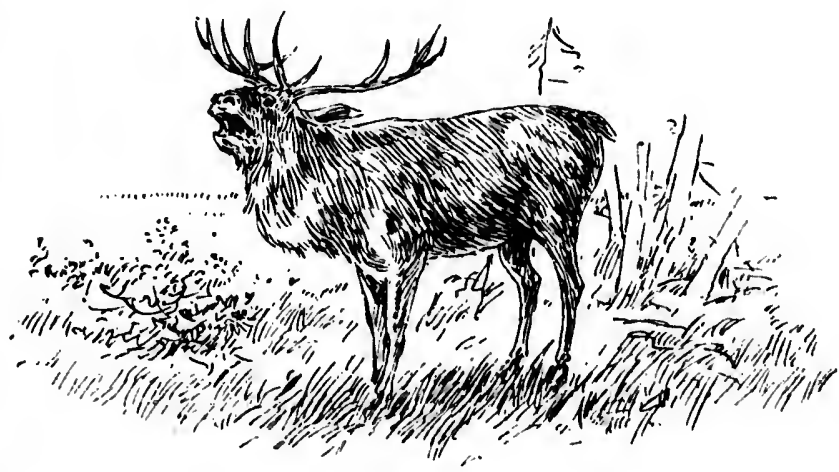




\section{THE CANADIAN NORTHWEST, THE ROCKY MOUNTAINS, AND BRITISH COLUMBIA.}

Amongst the finest shooting grounds to lie found in America at the present day are those inclosed within the boundaries of the Canadian Northwest. Few territories offer such a variety of game or equal the abundance of it, nor such splenclid facilities for leaching the haunts of the different species.

It is impossible to cover all the good shooting points in the vast expanse of prairies and brush-lands lying between the eastern boundary of the Province of Manitoba and the summit of the Rocky llountains, which mark the eastem contines of the Province of British Columbia. Roughly speaking, the prairie comitry is about 1000 miles wide, while other vast tracts extend far to the northward of the Canadian Pacific Railway, ofiering great inducements for special explorations by those who can derote sufficient time to the work. But the present intention is to treat merely of such points as can be reached readily from the railway, and direct the sportsman to places where he can enjoy his sport in comfort.

The pritiries and woodlands of Manitolog and Assiniboia are rich and extensive shooting grounds. Those who prefer feathers to hair can find shooting of a varied character, can count on well-filled bags, and what is perhaps, after all, its hest feature, from the nature of the country they can work their well-trained setter's or

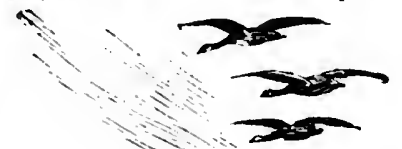
r a good broken sconsin, t grouse "ells" in sort of

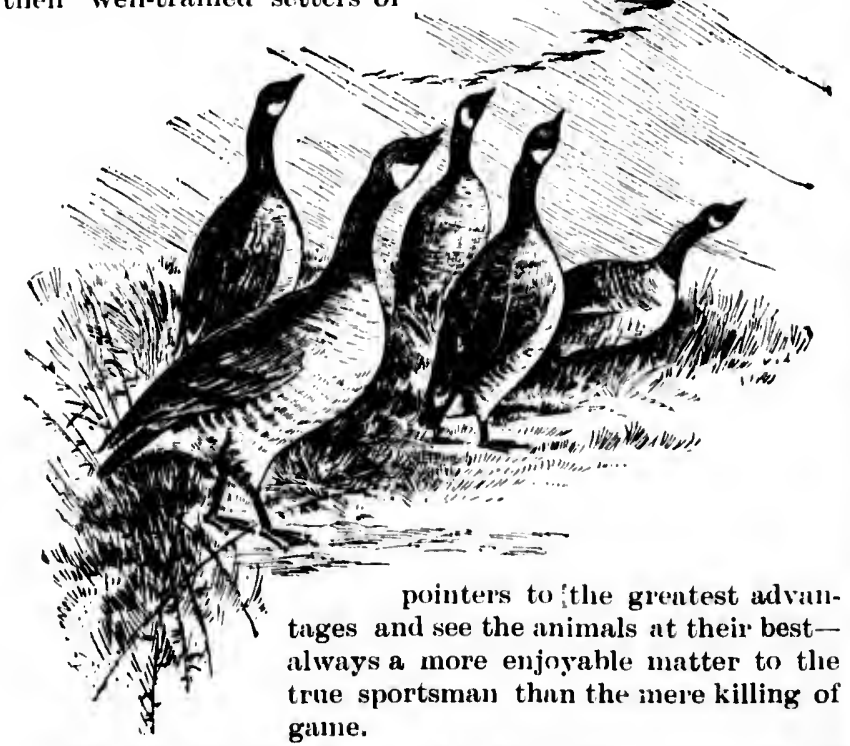

But the reader unacquainted with the country or the habits of Canadian game may ask: Wherein lies the special superiority of the Cantdian Northwest, and why is it better than any other region? 
The answer is easily found. In the first place, those rolling, grassy seas of rich prairie land, intersected with all endless succession of lakes and sloughs and swales, are now, as they have been for ages in the past, the spring and autumn haunts of the migratory water-fowl that every spring leave the drowned lands, lagoons, and rice-flelds of the south, and wing their long way over states and provinces, league after league, :until they have gained the lonely haunts in the north, where they breed. These lakes, streans, and marshes are favorite feeding places of wild fowl, and they brenk the vast expanses of grass everywhere. There is a practically inexhaustible supply of tood, and consequently the birds return year after year to the same points.

The prairies of the Western States, being very similar in many features, once swarmed with game, and portions of them are yet good; but the ravages of the horde of market hunter's were so terrible, that some of the best grounds over the bouder have been irretrievably mined. This is not the case $i-1$ the Canadian territory, nor is it likely ever to be. It is $y$, a new country ; and, though settlers are rapidly taking up the famous fat land, portions of it will always harbor wild fowl. Keen sportsinen were among the first to seek the new land when it was opened for settlement, well knowing what fields were there for the gun. They also knew of the tatal attacks upon the game in the States. Their turn came after; and, profiting by the result of the deadly work on the sister prairies, they determined to save their game from a like fate by properly protecting it. The value of their efforts is proved by the swarms of fowl now in the ancient haunts.

And there is big game also in plenty. The buffalo is practically extinct, 'tis true; lwit the giant moose, king of the deer' tribe, yet haunts many parts of the country where a proper amount of browse can be found. The elk, carihou, jumping or mule deer, common deer, pronghorn antelope, black and brown bear, gray wolf, lynx, coyote, fox, wolverine, beaver, and several other animals valued for their furs, are yet found in great numbers. But the great variety is among the feathered game. Several species of grouse may be killed, including the prairie chicken, pinnated grouse, ruffed grouse, spluce grouse, ptarmigan, and willow ptarmigan, in the northern part of Western Canada, and the blue grouse (cock of the mountains) in British Columbia.

Among the waterfowl are the trmpeter and whistling swans, the Canada goose, Ross' goose, lesser snow goose, and Hutchins' goose ; the Canala goose and the snow goose being the most nunerous. The mallard, black duck, canvas-back, redhead, pintail, garlwall, wood-duck, widgeon, green-winged, blue-winged, and cinnamon teal, spoon-bill, shoveller, golden eye, buffle-head, blue-bill, snipe, golden plover, and fifteen varieties of the same family, great flocks of curlew, and many waders of lesser importance are found. About every marshy bit the bittern and heron will be seen, and in addition to these, hundreds of cormorants, pelican, sand-hill cranes, coot, rail, etc.

And now to point ont a few of the many places where the game can be easily got at. In the wester'n portion of Northwestern Ontario, from Ignace to the Manitoba boundary, there are numerous lakes in which excellent trout and maskinonge 
can be obtained, while in the suall lakes, tuibutary to the Lake of the Woods and which are reached hy canoes from Rat Portage, black bass are fairly pientiful. In the extreme east of Manitoba, in the immediate vicinity of and between Renuie and Molson stations, is an excellent country for moose, perhaps one of the surest points easily reached from Winnipeg ; and here there should be no difficulty in securing specimens of this, the greatest of Canadian deer. Bear (black) are also very numerous ; there are plenty of ruffed and spruce grouse, and a few caribou. Sportsmen can travel comfortably ly rail to these grounds from Winnipeg in a few hours. From Winnipeg those looking for wing shooting may reach the haunts of prairie chicken and grouse (pinnated) by driving a few miles out upon the prairie, and in the brush in the valleys of the Red and Assinibone rivers ruffed grouse and Wilson and jack-snipe are plentiful, and sometimes mubits will he found; but ruffed grouse shooting is somewhat difficult, owing to the thickness of the cover. Snch a trip means starting early in the morning and returning to Winnipeg in the evening. Occasionally the fun is varied by knocking over a fev' duck and snipe at the sloughs.

Reaburn station, on the Canadiun Pacific, thirty-five miles west from Winnipeg, is a place well worth a trial. There are

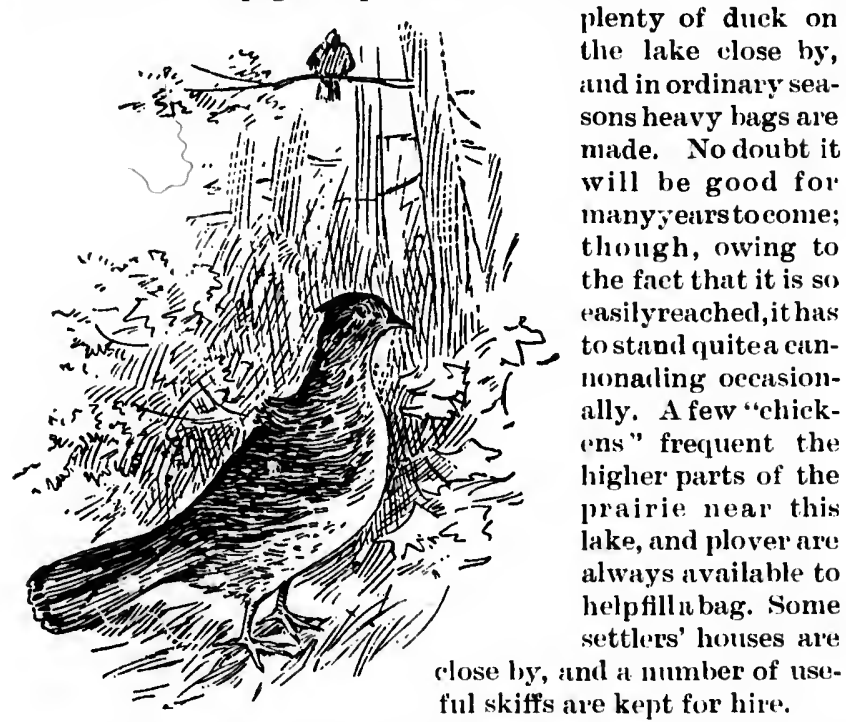

Should the sportsman desire a couple of days or more under canvas, he camnot do better than drive from Winnipeg forty miles northwest to Shoal lake. On the way across, prairie "chickens" will demand attention, and in the unsettled country on the north of the lake are a few moose and elk, and many black-tailed deer. The lake is a great resort for waterfowl of all kinds common to the province, and for mixed shooting it is A 1.

Another good point is Whitewater Lake, in Souther'n Manitob3, reached from Winnipeg by a short trip over the Pembina branch of the Canalian Pacific. Here "chickens," snipe, and plover are found in fair numbers, and there are 
thousands of geese, duck, crane, und other whterfowl. The eust end of the lake is reached from Boissevain, but at Whitewater stution, on the south shore of the lake, canoes and skiffs can be hired, and the fncilities there provided ennble the sportsinan to obtain good flight shooting when geese are going out to feed, and also to get into the favorite huunts of the canvas-back. Some great langs have been taken on the Whitewhtre-one of 516 ducks and 44 geese from four guns in a

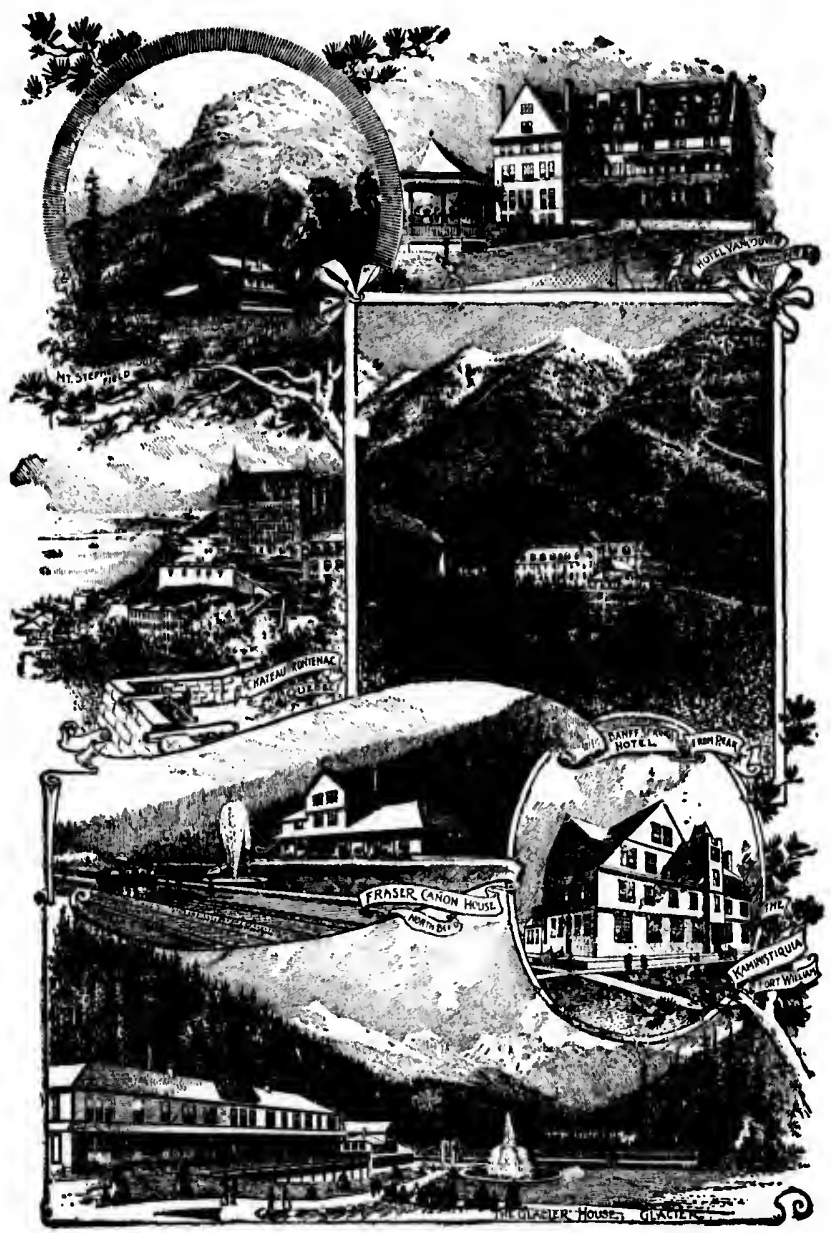

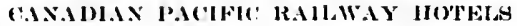

week leing recorded. Killarney Lake as well as Pelicin Lake, a little northeast thereof, are excellent spots, while on Rock Lake, near Clearwater, and Swan Lake, adjacent to Pilot Mound, good bags can always be had. North of Rock Lake are the Tiger Hills in the Pembina Mountains, haunted by elk, black-tailed deer, and black and brown bear; it also being a good locality $\mathrm{f}(\mathrm{r}$ grouse, as well as geese and ducks. Jackfish and mullet are plentiful in all the lakes, the former ranging from half-a-pound to 22 pounds. Camp outfit must 
l. The Whiteoes and able the re going 3 of the White. ns in

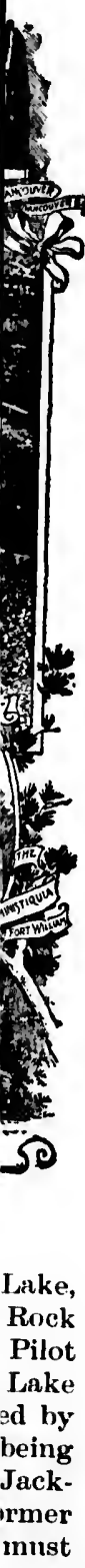

be taken, but the sport will well repay all trouble, as auple: occupation eun be found for both rifle and shotgun, chicken und ruffed grouse heing especially plentiful throughout the whole southwest of the province.

Lake Winnipeg offers still stronger inclucements. You go from Winnlpeg vin Canuliun Pacific Railway to Selkirk, and then drive or paddle down Real River, to the lake. The great marshes about the montly of Real River extend for miles, and form one of the lurgest duck giounds in the Northwest, and they actually swarm with ull kinds of wnterfowl in the senson. Hare the sportsumu cun shoot till his gun gats too hot to hold, anc: providing he holds struight, kill enorunous bags of choice luek. In the vicinity of Fort Alexander, nt the mouth of the Winnipeg River me moose, enribou and benr, and the Winnipeg and English Rivel's offer fascinating routes and grand scenery, should a further trip by enoe be decicled on. Upon the western shore of Lake Winnipeg, moose, cariton and bear will also be found, and about Big island and Grussy Nirrows uneounted flocks of geese resort.

lake Manitolya is also a - noted plice for waterfowl-

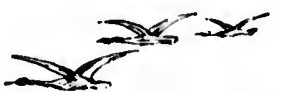

- which means that the bircls nre there in myrials. This latter lako is reached from Portuge la Pruirie, or by buggy from Wimipeg, stoping one night on the way at Shoal lake, alrendy nentioned : ancl in addition to the geese, duck, rte., the game list includes "chicken," and moose, elk and blacktailed deer in the Riding Mountuins. The town of Minnedosa is another promising centre for "ehicken," grouse and rabbit shooting, and from here the Riding Mountains may again be reached. There are also good spots near Strathelair and Solsgirth. The route to these places is via Yanitoba d Northwestern IRailway from Portage la Prairie.

'The Dauphin country is a veritable sportsman's paradise. Prairie chicken are always plentiful on the Dauphin plains, and big game, such as elk, moose, bear, and cleer abound in the forests of the Riding and Duck mountains, where the Dominion Government has wisely set apart a very large area, comprising several hundred thousand acres, as a permanent 'Timber Reserve, and which will become the "Adirondacks" of Manitoba. The waters and shores of Lake Dauphin and Winnipegosis afford a splendid summer resort or home and fecding ground for all kinds of waterfowl. Not only can duck be seen there in thousands, and also large flocks of geese, but the trumpet-like eall of that king of waterfowl, the white swan, can always be heard on these lakes, during the shooting season. The east side of Lake Winnipegosis is also a natural home for game of all kinds, where the moose, deer, 


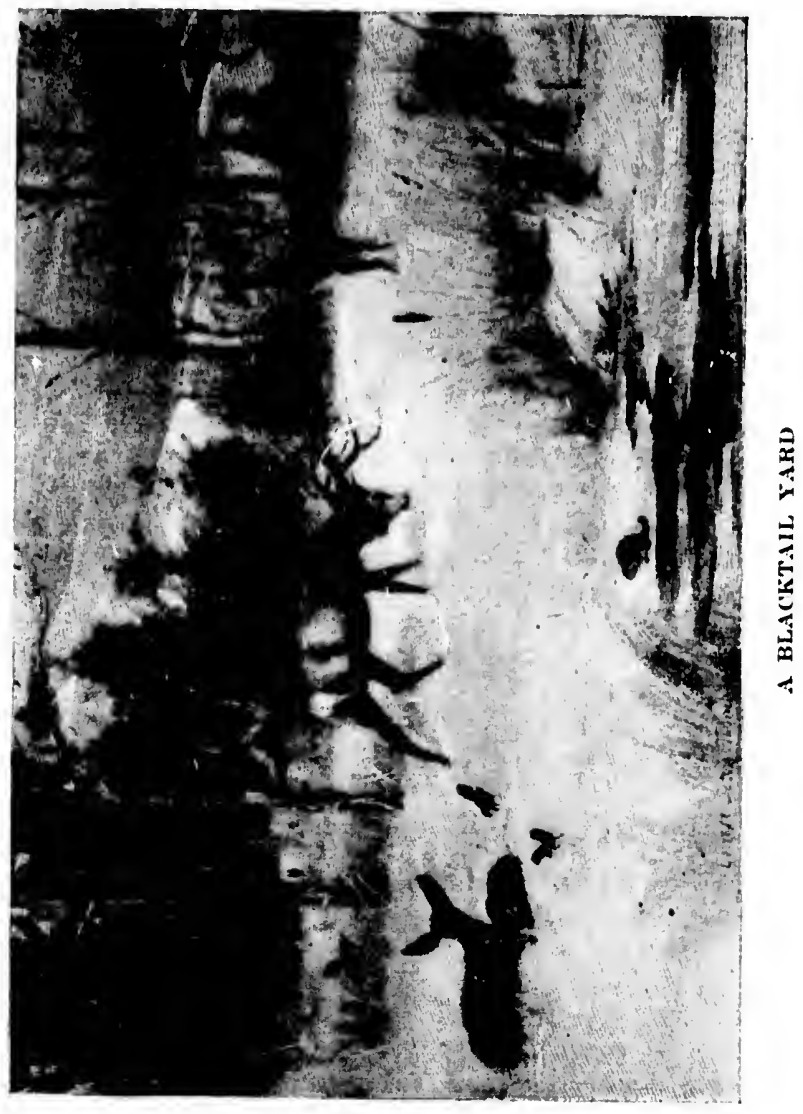


beri', and bauls of countless curibon romm in sylvan solltude undisturbed by the hunter. The Dauphin district is reacherl via the Lake Manitoba Railway \& Cunal Company's trains from Portage la Prairie to Lake Winnipegosis, and a branch runs to the northwest flom Sifton into the Swin River Val. ley where there is also good sport.

From MeGregor to Brandon, along the main iine of the C. P. R., the country is full of chickens, ducks und grouse. A drive across conntry from the former station to Holland, on the Southwestern branch line of the Camulian Pncific Railway, takes the sportsinnn through a perfoct paralise, as in addition to the winged gume there are rubbits, pririe wolves, jumping deer and bear.

Onk Lake is mother place where geese, duck and plover may be secured in numbers. The lake is within an ensy drive of the station, and a party tuking their tent, ete., enu make their camp, and have time to place themselves for the evening flight shooting. At the east side of the lake there is good camping groumd right in the line of flight, and on the north sirle the geese lenve the lake in lurge numbers to feed in thr. neighboring wheat-fields.

Between Oak Lake und Qu'Appelle whickens are plentiful, and durks are also to be had in the neighborhood of Brondview. North of Qu'Appelle big goume is also to be found.

At Yellow Grass, on the "Soo" branch line from Pasqun, gromd which has selilom been shot over, ducks, gene and plover are in myrials.

In the Dint Hills, abont 20 miles sonth of Regina, deor and antelope, besides wild fowl, are fairly plentiful, and in thr district about Reginn there are innmmelnble opportunitios for bigs of duck and chicken and nearly all the species of plover.

The "Mecca" of goose shooting is to be had on the soutl. side of Buffalo Lake, about twenty miles north of Moose Jaw ; wild geese in countless thousands come down trom their ferding grounds in the Arctic circle in the months of September and October, and remain there until they take their departure for the south when ice begins to form on the lake. The "ommtry to the sonth of the lake is well settled, and the wheatstubble field affords excellent feeding grounds. Proper hides lug in the stubble fields in the line of the flight of the geese and decoys set out will afford the finest goose shooting the keenest sportsman can imagine.

On the branch railway from Regina to Prince Albert, sportsmen can get good bags at Lumsden, and chickens and ducks at Duck Lake and Prince Albert, while in the illimitable pine forest beyond that town, which is reached by milway from Regina, game of nearly every description aloounds, Montreal and Red Deer lakes being especially good spots. Complete outfits can be procured at Prince Albert.

Rush Lake, a few miles from the station on the main line of the Canadian Pacific Railway, is one of the finest points for geese, duck and other waterfowl, where large bags can smrely be made.

Farther west, again, is the antelope country : Swift Current, Maple Creek and Medicine Hat being among the best outfitting points for a trip after these, the most beantiful animals of the plains. At Calgary, in sight of the "Rocl-ies" 
superb sport can be enfoyed with the grouse among the brushy foothills of the giant range. Cood shooting may be found within easy driving distance of the town, and glorious mountain-trout fishing on the Bow River and its tributaries, to say nothing of the delights of visiting the ranches and being entertained bv those princes of good fellows, the ranchmen. North of Oalgary is the Red Deer region, ensily reached by rail, a grent one for big gume, between the railway and the mountains, and further north still, beyond Elmonton, in the Great Mackenzie busin, a field is offered the more alventurous hunter. Buffalo range in small bauls west of Great Slave River, but there are only a eomparatively few left of these noble monarchs which once dominated the plains, and iney are protected. The country is sparsely inhabited, and there are excellent opportunities around Lake Athabasca and Great Slave Lake for securing elk, moose, bear und jumping deer, and in the "hurren lands," north-east of Great Slave Lake, are musk-ox and reindeer, the Jatter being sometimes found as far south as Lake Athabusen, and at neurly all points en route are ducks, swun and geese galore. There are white fish and trout in the lakes and rivers. The trip commences with a $80-m i l e$ waggon-ride to Atluabusca Landing, from which stenuers belonging to the Hudson's Bay Co. run to within the limits of the Aretic cirele. Inquiries at the Compuny's offlces at Winnipeg should be made, however, before the trip is undertaken, to prevent disappointment, as the stenmers run at infrequent intervals.

In Southern Alberta, renched by the Iacleorl branch from Calgary, or by the Crow's Nest Pass Ry. from near Medicine Hat, in that portion of it lying between Macleod and the mountains, there is the same variety of game to be found as in other parts of the Northwest Territories, with the adlition of blne grouse (cock of the mountains), as the foothills are approached. There is good chicken, goose, swan and duck-shooting between

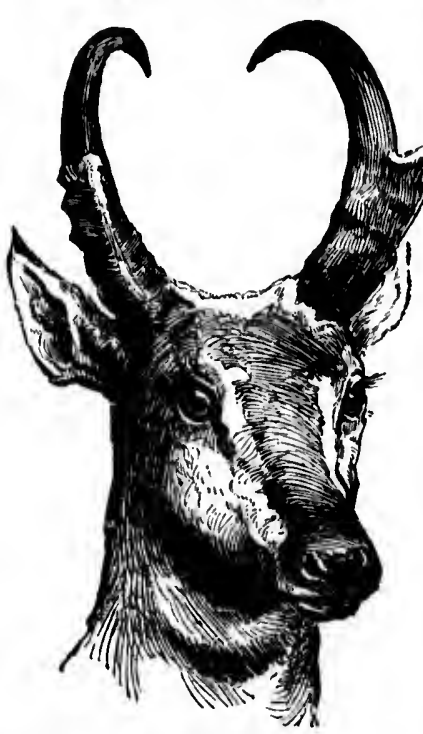
Macleod and the international boundary. Trout are plentiful in the three brunches of the Old Man River and in its numerous tributaries west of Macleod, and the most enticing bait for the big ones is a mouse. There is also good trout fishing in the St. Mary's and Waterton (also called the Kootenay) and in all their branches, and capital sport with either gun or line can be obtained in the chain of Kootenay Lakes on the eastern slope of the Rocky Mountains. Salmon trout weighing from fifteen to forty pounds are among the catches in Eastern Kootenay. In the mountains back of these lakes, grizzly, cinnamon, silver top, brown and black bear, mountain sheep and goat are fairly plentiful. Guides are necessary and 
the tourist can be directed to them from any of the settlements and stations along the ine of the Crow's Nest l'ass railway, which has brought the great undisturbel game country within easy reach of the sportsminn.

So much for the sport of the priniries. We have now skimmed over the great grassy sen, tonching briefiy on the most prominent of the many localities to choose from, the intention being merely to give the strunger a few hints of the wonderful resources of the country from $n$ sporting point of view.

Lying in the little tent beside the chosen water, on the flist night of his jaunt, the sportsman whiffs the last pipe, and his gaze tries in vain to pierce the guthering mists and shadows creeping over the "level waste and rounding gray" of apparently illimitable priaice. Before him stand the tall buttalions of rushes marking the boggy shores of the lake, dark and mysterious, like a shatlowy wall. The nir is filled with the push of swift wings, as the restless fowl seury hither and thither ere settling down. A strange but, to him, wondrous sweet meledy of cries comes with the lazy breeze. The honk of goose, the quack of mallurd and the chatter and gabble of unseen hosts, are the lint sounds his ear's detect as he drifts into the shallowland, with a golden promise of glorious sport with the dawn. The promise will be well fultilled, for those same weird cries and the hum of wings will begin ere the early breaking of the northern day : and when night again falls there will be no appaterent diminution of the winged army, but he will have a well-filled bag, such as call only be made in this, the sportsman's El Dorido.

It should not be forgotten that many af the lakes and sireams of the prniries are stocked with fine fish, including maskinonge, pike, pickerel, etr.., and they furnish a pleasant chunge of occupation during weather too warm for ganu to keep, or when it is desirable to give gtm and rifle a rest.

Camping ontfits, conveyanees, helpers and everything

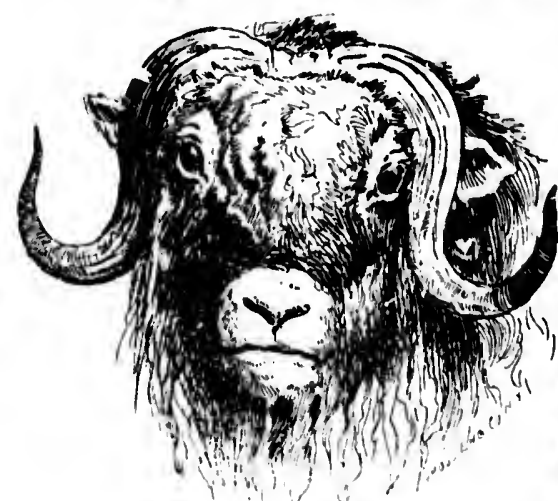
necessary for a hunting exemrsion upon the plains (an) be readily serenered it Winnipeg, and the sportsmin need not burden hinself with anything beyond his personal affeets. He (an) enjoy an unsiurpassed train serviec so long as he follows: the latway, and should ho diverge from the line, there are no hardships to

be undergone beyond what are suffleient to give a spice of adventure to the experience of a holiday in the wilds.

Next to be considered are the "Rockies" along the main line of the Canndian Pacific, the first of the flve ranges lying between the grent pritice belt and the Parific Oceun. Over ¿00 miles of the grandest scenery must be passed ere the western sen is renchel, und nearly all of this chnos of momntuins 
tlements railway, country

we now $y$ on the om, the hints of ug point

the first and his hadows f apparttalions ark nud vith the her and ondrous he honk abble of le drifts us sport ir those he carly in falls uy, but in this,

:es and cluding leasant inme to

ything humt11pon an be ed nt (1) the di not I' with nd his \&. He 1111: ervice bllows a II I iverge? ther' jus to ice of

main lying Over. westitnins
Ins wild as it was when first the ayes of the white man were startled by their overpowering grandem, Upon or anong these murvels of old-time rock-luilding are the finvorite hants of every "man-fearing or man-skeering" brute known in the whole country-clk, moose, deor, caribou, Rocky Momntain sheep and gont, panther, grizzly, black and hrown henr, lyox, wolf, etc, etc., while waterfowl abomed "1pon many of the mountain lakes, and several varieties of grouse are in the forests. But you would uever rome nwily over here for feathered gane, whon it may be so cisily got upour the plitios.

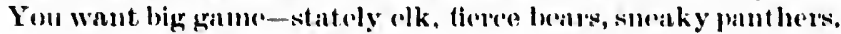
hig-horned sheep, stowy goats, etce? Very good, rou can have them, one and all, and callow and dean to boos, provide ing your yoursolf are gimme to follow your guide.

Now, there ane places without mumler almong these monntain ranges where a man can find many of the varieties of the gitme mentioned; but mention need only he makle of a few, foom which a sportsuan may safoly plan his operotious.

The flist important halting place is at Banlf, in the C'moalian National lark, Rocky Momutains, whe're the milway company has cerected a palatial hotel. Should a brief sojourn hore be decidad upon, the sportsmun may enjoy good duckshooting on the Vormilion Lakes. a short distance from the hotel, and tine momintain trout flshing on the Bow and Caseade rivers: also doep trolling for lake tront on Devil's Lake, all but the litter within rasy walking distance. (inides and complete outfits can be secomed for extended trips into the momitains after bear, sheep and goilt, to the north, somth, or wost.

Farther westwarl, at Field, is one of the Compmys inviting little châlet hotels, and there and at Bunerald lakke seven miles away good tly flshing can be had: but it is hardly a desirnble point for showting. Still finther west is the town of Golelen, and from here n stramer makes regular trips up the Columbia Rivel to the lakes at its head. distant, abont 100 miles, and atrording alecess to a fine game district in wuch are sheep, front, raribou amel heilr. Outllts ran be procured at (iolderi, and guides and supplies at Windermere, 'ilhe lagoons on cach side of the steamhoit chumuel swatm with duck, geese and swin-in filct, they ane the farorite breceling gromuls of the water-birds, and the hodwaters of the piver atford excollont trout and grayling flshing. West ward, ngain, the next important stopping-place is at the foot of the creat cilacier of "he Selkirks, where the railway eompmy have another of their comfortable momintain elohlets, which, with its anmex,

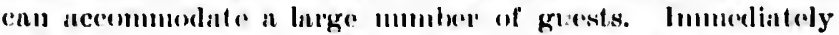

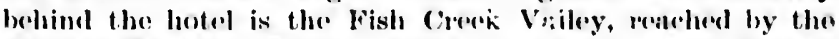
Asulkan Pass and Glayjet, Asulkan memning in the Siwash

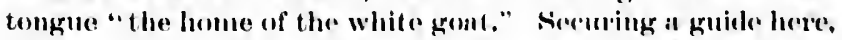
you cun climb the mountains with a certainty of a chunce at

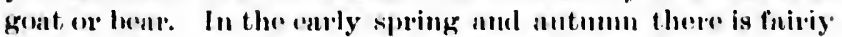
good fly flshing in the streans uene the Glneier Hotel.

A new water, and ome that has alrouly become fameus, is the Lower Kootenay River, which torms with mountain trout of fair size. The many who have tried it agree thut it is one of the hest stroums available, while the scenery is simply superb. The country contiguns to it is well stocked with hig gome. 


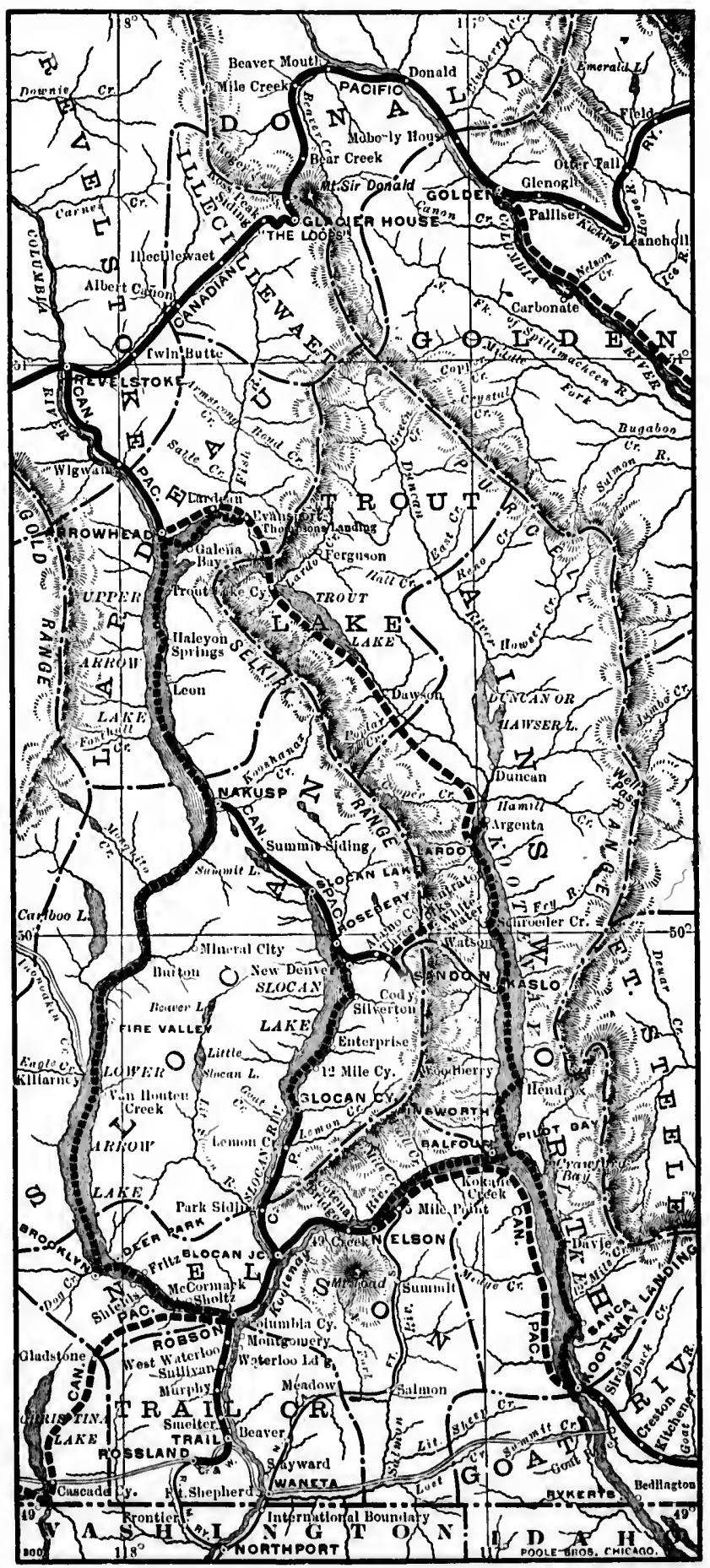

MAP OF THE KOOTENAY DISTRICT, HLITISH COLUMIBA. 
having only lately been rendered accessible. The headwaters of the Kootenay Lakes and River rise a little west of Banff, and flowing south into Montana and Idaho return to British Columbia and empty into Kootenay Lake, again discharging its waters into the Colnmbia River near Robson. The river is, in great part, below Nelson, a succession of cascades, beautiful from a scenic point of view and abounding in rainbow trout, from one pound upwards, that are greedy for the fly. It is an ideal stream, rushing through gorges, and over rapids broadening into pools and forming numerous "just the spots" into which, practically, any length of line can be cast withont the least obstruction from bushes or overhanging trees. And it possesses the inestimable advantage of being entirely free from mosquitoes and black flies. The Lower Kootenay is reached by two routes : Either by the Crow's Nest Pass Railway which branches off from the main line of the Canadian Pacific near Medicine Hat in Alberta, or from Revelstoke station, on the main line, and thence by branch to Arrowhead station, on Upper Arrow Lake, and thence by the fine new steamers, Rossland and Kootena!y, of the Canadian Pacifie Ruilway Company, through the Arrow Lakes to Robson,

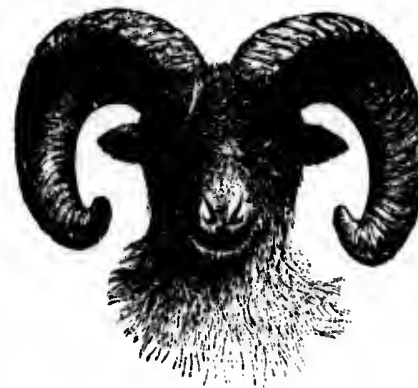
and thence by rail, or by rail from Nakusp on Upper Arrow Lake to Rosebery, on Slocan Lake, and down the lake by C.P.R. steamer to Slocin City, thence by rail to the Lower Kootenay. A month's onting in this region would be the beare ideal of a sportsman's holidity. The hest fishing is just below the Lower Falls, 13 miles from Nelson. Tourists can go out from Nelson in the morning and return at night. At Nelson (where fishing is also good) camp outfit, consisting of blankets, tents, cooking outfit, such as pots, pans, plates, cups, knives and forks, etc., can be hired for a small charge. Supplies and all sorts of provisions of the best qualty may be purchased at reasonable prices. Good rooks can also be engaged at Nelson to accompany fishing parties. Tha' necessary camp outfits will be carried free between Nelson and the different fishing camps, and the trains each way between Robson and Nelson will stop (when flagged) to take and put off the fishing parties. In short, everything has been arranged with the view of affording every comfort and facility to those who may wish to spend it few days in the Kootenay district enjoying the fishing, which is not surpassed anywhere on the continent. As very few fish are caught under a pound weight, and rumning up as high as three and four pounds, anglers should provide themselves with a gaff or landing net, and be particulir to see that their flies and tackle are good and strong.

No guides are required on tho Slocan River, which empties its waters into the lower Kootenay. There is good fly-fishing in this stream.

In the Slocan district of the Kootenay, which has just been opened up by the building of the railway from Nakusp to Sandon, there is good brook trout fishing in the streams 
that empty into Slocan Lake, while the lake itself offers excellent deepwater fishing, of which the gold prospectors now in that neighborhood are taking advantage.

Good hotel accommodation will be found at Revelstoke, Arrowhead, Nakusp, New Denver, Slocan City, Slocan Junction, Nelson and Rolson; and any further information will be cheerfully furnished on application to the Company's agents at those places.

From south of Revelstoke to Robson, on both sides of the river and lakes, goat and silvertips can be got within a day's tramp from point of landing. Deer are plentiful between Nakusp and the international boundary.

The Lardean district, reached from Arrowhead by steam launch, also offers a good field for the sportsman.

Asheroft and Sarona's Ferry on the Thompson River ure good waters, where not only large catches are made, but where the bulk of the catch are big fish, the silver trout running from one to four pounds each, and hard fighters. In the Kootenay Lake, and also in Kamloops Lake, land-locked salmon are taken. Proffessor Jortan, who caught them in hoth waters, speaks of them as ouananiche, and has dubbed them Oncoihyuchus Kamloops.

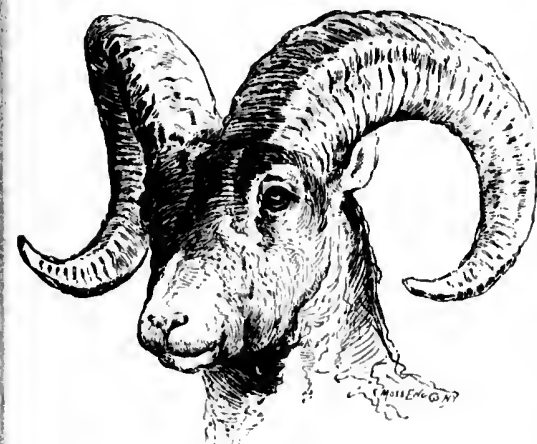

In the Okanagan Valley (reached by rail from Sicamous, on the main line, to Okanagan Landing and thence ly steamer) there is in abundance and variety of large and small game, this being par earellence the great game region of America. Deer appear in vast herds,and at clifferent points mountain goat, bighorn, black and cinnamon bears, moose and caribou are plentiful, and there is an oecasional grizzly.

There is more excitement in tackling the congar and wildcat, and there are even wild horses in the foothills, if one is not particular as to his quarry. There are numerous ranches in the valleys paralleling the lake, and several landing places from which the hunting grounds, which are not surpussed in the world, can he easily reached. There is also good trout fishing in the waters of Okanagan Lake. Efficient guides and hunters, all necessary horses and complete camping outfit can be obtained at Vernon, Kelowna or Penticton, at the foot of Okanagan Lake. This was the scene of the famed lunting trip in British Columbin of Archduke Ferdinand of Austria on his tour around the world.

Further sonth, between Penticton and Fairview, vust herds of deer are frequently seen.

There is good fishing, also, at several points nearer the coust. Tourists stopping at Vancouver can get a good day's fly fishing at Coguitlam River, seventeen miles by train to Westminster Junction, where there is a good hotel. 
offers pector's

lstoke, Slocan mation pany's

sides of within lentiful

steam

ver are le, but int runIn the l-locked hens in dubbed

Valley 11 Sicaline, to g and there is wiety of ne, this lce the Aneriin vast $t$ points ighorn, n loears, re plenil ocea-

ha wild$f$ olle is ranches r. paces issed in d trout des and tfit can foot of nunting stria on

v, vast

rer the d day's rain to

Capilano Creek or Seymour Creek, alout an hour's row across the bay from Vancouver, offers a good day's sport, while at the mouth of either stream during low tide sea trout weighing from two to seven pounds ufford excellent sport. In the months of August, September and October, a good day's sport may be had tre!iing for salmon in the bay. Pacific Coast sulmon will not rise to a fly, but as many as fifteen or twenty fish, varying from five to twenty pounds, are sometimes killed in an afternoon with the rod after being hooked with the troll hook.

Harrison Hot Springs, reached from Agassiz station on the Canadian Pacific Rnilway, is a pleasant summer rosort about forty miles frc.n Vancouver, from which the angler ca's reach excellent waters. An hour's row across Hurrison Lake will take hin to streams where more trout can be killod in a day with fly than he would like to carry far.

Excellent trout fishing is to be had at Lake Beantiful on Burrard Inlet, twenty-three miles from Vanconver, which is reached by steam launch to be procured at any time from boatinen.

At many points on the coast one can obtain sport with deer, bear, grouse, and waterfowl. And again another field is open on Vancouver Island, that land beloved of Englishmen, There is excellent fishing in Gowithan, Duncan's and Shawnigan Lakes and in numerous rivers and streams. Within short distances of the beantiful city of Victoria, grouse and the blus quail, generally styled California quail, are plentiful, anı favorite game with the residents and visitors. A short journey into the interior of the island will bring you to the ringes of deer and bear', both being readily killed, and elk is to be foumd in some places, the island being the only part of British Columbia in which it ro:ans. Added to these are seve: ' varieties of duck, etc., and last of all the English pheasant, introduced several year's ago, and now perfectly arclimated and thriving wonderfully in the new land. The cry of "mark cock," or "ware hen," may sound stringe to many; but the newly arrived Briton knows right well what it means, and what rare sport the long tails furnish : and it is ten to one that he kuows how to stop them, too. These birds are also found in numbers on Lulu Island and Sen Island, at the month of the Fuser, within five miles of New Westminster and fourteen of Vancouver (by excellent roads), where duck, snipo, and plover, too, are in great abundance in season. Information about these places is to be galned at the Canadian Pacific Railway Company's offices at Vancouver and Victoria.

And now, in eonclusion, $a$ few words ahout the country just covered.

The pursuit of what is generally dubber. by the craft " big game" in the mountuin wilds of Canada is no child's play. To be successful, a man must possess iron nerve and unflinehing determination; he must be a good shot, und strong enough to stand rough work; for the latter is frefuently necessary before the game can bo reached, and the former is very liable to be an extrenely aseful accomplishment, especially if the quarry huppens to be a grizzly bear.

The nccounts pmblished by parties and by individual sportsuen of their shooting trips through the Northwest und 
British Columbia are legion. The general tenor of their letters may be found in an extract from a letter written by the Bloomington Hunting Club, which went through the country recently in a private car, stopping over at those points pre-arrunged for exploitution. They say : The sport met with on the line of the Canadian Pacific Railway more than fulfilled our expectations, and many of the party will return home with hondsome souvenir's in the shape of goat, sheep, caribou, and deer heads, and pelts of the grandest big game of this continent.

Sportsmen who have shot in the famous wilds of Africa and India are apt to fef 1 proud of their lion, tiger, and other handsome skins that originally covered the works of some lithe and bloodthirsty big feline; but, with all dne respect to them and their prow. ess afield, many would prefer the hide of a grizzly of their own killing than half a dozen peltries of "Leo" or "Stripes" or any other cat that ever jumpec. Although undoubtedly there have been many oec tsions when itwas a nice duestion whether at the close of the affair the

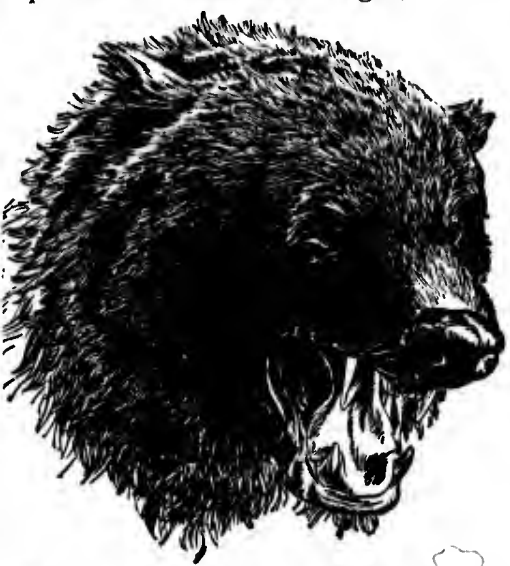
tiger would be carried into camp or would find inside accommodation for the hunter, and althongh we know that men hunting in South Africa have occasionally feit that a lion looks best behind the bars of a menagerie, yet, as a rule, you can "pot" your lion over a earcass, and be yourself, meantime, perfectly safe on some prepared post, or natural stronghold; you can bore holes between the stripes of the fur "blazer," worn by his feline majesty of Bengal, while you yourself are squatted in a howdah, strapped to the lack of a twenty-odd hand elephant, while a tribe of bare-legged natives yell and scream ant hoot to keep their own courage up and drive the jungle prowler to the "Sahib." You will probably get the tiger, and, should he charge, experience a temporary excitement, but not often incur much danger.

Shooting the grizzly is other work. The big plantigrade is always looking for trouble, and when he digs up the hatchet he goes on the war-path. You will have no friendly elephant, nor army of beaters, to satisfy his craving for somebody's scalp. You start on his track and follow him into his gloomy fastness amid a chaos of rocks, with your life in one hand and your rifle in the other'; and, unless you are made of the right material, stop before the scent gets too hot, or peradventure you may be found empty hunded by your party.

However, this spice of dan-, or rather this danger spiced with a chance of escape, is very fascinating; and, if you would fain be fascinated to your heart's content, seek the Rocky Mountains of British Columbia and enjoy your whim.

And such fields for sport. Not pen, nor brush, nor tongue can convey the proper idea of the sublimity of those niarvellous 
mountains; they are something too imposing for mere words ; they must be seen and stulled. One must live among them and watch the glories of sunlight upon their everlasting snows and glaciers; one must elimb their steeps and breathe the eold, thin atmosphere of those dizzy elevations, and truin his eyes to mensure sonring pinnacles and dark alysses ere he can realize their stupendous grandeur. One must hear the thundrous voice of the whirlung storms amid their peaks; the avalanche tearing the forests from their native slopes; the avulsion of crag and native houlder from huttresses frowning darkly above the clonds, and the booming echoes of waves of mighty sound breaking against the walls of unmeasured ravines, ere the full power of those matchless monuments of the old-time war of forces is impressed upon the mind. And then the glory of laying low the game that haunts them. Right well did the Indian hmuter know what tested manhood, when first he wrenched the great seimitar-shaped laws from the broad fore-paw of the dead grizzly, and string them around his neck as a token to prove a nan. Time has changed many things, the rifle has supplanted the bow, but nothing has supplanted the grizaly ; he is there yet, the king of the wilds ; his claws are yet the proulest ornament the savage cau wear, and his skin the most valuable trophy of the white sportsman. Up above the grizzly's range are found the white goats and the fumous big-hol'n mountain sheep, both engerly sought after by sportsmen; the latter especially for their liandsome heads.

Excepi from bears the sportsman runs little chance of getting into difficulty. True, it is clained by some that the panther is an ugly customer, writers even going so far as to say that he is more dangerous than the grizaly, and sometimes proves his superiority in a dispute over a earcase. Such statements are believed to be mere rubbish ; for the panther, lithe and powerful though he may be, is a great, long-tailed, bewhiskered coward; a bravo of most terrifying aplwarance, but mighty careful of his handsome skin ; in fact, what he is generally termed by the herder's and hunters-a big snoak cat.

The latudsomest game of the Rockies, is, of conrse, the noble elk, or wapiti. Their immense branching antlers, and the elean-cut, blood-like appearance of their heads, make them particularly attractive ornaments for a gentleman sportsman's home, and they are in great lentand. The species is now rare in many localities where they formerly aloounded, but they are still plentiful among the foothills of the Roekies, and they can also be found on Vaneouver Island, in the Northwest Territories, and in Manitobn north of Selkirk, and sometimes in the Duck and Rirling Momtains.

Next to the elk ranks the caribon, and a royal quarry he is. They are very plentiful abont Eagle Pass in the Selkirk Range, near the Shuswap Lakes, and in the Okanagan district, and there should be no difficulty in securing fine specimens. They are also found in Manitoba, in the region between Lakes Wimnipeg and Manitoba, etc., and wonderful storiess are told of great herds in the Peace River conntry.

The several species comprising the gane list montioned alove are distributed thronghout the mountains in greater. or less numbers, being plentiful wherever the conditions ar. 
favorable. More minute details eoncerning them ure impossible in a book of this nature, and unnecessury, as the game, except at n point here and there, is as abundunt as it wis before the first rifle shot woke the echoes of those monstrous canons.

The sportsman contemplating a trip by the Canadian Paciflc Railway across the continent to these fields of sport must beur in nind that heavy wenpons ure needed for sitisfactory work. Lighter ones may do-the Indians kill grizzlies with the lightest Winchenter rifles; but it is better to tnke a repenter of the heiviest make. Plenty of powder and lead means sure work if the rifle is held right, and by using such you will lose less wounded game, and grently lessen the risk of a clawing from some infuriated beir. The Indians, it must be remembered, are grently your superiors, both in the approach of, or retreat from dangerous game; they steal noiselessly and patiently upon their victim, and never fire until they are at close range, and sure of dropping it in its tracks. You will not be able to accomplish this, and therefore require a wenpon that will do deadly execution at nny reasonab'e distance. Properly equipped, you will drop your bear or elk cleanly and well; and when your holiday is done, and you are speeding homeward by the "Royal Road," with your muscles strong after glorious work, and your skin tanned by the mountain air, you will think over every moment of your outing; of the splendor of the sunrise, the magniflcence of the scenery; the glaciers, the torrents, and the thuusand and one marvels of the wonderland you have left; your beautiful trophies, and, as you take your last backward glance, ard your straining eyes catch the last glint of the snow-clad peaks, you will say "My heart's in the mountuins," unless, 'indeed, it should happen to have been left elsewhere.

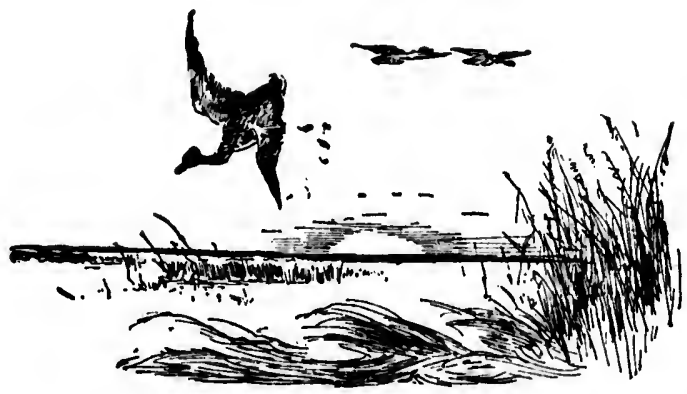




\title{
Export of Deer, Caribou and Moose
}

\section{CANADIAN CUSTOMS REGULATIONS.}

\author{
MEMORANIUU
}

No. 106i3 B

CUSTOMS INISAITMEXT,

\section{To Collector of Customs:}

Ottawa, 18th August, 1899.

The following Regulations respecting the Export of Deer, shot for sport by persons not domiciled in Canada, have been marie and estalblished, viz.:--

1. Deer when shot for sport under Provincial or Territorial Authority in Cunada, by any person not domiciad in Camada, may be exported under the following eonditions and limitations :-

1. 'The deer may be exported only at the Customs Ports of Halifax, Farmouth, McAlam Junction, Quelsec, Montrenl, Ottawa, Kingston, Niagara Fulls, Fort Frie, Windsor, Sault Ste. Marie, Port Arthur, and such other Ports as shall from time to time by the Minister of Customs he designated for the export of deer.

2. The exportation of deer in the carcase or parts thereof (exeept as to cured deer heads and hides of deer) slatl be permittel only during or within fliteen days after the "open seuson " alluwed for shooting derr under the laws of the Provinee or Territory where the deer to be exported has been sho

3. No person shall in one yenr export more than the whole or parts of two deer, nor shall exportation of such deer be mide by the same person on move than two occisions during one calendar year.

4. Deer in the carcase or any pa: thereof which has heen killed in contravention of any Provincial or 'Territorial law shall not be exported, nor shinll any deer in the carcase or parts thereof be exported without the permit of the Collector of Customs aceompinying the shipment.

5. A person, not domiciled in Canada, who has shot deer for sport and not for gain or hire, under Provincial or Territorin Anthority may make an export entry in duplicate of deer in the carcase or parts thereof so shot hy him ind allowed to be exported-upon subseribing and nttesting before a Collector of Customs a Declaration in the following for'm to be anne ed to sitid export entry, viz.:-

\section{(A \& PER Form in Aplendix)}

6. The exporter shall produce his lieense or permit for shooting deer under Provincial or 'Territorial Authority to the Colleetor of Customs before the exportation of the deer, and the Colleetor shall endorse thereon al deseription of the quantity and purts entered for exportation.

The Collector of Customs at any Customs Port of Entry designated for the Export of Deer, upon receiving the suid export entries duly completed, may thereupon under the seal of the Custom House, issue his permit for the exportation of the deer, if satisfied as to the identity of the sportsman and that the exportation is not prohilited.

\section{JoHs McDougaLD,} Commissioner of Customs. 


\section{A PIENDIX.}

Form of Declaration to be mate in connection with the Export of Deer, shot for sport by persons not domiciled in Canada.

I. . . . . . . . . . . . . . . . . . . . . . . . . . . . do soleminly und truly dechire that the deer in the carcense or parts thereof deserilied in the annexed Export lintry have been shot by me at...................... in Cunada, for sport and not for gain or hire, under Anthority of the License or Permit issued under Provinclal or 'Territorial Authority herewith exhibited; that I am not domiciled in Cnnadn; that I hinve not exported directly or indirectly within this calendar yenr deer in the carcase or parts thereof, shot by me in Cnnadu during the present senson, except as follows, viz.:-

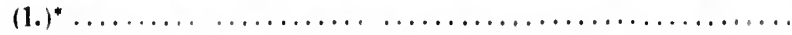

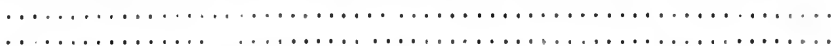

that the dece described in the minexed Export bintry together with the cleer heretofore exported hy me within the present calendar yeur are not purts of more than two deer; nnd I verily believe that the exportation of the deer deseribed in the annexed entry is not prohibited.

Declared before me $\| t \ldots \ldots \ldots \ldots \ldots \ldots$

Siguuture of Eiporter.

this........diny of .............

\section{Collector of Customs.}

(1*) Parts exported and p'ace of exportation.

As export from Canada is permitted only at the ports specified, sportsmen should ship from the interior to the most couvenient authorized Customs Port shown in parngraph 1.

Certificates of membership of hunting or fishing chubs are not valid licenses or permits under elause 6. The reguln Provincial License for the current lunting season issued by at person anthorized by the Commissioner of Lauds, Forests and Fisheries must be produced.

On sufficient notice to General Passenger Agent, C.P. Ry., Montrenl, direct, or through any C. P. Ry. agent, a passenger representative will meet any party of sportsmen, and assist them in making necessary Customs arrangements.

\section{Tourists and Sportsmen's Outfits}

\section{CANADIAN CUSTOMS REGULATIONS}

The articles which may be brought into Canada (in addition to wearing apparel, on which no duty is levied), as tourists' outfits, comprise guns, fishing rods, canoes, tents, camp equipment, cooking utensils, musical instruments, Kodaks, et.e, ete.

A deposit of duty on the appraised value of the articles imported must be made with the nearest (Collector on irrival in Cinuda, which deposit will be returned in full, provided the articles ure exported from Canada within six months.

Toul

of . .

from

he cil

'Tomri

saicl I

(intry

depos

(:0111)

ment

Decela

this and e 


\section{REPORT FOR DEPOSIT ON TOURIST'S OUTHIT}

(In Inuliente)

Hutry No.

Report No.

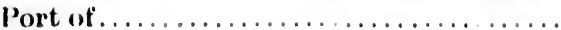

...................... 100.

Toun:ist's Ontflt imported hy......................

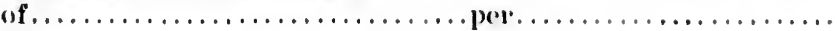

from

\begin{tabular}{|c|c|c|c|c|c|}
\hline $\begin{array}{l}\text { Marks } \\
\text { and Nos. }\end{array}$ & $\begin{array}{c}\text { Descriptions of } \\
\text { Articles. }\end{array}$ & Value. & Rate. & Duty. & $\begin{array}{l}\text { Remarks re } \\
\text { lixportation. }\end{array}$ \\
\hline & & & & & \\
\hline & & & & & \\
\hline
\end{tabular}

The sail deposit of . .......................... thollars has boner received by me on the conditions stnted hy tho im)porter.

[ST:IM11]

Customs Officer.

1. (owner w' ngent) ilo soleming decinie that the above is a fuil and true statement of the clescription and values of the articles imported by me as 'Tomrist's Ontfit, with the amount of duty deposital thereon, the said cleposit to he ontered for duty if the articles are not duly exported within six months.

(Sigmature)

(Acldress)

If the tourist is unable to have his outfit exportod and identified it the Customs Port where the doposit of duty is made, so as to receive back his deposit before leaving Canada, he can have the articles inspected and certified as helow. The 'Tourist's Report of the articles exported and certified as afore. saicl may then be mailed to the Customs Offleer at the port of (ntry, who will forward a remittance, by mail, for the money deposited (less expense of remittance).

'The articles which may he brought in as 'Tonrists' Outfits comprise: Guns, Fishing Rods, Canos, Tents, Cump, Bquipment, Cooking Utensils, Musical Instruments, Korlaks, etc.

Dectaration as to returu of Outfit, attested to before a Customs Officer in Canadie or "at " place out of Cunada.

Articles deseribed herein inspected by me at........... this................. day of ..................... incl exported or. landed as declared.

sworn to before me,

[S'TAMP].

Customs Officer.

$\mathrm{I}, \ldots$

(owner or agent) do solemuly declare that the identical goods hereinbefore described are now presented for inspection, the same having heen delivered for exportation from the port of . . . . . . . . per.................... or landed $n t \ldots \ldots \ldots \ldots \ldots \ldots \ldots$

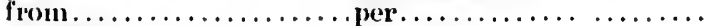

(Signatme)

(in ad-

is tours, camp odaks

cles imcival in led the

No. 1006 B.

File 37827.

On suffleient notice to General Passenger Agent, C. P. Ry.. Montreal, direct, or through any C. P. Ry. Agent, a passenger representative will unet uny party of sportsimeu and assist them in making necessary Customs arrangements, ete. 


\section{Protection of Forests from Fire}

The value of the l'mulian forests ean hardly be overe

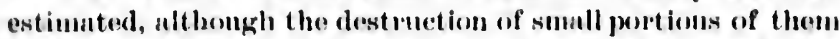

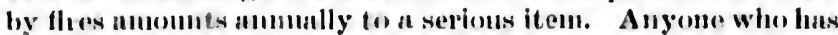
been in " district aver which a llie has renently passed will appreciate the utter ruin of the distriot for several yours for the tomist, the humter, and the angler ; and we belice that every true sportsman is glat to do anything in his power tos prevent destenction of the forests and will observe curcefully the following suggestions of the flie rungers:-

"The greatest ane should be exercisad hetworl $\Lambda$ pril lst "and Oetolser 31st, and if a fire is made in the forest, or " "nt a distance of less than a half a mile therefom, or "pon "any islund, for eooking or obtuining warnth, the muker" "shoulil-

Ist. Select " loculity in the neightortood in which there is the smallest quantity of vegetable mat. ter, dend wood, branches, biush wood, diy lenves, or resinous tres;

2ncl. Clent the place in which he is about to light the flre by removing all vegetable matter, dend trees, bunches, linshwood, and dry leaves from the soil within a ralius of ten fect from the flre;

3hd. Wxercise and observe every restsonable ane and presution to prevent such flye from sprenling, and carrefully extinguish the sitme before quitting the plinee.

"Great care should be exereised to see that burning

"matchus, ashes of pipes ancl lighted cigars, or burning

"gun walling, or any other burning substance, should

"be completely extinguished befor's the sportsman lenves

"the spot.

"Two mueh care cannot be exereised in these important "mattes.s."

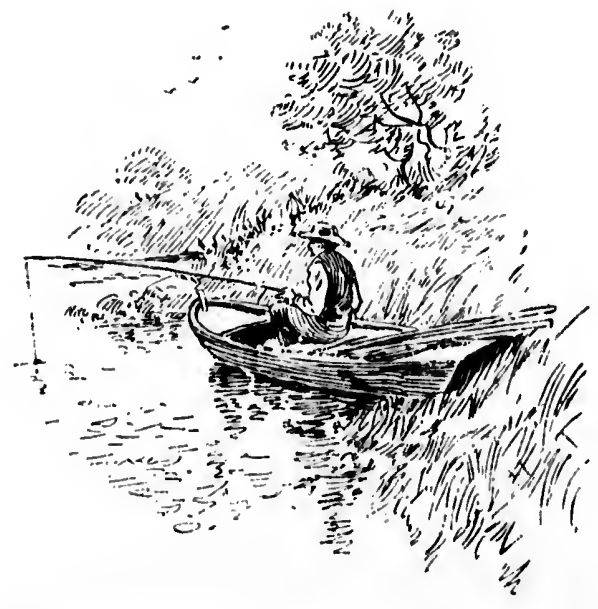




\title{
OPEN SEASONS
}

\section{FOR GAME AND FISH.}

\author{
A Synopais of Laws Governing Shooting and Fishing in the Provinces \\ and States traverned by the Canadian Pacific Ry. System \\ Changes are likely to be made during present sessions of the Legislatures
}

\section{REGULATIONS APPLICABLE GENERALLY IN PROVINCES AND STATES}

The Provincial and State laws generully prohibit possession or sale or transportation in the close senson for game or fish, except that after the open senson closes $n$ short time is allowed in some states and provinces, but in muny export is illegal at uny time.

Netting game fish or entching or killing them by drugs, explosives, etc., or by any other meuns thın hook and line is forbidden.

Insectivorous and song birds, and nests and eggs of all birds, except birds of prey, are protected at all times.

Netting or snaring gume birds, or killing by any other mode than shooting is illegal.

Night shooting is generally prohibited.

Streams or lakes lensed to individuals or clubs cannot be flshed ly the public, though in many cases persons properly introduced many olitnin fishing.

The following condensations of the Game Laws, etc., have been carefully revised, and made as correet as possible up to the date of the issue of this pamphlet. Owing to the fact that the Gane Laws are frequently changed, absolute accuracy is not guarantced.

\section{PROVINCE OF QUEBEC}

\section{(OIEN SEASON)}

Big Game. - Moose and Deer, September 1st to December 31st, excepting Ottawa and Pontiac Counties.

Moose and Deer in Ottawa and Pontiac Counties, October 1st to November 30th.

Caribou, September 1st to Januiry 31st.

Bear, August 20th to June 30th.

No more than two moose, three deer, and two caribou may be killed in one season by any one person.

Dogs may be used for hunting red aleer only between Oetober 20th and November 1st.

The young of deer, moose or earibou, if only one year old or less, must not be killed.

Cow moose sliall not be killed. 
OTher Game.-Mink, otter, marten, pekan, fox (except yellow or red), raccoon, November 1st to March 31st.

Fox (yellow or red), at all times.

Hare, November 1st to Janwary 31st.

Muskrat, April 1st to April 30th.

Beaver is protected until November 1st, 1902.

Game Birds.-Woodcock, snipe, plover, curlew, tatler, sandpiper, September 1st to Janıary 1st.

Birch partridge, swamp partridge, September 1st to December 14th.

White partridge (ptarnigan), November 1st to January 11st.

Widgeon, teal or wild duck of any kiıd, except sheldrake, loons and gulls, September 1st to March 31st.

Buffle-head ducks, eommonly known as pied-ducks or divers, September 1st to April 14th.

\section{WASTE OF GAME}

No person who has killed or takell any bird or animal suitable for food shall allow the flesh thereof to le destroyed or spoilt, and no person who has killed or taken a fur-bearing animal shall allow the skin thereof to be destroyed or spoilt.

EABT AND NORTI OF BAQHENAY RIVER

Regulations for that part of the counties of Chicoutimi and Saguenay to the east and north of the River Saguenay are the same as the foregoing, except that the open season for caribou is from September 1st to February 28 th, and

Caribou, not more than four may be killed in one season.

Otter, open season October 15th to April 14th.

Hares, open season Octch in 15th to February 28 th.

Musk rats, open season November 1st to Mareh 31st.

Birch or swamp partridge, open season September 15th to Janunry 3lst.

White partridge (ptarmigan), open season November 15th to February 2sth.

\section{NON-RESIDEN'TS' LICENSE-ENTIRE PROVINCE}

Non-residents are required to obtain licenses, which may be procured on application to General Passenger Agent, C. P. Ry., Mont"eal, through any agent of the C.P.Ry. Fee, $\$ 25.00$

for seasson.

Fish-(Entire Province).-Bass, from June 16th to April 14th.

Maskinonge, from July 2nd to May 24th.

Pickerel (dore), from May 16th to April 14th.

Speckled trout, from May lst to September 30th.

Lake trout, grey trout, or lunge, from December and to Ostober 14th.

Salmon, from February 2nd to August 14th, but may be caught by fly flshing with rod and lines to August 318t. 
Whitefish, from December 2nd to November 9th.

Ouinaniche, from December 2nd to September 1.1th.

Non-residents are required to procure licenses to fish. which may be obtained on application to the General Passenger Agent, C. P. Ry., Montreal, through any agent of the (impiny. The fees are $\$ 10.03$ for one month; $\$ 15.00$ for two months and $\$ 20,0$ ) foi three months.

\title{
PROVINCE OF ONTARIO
}

\author{
(OPEN SEASON)
}

Bic Game.-Deer, November 1st to November lith.

Mouse, caribou, elk, reindeer, November 1st to November 15 th.

Bear, ill yeatr.

Otuer Game.-Fox (yellow or red), at all times.

Hare, September 15th to December 15th.

Rabbits, any species, at all times.

Muskrat, Jamuary 1st to April 1st.

Blinck ar grey squirrel, September 15th to December 15th.

Beaver and otter are protect ed until Novembri 1st, 1900.

No more than two deer may be killed in one season by any oms perso ..

Dags may be used hunting deer, but must not be allowed to rum at large.

The young of deer, if mly one yenr old or less, shall not be killed.

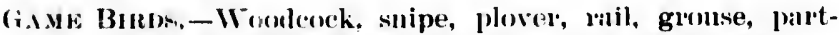
ridge, pheis:ant, Septeuber 15th to Derember 15th.

White partridge (ptarmigan), September listh to December listh.

Wild duck of all kinds, September lst to December lith.

Qunil, October listh to December listh.

Swans or geese, September lith to May lst.

Wild turkers, proterted until October listh, 1900.

Prilirie fowl of English or Mongolian phorisant. protected until september 1:ith. 19\%o).

\section{NON-RLSIDENTS' IICENSE}

Non-residents are required to obtun licenses, which may be procured on application to Genomal Passeuger Agent, O. P. Ry., Mont real, through any agent of the C.P. Ry. Fee, \$2;.00 forl seisull.

Fisit, - Bass, frou June 16th to A pril 14th.

Maskinonge, from Jume 16th to April 1.1th.

lickerel (diore), from May 16th to . I pril 14th.

Speckled trout, fom May 2nd to September 11th.

Silmon trout, foun December lst an Oetoloer 3lst.

Whitefish, foum Iecember lat to Oetober 3lst.

\section{FISHING LICISNSLES.}

Non-residents are required to olotain liconses to flsh, which may bo procured on npplication to the General Passenger Agent, (. P. Ry.. Montreal, through nny ngent of the Company. 


\section{ONTARIO GENERAI FISHISRY REGUIATIONS.}

1. Fishing hy menus of any kind of net, seine, snare, ruck, trap, weir, night-line, set-line, spenr, grnpmel, negog or nishg:ı or by any other means or apparatus whatever, without a fishing lense, license or permit from the Commissioner of Fisheries having heen first obtained, is prohibited; but nothing in this section shall prevent angling without a license for any fish except sturgeon. But no sturgeon shall be caught, taken or killed by any means whatever withent a license first had and obtained.

2. No person shall take, catch or kill in any of the waters of this Province in one day by angling. or shall earry away, a greater nunber than twelve black, or Oswego or large-monthed bass, twenty green hass, twenty pickerel, or foul maskinenge.

3. No person shall take, catch or kill in any of the water's of this Province by angling or by any other means whatever, for the purpose of barter or sale, from the first day of Decenber to the fifteenth day of $A$ pril, both dnys inclusive, any black bass or Oswego, or lange-monthed bass, withont a license first had and ohtained.

4. No person shall take, catch or kill in any of the waters of this Province, in one day by angling, or shall carry away, a greater mumber of speckled or brook trout thun in the aggrogate shall weigh more than fifteen pounds, and no greater number thin fifty speckled or brook tront, thomgh said mumber weighs less than fifteen pounds.

5. No bass less than ton inches in length, no sprekled trout loss than six inches in length, no pickerel less than twelve inches in length, and no maskinonge less than fifteen inches in lengtl, shall be retained or kept ont of the water, sold, offered or exposed for sale, or had in possession; but every person who takes or catches any of the fish mentioned of less than the ninimum measurement named (which measurement shall lo from point of nose to centre of tuil) shall immediately return such undersized fish to the water from which they were taken, alive and, in so far as possible, minjured.

(b. No mon-resickent. tourist on summer visitor shall take, (atteh or kill in my one day, by angling in the inland lakes of this Provinee, or shatl calry away, a greater number than ten lake trout, any one of which shall exceed three pounds in wright; nor, in the alternative, " greater number of lnk" trout of a less weight than three pounds ench, than in the nggregate shall weigh more than twenty pounds.

7. Subject to the andition rontained in the preceding saction, no persim shall by any means whatever take, eatch or kill, or shall buy, sell or offer or expose for sale, or have in possession any salinom tront, lake trout or whitefish weighing less than two pounds in the round ior unclressed, or which when dressed weighs less than one poumd and three-(juarters, or any sturgeon of less than ten poumds in waight.

8. The worls " nom-resident, tourist or summere visitor," when and where used in these Regulutions, shall include any and all persons who muy during the spring, summer or antum wonthe be tempormily visiting, boarding, lolking or domiciled in any lowality at a distance of over flve miles fiom his or their usual place of resiblonce at other times of the year. 


\section{ONTARIO-NEPIGON LAKE ANI) RIVER FISHERY REGUIATIUNS.}

1. No person shali fish by angling in the said waters without first having obtained an angling license or permit from the Commissioner of Fishories through the lncal overseer at Nepigon.

2. One angler's license or permiti only may be issued to each applicunt. and shall not be for a longer period than two weeks from the date of issue.

3. The fee for such !icense or permit shall be $\$ 10$ where the applicant is not a permunent resident of Canadia : \$2 where he is a permanent resident of the Algoma, Rainy river or Thunder Bay districts, and $\$ 5$ to all other residents of Canada.

4. The holder of such license or per'mit shall not cutch or kill in one day, or' car'ry away, a greater number of speckled or brook trout than in the aggregnte shall weigh more than 15 pounds, or a greater number than ten speckled or brook trout in any one day, though said mumber weiglıs less than 15 pounds.

5. The satd license or permit shall not be trmusferable, and the holder thereof shall produce and exhibit the same whenever called upon so to do by a fishery oversees.

6. All fishing comps and fishing parties visiting the said waters shall be subject to the supervision and dirertion of the fishery overweer or overser.r's.

7. Such sulitary arrangements as the over'seer may direct shall bo marle, and such dircetions as he may give as to the disposal of refuse and the extinction of fires shall be complied with.

8. The ent ting of live timber by persons holding a license or permit to angle in snid waters, their scrvants or agents, is prohilited except where nbsolutely necessin:y for the purpose of camping and shelter, such as tent poles, tent pins, etc.

9. These regulntions shall apply to Indians who nuy act as guides, bontmen, canoemen, camp assistnut sor helper's of any kind of any fishing party or person or persons who may hold n fishing license or permit during the time they ar' angaged with such party, person or persons, but not otherwise to luelians: but no Indian shall fish with net or trip or night linc or other'wise than by angling in the said River Sepigon or any other of the creeks or streams tributary thereto.

\section{PROVINCE OF NEW BRUNSWICK}

\section{((IPJW RE.LSON)}

The game laws of this Province were altered at the recent session of the Regislature, but wili not come into operation until proclaimed by the Lient.-Governor-in-Conneil. The following is a summary of the laws previous to the revision :

Eig Game.-Moose, enribou, deel or red deer, from september 15th to December 3ist.

Cow and female calf moose are protected nt all times.

A close season for moose and caribou his been established west of St. John river for' two yenrs from Sept. (-ulluev 1st, 1808. and for moose, caribon and deer in the County of Albert for five years from September 1st, 1608. 
No person shall kill or take more than one moose, one caribou and two deer during any one year.

OTHER Gamk.-Mink, fisher or suble from September 2nd to April 3xth.

Beaver protected until March 20th, 1901.

Moose, caribou and deer are not to be hunted with dogs, or to be cuught by means of traps and snares, or at night by means of artificial light or lights. Hunting and shooting of animals and birds on Sundays, prohibited.

Gaue Birds. - Partridge, from September 21st to October 31st.

Woodcock and snipe, from Septenber 2nd to November 30 th.

Wild geese, brant and black dinck, from September 2nd to November 30th.

Wild duck, brant, wild geese and other wild fowl of a ganne kind shall not be hunted with artificial light, nor with swivelor punt guns, nor trapped or netted at any time.

Sea-gulls, pheasants, song-birds and insectivorous birds, entirely protected.

Sunday shooting is prohibited.

Fish.-Sea trout. April 1st to September 30th.

Land-locked salmon, May 2nd to September 14th.

speckled tront, lake and brook trout, May and to September 14th.

Bass may be caught with fly or bait all the year around.

Salmon, February 1st to August 15th, by fly fishing with rod and line.

The use of explosives or poisonous substances for killing fish is illegal.

\title{
LICENSES
}

Non-residents must not kill uny moose or caribou without having obtained a license from the Crown Lands Office, Fre lericton, N.B., or from the Chief Game Commissioner, or any county or special game warden, by payment of a fee of $\$ 20$; license to be in force for one year. License for residents, $\$ 2$.

\section{PROVINCE OF NOVA SCOTIA}

\author{
(OPEN SEASON)
}

Big Game.-Moose, October 2ud to January 1st.

Caribou, October 2nd to Jinuary 1st.

Bear, all year.

Deer and elk, protected until Octoher, 1904.

Oтнен Gase.-Mink, November 2nd to Febunry 28th.

Fox (yellow or red), at all times.

Hare or rabbit, Octoler and to Jinunry 31st.

Muskrat, November 2nd to March 31st.

Beaver is protected until November Ist, 1900.

Newfoundland hare and jack-rabbit, protected.

No more than two moose and two caribou may be killed in one season by any one person.

Dogs unust uot be used to hunt caribou or moose.

The young of deer, moose or caribou, if only one year old or less, shall not be killed.

Cow mioose shall not be killed.

Gamk Butds.-Woodcock, snipe, teal, blue-winged duck, wond duck, September 2nd to Februnry 28th.

Partridge, proteeted until Octoher, 1901. 
Gape Bretom, the open senson for all birds (expopting partridge) is from Angust 20th io Folnulary $28 t$ h.

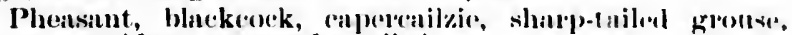
sprice partridge, protecterl at all timess.

\section{NON-RIEIDENTS' IACENSE}

Nom-residents are recpuired to obtain lierouses frum the Provineial Srecetary to shont-Big game, \$s30); bilels and i"iblits, \$10.

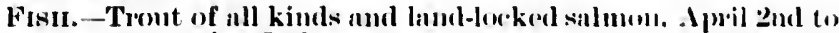
September 30th.

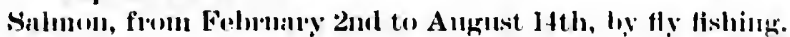

\section{FISHING LICENSHS}

Non-residents are rempined to obtain licenses (1) lish, whirh

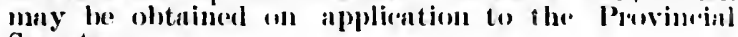
secretiny.

\section{PROVINCE OF MANITOBA}

\section{(oPlis ge.ISG)}

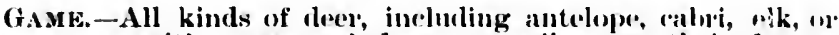
wopiti, moose, reinderer, of entilun, of their fawils.

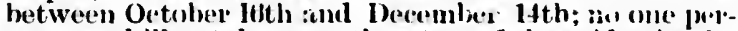
son ruay kill or take inore thin two of the sitid animals. This does not ap!hy to dreer which are private property and taken onl his own lands and prentises in or with the comsent of the owner.

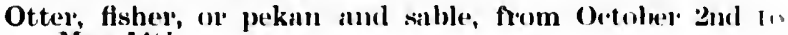
Miny $14 t h$.

Muskmat, from December 2nd to April 30th.

Marten, fom November 2nd to April lath.

Beaver, perpetually protected

GaME BIRDS. - All varieties of gromso, including prairio ehicken, pheasant and pautridgess, between Octoberp end and November 14th, mul it is allegial for onn porson to kill more than 100 in one yeir or more thim 21 in one day.

Wondeock, plovere, suipe and sandpipers, bet ween Augunt mel and Deeeninine B3ist.

All kincls of wilal duck, se: dluek, wilgenul, teill, betwern Septensher end and A pril : 3 ith.

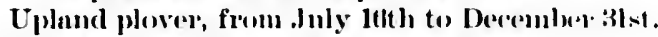

sumblay shooting is antirely prohibited.

\section{NON-RESIDEN'TS' III'LNSES}

Nontersidents of the Provines must sarme al homting

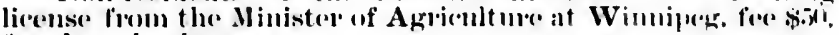
for the calendar your.

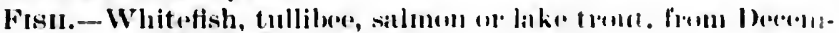

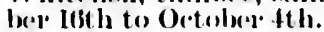

Pickerol (done), from llity lith to April Ith.

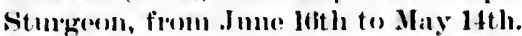

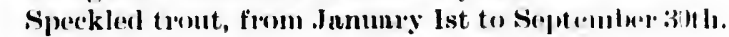

\section{THE NORTHWEST TERRITORIES}

\section{(o) SEN SASUN)}

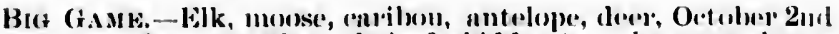
to. Janumey :31st. (It is forbidelen to take mure than th head in mily one sensom.)

Mountain sheep or goat, Ootober 2nd to .Jannary 31st. IIt

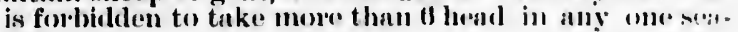
s(111.)

Mink, fisher or marten, Novernlese 2 nd ta April dith. 
Ottel or be:tver, Outober End to May 14th, except in East Assiniboin where beaver are protected until November, 1901.

Muskrat. Novomber End to May 14th.

Butfinlo are protected nt all times.

Smal., fiamk.-Gionse, partridge, phensant or prairio chicken, Septomber 16th to Decemb(r) 14 th--and no more than 20 in one day.

Wild duck of all varieties from August 24th to May 14th.

Plover, mipe or sandpipar, Angust End to Derember 31 st.

No person slunll tuke or kill more than three aleer of any inc speries in any year.

Fisu.-Speckled trout from Junumy and to september :30t h.

Pickercel (doré), from May loth to $A_{\text {pril }} 1 \mathrm{fth}$.

\section{NON-RESIDEN'T PERNITS.}

P(ermits are grantrd by game gumilians for' periods not exceoding five dnys to my mon-rosident, who is the bonn fide guest of a rosident, to hunt in company with his hust. Aftldivits must be unde by the applicant and such resiolent. Fee. $\$ 1.00$. Shonting Licenses, issurd hy Minister of Agriculture, $\$ 15.1)$

\section{PROVINCE OF BRITISH COLUMBIIA}

(b) EN REANoN)

Bra (i.1.y 6..-Monse (bull), Septembor lst to December 31st. Finules, and culves under one yorar, protected.

Derr. September lst to December 14th (fawn protected at ill times).

('uribu, Septomber lst to Docomber 31st. l'omales and (alves, protocted at all times.

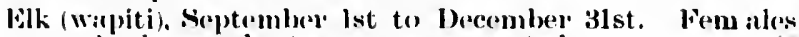
iud calves under two years, protected.

Mount ain goat and sheep, Sintember lst to becember 14th. Momtain sheep, ewes and lambs, protected.

Not nore than five caribon can be killed by one person in "11y seisoll, 1101 Inore thmu ten deer, two (bull) elk, two (hull) moose, five momntain gont or three momntuin shoce (rims). Deer must unt he hunted with dogs, or killod for hides alone.

S.IAt.l. (iAyk.-Beaver, November 2nd to March 31st.

Harr. Siptember lit to December 31st.

lalul ottur and marten. November 2ud to March 31st.

GAyE Burus. - Bittrrn, Suptembor lst to February 28 th.

Durk of all kinds, September lst to lieburary 28th.

H(r)ul, plover, and grouse of ull kinds, including prinire chickens, Septenker 1st to I)ecember 31st.

Partuidge (English), pheasants, quail of all kinds mo pintectod.

Not mole than 250 ducks can be shot in one season.

Inseretivorous birds always protected.

The buying and selling of hends of mountmin sheep is prolibited.

Fish,-Fipeckled trunt, fiom March 16th to October 14th.

Silumon trout, from December lst to Siptember 30th.

Sinluon angling, from March 2nd to Octolor ix)th.

Sturgeou, froun July loth to Muy 3lst.

Whitetish. from December lst to September 30th.

\section{NON-RESIDENT'S' LIOENSES}

Nim-residents, other thmn militury men of the British Army and (anudiu Militin in actunl service in the province, are repuirod to secure shomting license-fee 850 -which mny be procured from nuy Provincinl Government Agent. 


\section{NEWFOUNDLAND}

(OPEN AEASON)

GAME.-Curibou, from July 16th to January 31st, exeepting from October 7 th to October 2uth (inclusive).

Otter, October 2nd to March 31st.

Rabbits and hares, September 16th to Folnuary 28 th.

Beaver, from October 1st to March 31st.

Moose and elk, protected until Janumy, 1006.

Not more than three stag and one due carihou to be killed in any one year by any one person.

Dogs must not he used to lumt carilon.

Game Binds.-Partridge, ptarmigun and other grouse, September 16th to January 11th.

Curlew, plover, snipe or other wild or migratory birds, excepting wild geese, August 21st to January ilth.

Fish. -Salmon, grilse, or parr or trout, in uny lake, river, pond, brook or stream, Jannary 16 th to September 9 th.

\section{NON-RESIDENTS' LICENSES}

There ure three kiuds of licenses-one entitling the holder thereof to kill and take two stag and one doe caribon, $\$ 40$, valid for four weeks ; nnother to kill three stang and one doe carihou, $\$ 50$, valid for six weeks; and a third to kill five stug and two doe caribou, $\$ 80$, vilid for two months.

Export of carcasses per'mitted under certain conditions.

\section{STATE OF VERMONT}

\section{(11EN SEASUN)}

Game-Deer, from October 22nd to October 30th.

Rabbits and hares from September 2 nd to April 30th.

Beaver, fisher and otter, from November and to March 31 st.

Ruffed grouse (partridge), woodcock, quail, wild duck, English snipe, wild goose and plover, from September End to December 31st.

Sharp-tailed grouse, pinnated grouse, capercailzie, black game, ptarmigan or pheasant, protected till Jannary 1st, 10(6).

Upland plover from Angust 16th to November 30th.

English partidge from Octoher End to November 19th.

Deer or game birds taken from the State must be accompanied by the owner, and plainly labelled with owner's nume.

Dogs must not be used to hunt deer.

Fisf.-Black hass, from Jume 16th to December 31st. When taken less than ten inches in length, must be returned to witer.

White perch, muskallonge, June 15th to A pril 14th, except in Lake Chnmplain.

Wall-eyed pike, pike perch, from Miry 2nd to December 31st, except in Lake Champlain, where season is through. out the year with hook and line.

Trout, land-locked salunon, and salmon trout or lunge, from May 2nd to August 31st.

Brook, rainbow, brown or Iock Leven trout when less than 6 inches, and lind-locked salmon, salmon tront or steelhend trout less thun 12 inches, must be returned to the water. 


\section{STATE OF MAINE}

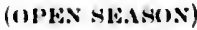

Bic (;.м. - Moose, from Oetober lotli to Noveuber :3uth. Deer, frow October end to December I/tl.

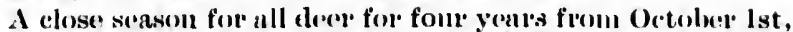
18409, has bern establisherl in counties of York. ('mulnerand,

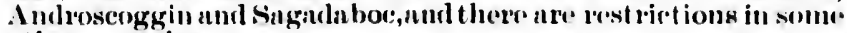
other conntie's.

Caribon, protected intil Oetober1, 19\%5.

('i) and enlf monse, protecturl.

Dogs must not be used to hunt moose, andilom al aleer.

No peison shall kill more than ane lull mocse of more than two dors in one seasin.

Oтнев Gama-Mink, sable ol Hsher, from October 10th to April :30th.

Muskint, from October 16tlı to April :30th.

Beaver, protected to Murch, 1003.

GAME BirDs. - Wood dıck, dusky diıek (commonly culled blick duck), teal, gruy duck from September and to April 30th. Rulferl grouse (comum only called partriclge), from September loth to November $30 \mathrm{th}$, and can not be exported it any time.

Woodcock, from September 16th to Niviember 30tb.

Quail, from October 2 nd to Novenber $30 t l$.

Plover, snipe und pipers from August 2nd to April 30th.

No person shall in auy one day kill more thun 15 of ench varioty of aluve bircls.

(inpercalzie, or cock of the woods so ealled, black game: so ealled, or any species of the pheisint, except ruffed giouse or partridgc, are protectod for 10 years.

Sunday is a close time for all game.

Fisf.-Land-locked salmon, tront, togue and white perch, from May and to September 30th, excepting in St. Groix and tributuries, and waters in Kennebec county, l2th Mav to September 14th; also on certain streams around Rangeley Lakes, from May 2nil to June 30th. White perch frou July und to Murch 3lst.

Residents may fish during February, March and April, excepting where prohibited by special law.

Salmon, from April 2nd to July 14th, lut may be taken with rod and single line from July 15 th to Sept. 15th.

land-locked salmon trout, togue or white perel not to be t]ansported except in possession of the owner, and not more thin 25 lbs. of ench by one persous.

\section{STATE OF MICHIGAN}

\section{(OPLN SELAO)}

Gask-Dere, November 8th to November 30th. Deer proterted in comtios of Algona, Lilperer, Huron. Sanilate, Tuscoli, Matomb, Illegon, Ottawa alirl Sit. ('lair until Jallaty, 1903.

Dogs must not be used to hunt deer. No person shall kill more thitn flve drer in any onc siason.

Purtridge, (puil, spruce-hou, snipe, plover and woodeock, Oetober 2(1)th to Nov, 30th.

Partirige in Upper Peninsula, from October lst to November 3otl.

Pruiric chicken protected until 1000.

Ducks, geese, brant and other wild water fowl, September lst to Jumumy 31 st, and then onlv from one-half hour before sunrise until oue and $n$ half hours after sunset. In the upper peninsula. any wild fowl may be killed frou September Ist to Jamuary linth, inclusive. 
Plur bill, canvis back, wirlgeom, pin tail, whistler, spoon bill, lutter ball, saw bill dlucks and wild geese, Neptember lst to . Noy lst.

Squirrels, from October 1st to Decomber 31st.

Wild pigeon, Mongolian and Fnglish pheasants protected until 1005. Nests and egus und insectivorous hirls, perpetually protected.

(1) Ist, rland, I sollit!

H:

more

10tlı

cralle'd

Api·il

from

portel

th.

f ench

game:

inffed

verch,

n St.

unty,

enms

30th.

Lpril,

aken

toth.

to be

nore

pro-

ilue.

intil

kill

ck,

to

beI

oni.

et

led

\section{STATE OF WISCONSIN}

\section{(OPEN SEASOIN)}

GAME. - Deer, from November and to November 19th. Duer in comntius of siliehovgan and Fond du late protected until April 10th, imge. Not more than two may be killed hy one mun in one season.

Dogs must not be used to hunt deer.

Rabbits, otter, fisher und marten, Octoher and to April 3otl.

Woodeck, partrilge, pheusant, pririe chicken, or prairie hen, grouse of all kinds, plover, snipo, September 2 nd to November 30 th.

Wild duck, or br unt, or any nquatic fowl (including snipe), excepting will geese, September 2 nd to Decrmber 3ist.

Will gecse, from S(p)tember 2 nd to April 30th.

Swan, perpetually protected. Insectivorous birds always protected.

Mongolian, Chinese or English pheasints, and qunil of all virieti s, protected until September, 1901.

Fisн.-Trout, all virieties, April 16th to August 31st.

Black, yellow and Oswego bass, May 20 th to Fehruary 28th, except in certain counties.

\section{LICENSES}

Residents, \$1.00; Non-residents, for deer, and all other game (nut protected), \$25.00; all game (not protected), except †eer, \$10.00.

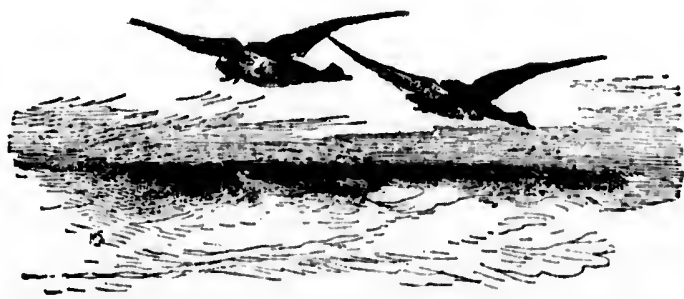




\section{List of Agencies}

Amoy ........ Chlna..Jardine, Mathenon \& Co.

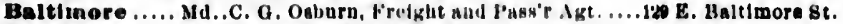
Hatavia...... Java...MacLalne, Watron \& $C u$.

Bombay ..... Indta. Ewart. Lacham * Co. Thomaa Cook \& Son, 13 Rumpart Koad Boston .......Mase. $\{$ If. J. Colvin, Dlatrict Pasenger Agent.....197 Washlugton St.

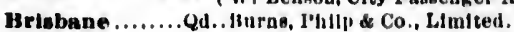

Hrookville...... Ont., (teo. F., Metilade, Theket Agent.. ........ \{ Cor. KIng St. and

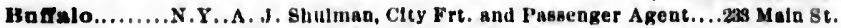

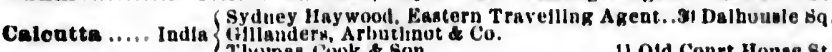

T Tiumas Cuok \& Son.....................11 Old Court House st.

Centen....... China..Jardine, Matheson \& Co.

Chembipo... Korea...IIolue, Mlıger \& Co.

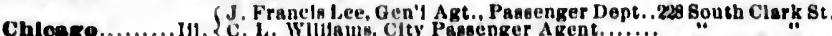

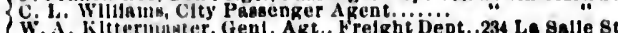

CinolneatI.... Ohlo..Geo. A. Citfurd, Trav, Pasa'r Agent... \{ lloom I), Chamber uf

Colombo... Ceyjon. Buls IIros. Thomar Cook \& Son (E. B, Creasey).

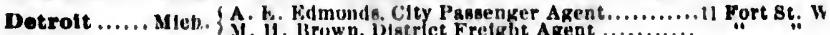

Daluth .........Mina .. T. II. Larke, Dlutrlet Agent.........426 spalding IIouve Block Glesrow .. Scotlend. Archer Baker, European Trafic Manager...,67 8t. Vinoent St. Hallfax ......... N.8..J. D. Chipman, Clty Jasaedger and Frulght Agent, jor Hollto st. Hamilton ....... Ont. . W. J. Grant, Commercial Agent..... Cor. KIng and Jamou Bta. Binkow ......Chlne..Jardine, Matheson \& Co.

Hons Kons.......... D. E. Brow a, General Agent, Chins and Japan, etc.

Eonolnin ........II.I. Theo. II. Davlen Co., Liulted.

KIngaten..Jamalcs..Gerald A. Morale.............Cor. Port Irogel and Orenge Sta. Kobe............Japan...t. Mlllward.

Wiverpool ..... Eng.. A rcher Baker, European Trame Manager.......... 7 James 8t. London ....... Eag. $\{$ A rcher Baker, European Trafllc $\{67 \& 68 \mathrm{KIng}$ WIIllam St. E.C. Lond. a ....... Ont..T. 12. Parker, Clty Pngsenger Agent............161 Dundes st. Melta ..................Turnbull, Jr., \& Somerville, Correnpondents.

Melbourne .... Aus..A.U.B.N. Co., Limited. Thonas Cook \& Sun.

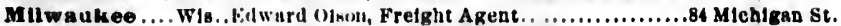
Minneapolle . Mlan.. W. B. Chandler, Agent, soo Llae...........110 South Thlrd St. Montreal ......Que $\{$ W. F. GRg. Ctty Paasenger Ageut............t29 St. Jeme St. M ontreal ......Que $\{$ J. Corbett, Furelga Frulght Agent..... Börd of Trade Bullding Nacrankt .... Japan. .llolme, Iltuger \& Co.

N. Wha:com. Wakh., W. H. Gordon, Passenger Agent ................1293 Dock St. New Yout .... N. Y $\{$ k. V. SkInner, General Eastera Agent............sss Brondwsy

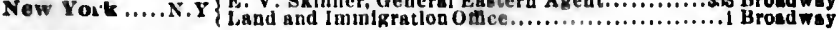
Niagara Falls. N. Y..D. Janac, Proepect llouse.

Ottawa .......... Ont..(ieo. ) )uacan, City Paggenger Agent .............42 Bparko St. (Hernu, Jeron \& Co., Ticket Aqenta..6i Boulevard Havasmann Internatlonal Sleeping Car Co................, 3 Place de jopera Thos. Cook Son ........................... place de jopera

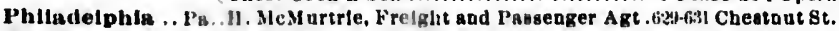

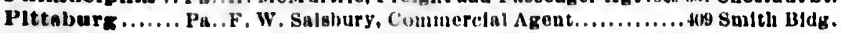
Portland.........Me..G.H. Thompson. Tleket Agent, Malue Ceatral IRd..Unlon Depot portland ....... Ore. If. II. Albott, Pasgenger Agent................146 Thlrd $8 t$. l't.Towngend. Wash. Wullam $\Lambda$. Pfelfer.............................. Taylor $8 t$. Quebee.........Que..li. I1, Criran, Clty l'nasenger Agent....... Opposite Pont Omce

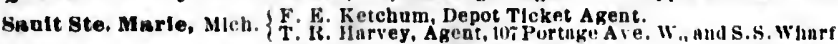

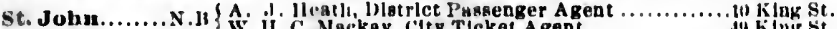
Mlackay, Clty Tickel Agent............ty king st. St. Louls ......... Mlu. W. Y. Porteoua, Frelght Agent.............315 Cheataut st. St. Pad .. .....Minu .W, \&. Thord, A.G.J'..., Soo Line.

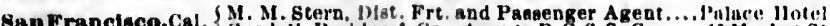
Goodall, Perkins do Co. A pente P.C.8.8. Co..... 10 Market St. Seattle ....... Wash.. W. R. Thomain........... Mutual Llfe Bullding, 600 Flrat Ave. Shan rhal .... Chlar, .Jardine, Matheaon \& $\mathrm{Co}$.

Sherbrooke ...Que..W. II. Buttum, CIty Pagnenger Agent.......6 Commerclel St. Bydnes ..........A us...IJurns, Phllp \& Co., LImited......................10 Bridge Bt. Tacoms ...... Wash..F. 13. Johngon, Fretght and Pangenger Agent.. 1028 Pactnc Av. Toronto...... Ont. A. I1. Notronn. Asst. Gen'l ['askenger A Rent..... Klng St. E.

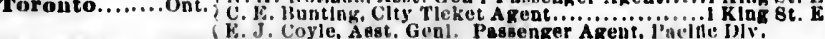

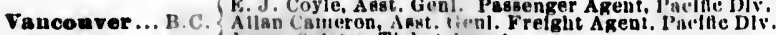

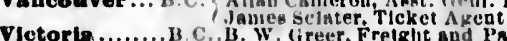

Vjetorta........ B . C..B. W. (ireer. Frelght and Panaenger Agent...Guvernment 8 . Washington... C..W. W. Merkle, Frelglit and I'Has'r Akt. T220 Penugyivenle Ave. Winnlper ......Man.. W.M.Mcl.end, City Tkt. A wt..Cor.Main Bt, and Mclermott A ve. Yoknhama...Japan.. Wu. T. Fype. Geaeral Truibe Agent for Japun .......14 Buad 
more $\mathrm{se}$.

art llond igton St.

St. and

19e A vo.

Main $8 t$.

unle ba.

oune st.

Slerk $\mathrm{Bt}$.

Balle $\mathrm{Bt}$.

mber of

uflalog.

st. W.

ve Block

cent $8 t$.

ollis $8 \mathrm{t}$.

Des 8 ta.

age Bts.

mes $\mathrm{St}$.

3t. R.C

. S.W.

Ides $\mathrm{St}$.

gan St.

bird $\mathrm{St}$.

men St.

ullding

ock Se.

oed w8y

mann

Martli

Opers

Opera

nut $\mathrm{St}$.

bldu.

Depot

Ird $\mathrm{St}$.

Ior

Offee

Wharf

lng St.

ne st.

aut sit.

llotel.

ces st.

Ave.

tat St.

ge st.

Ic $\mathrm{Av}$

St. $\mathbf{E}$

St. E.

int $\mathrm{st}$.

Ave.

Bund 


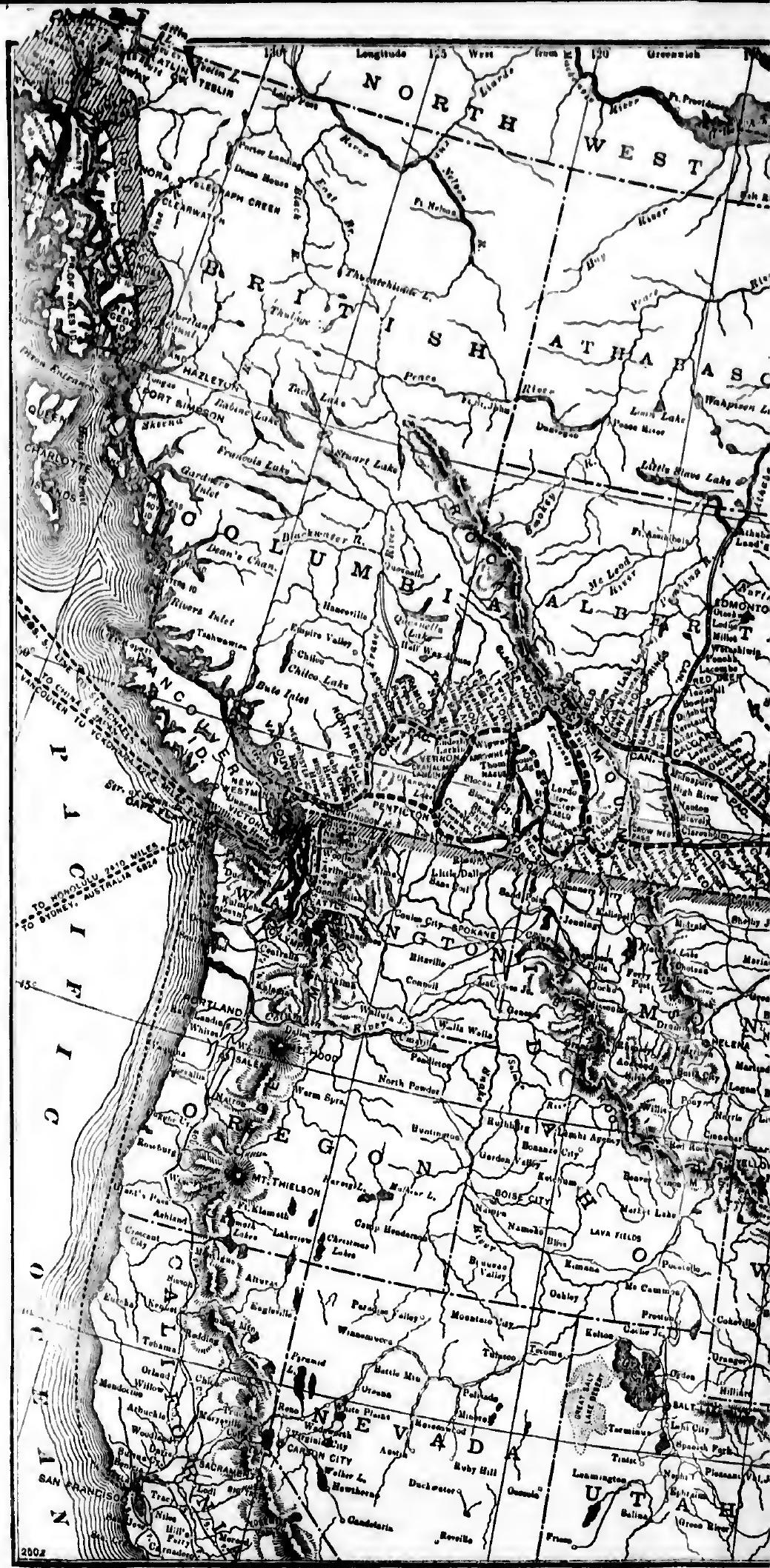




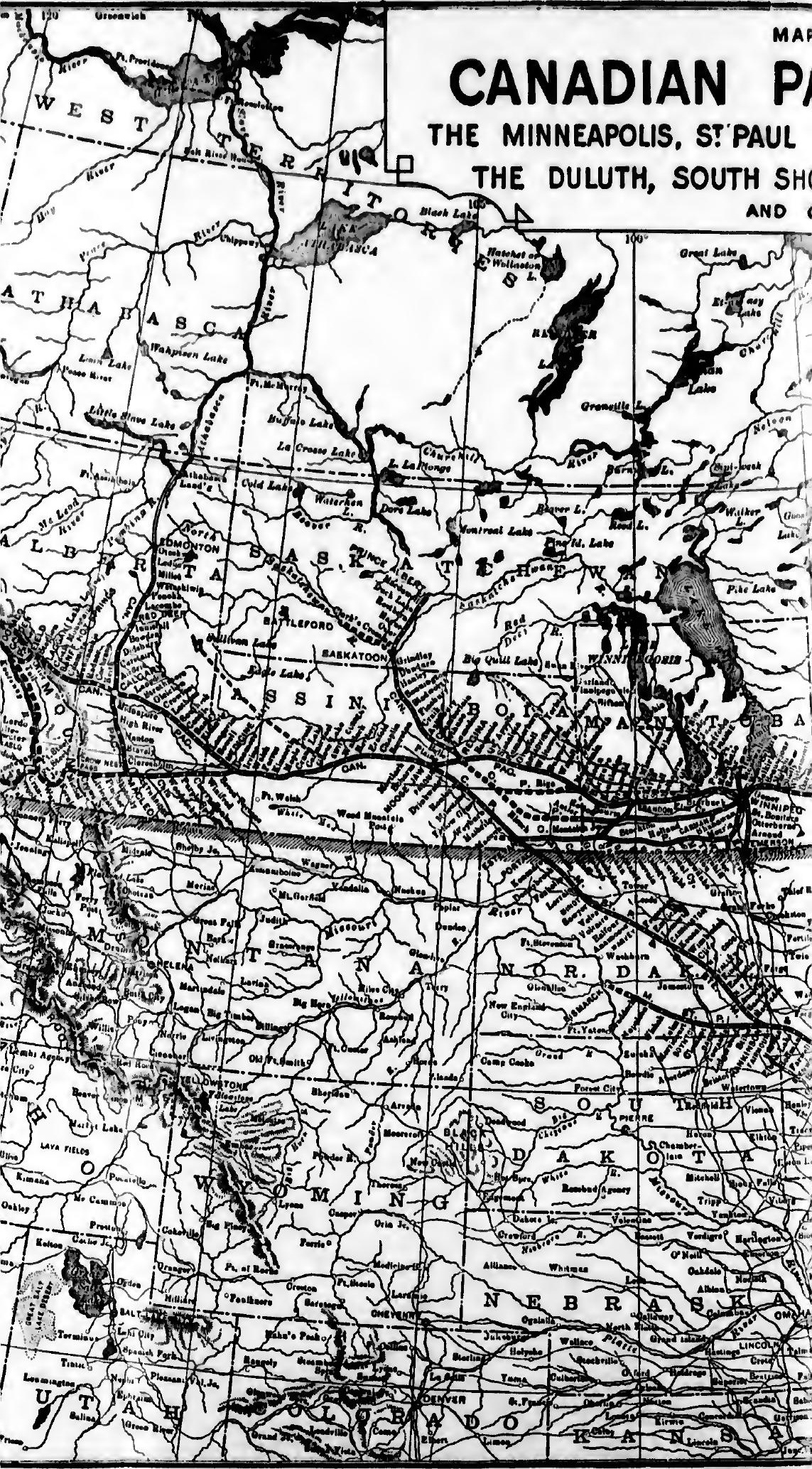




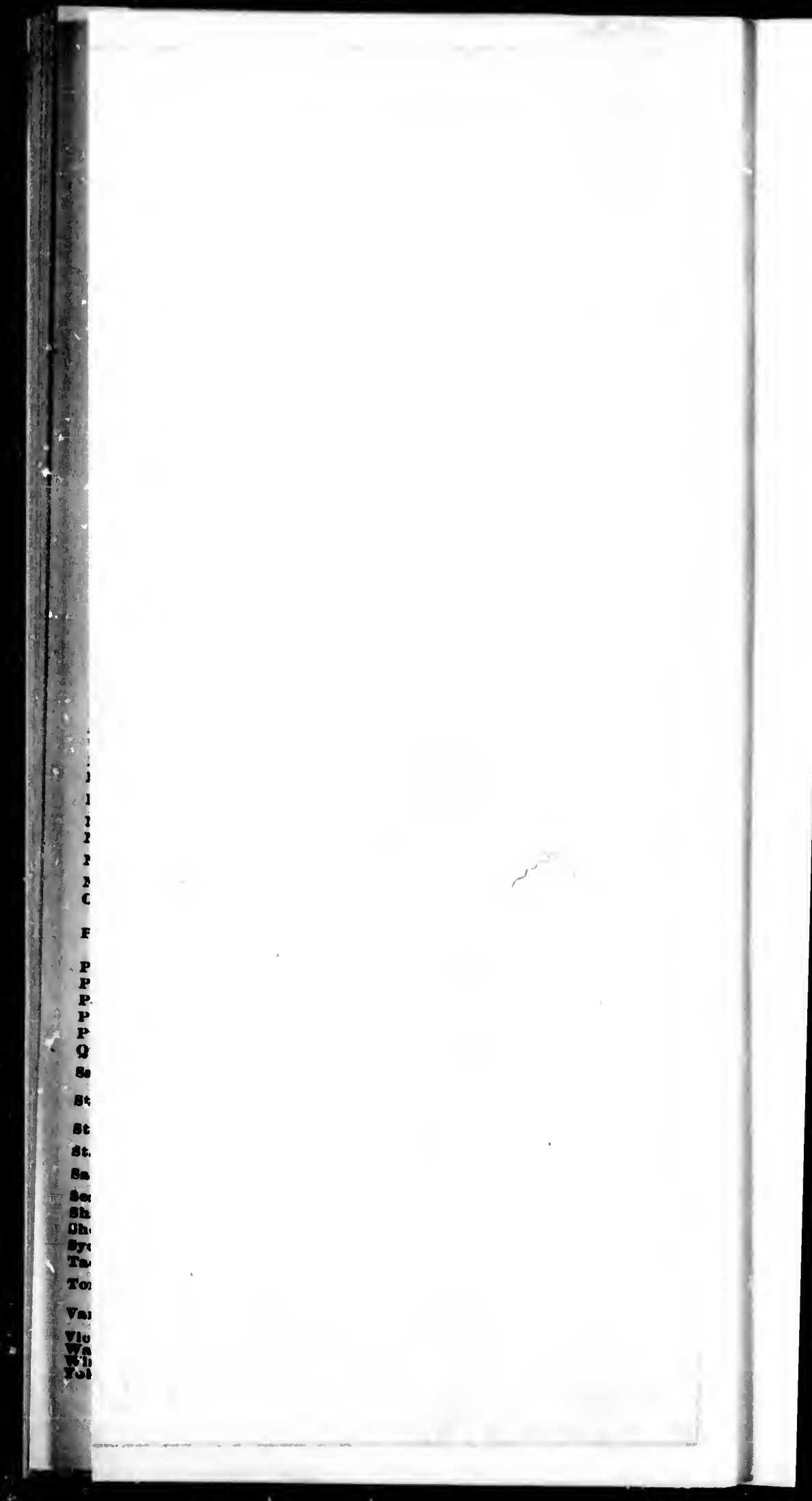




\section{Publications \\ Tssived by the \\ Canadian Pacific Railway Co.}

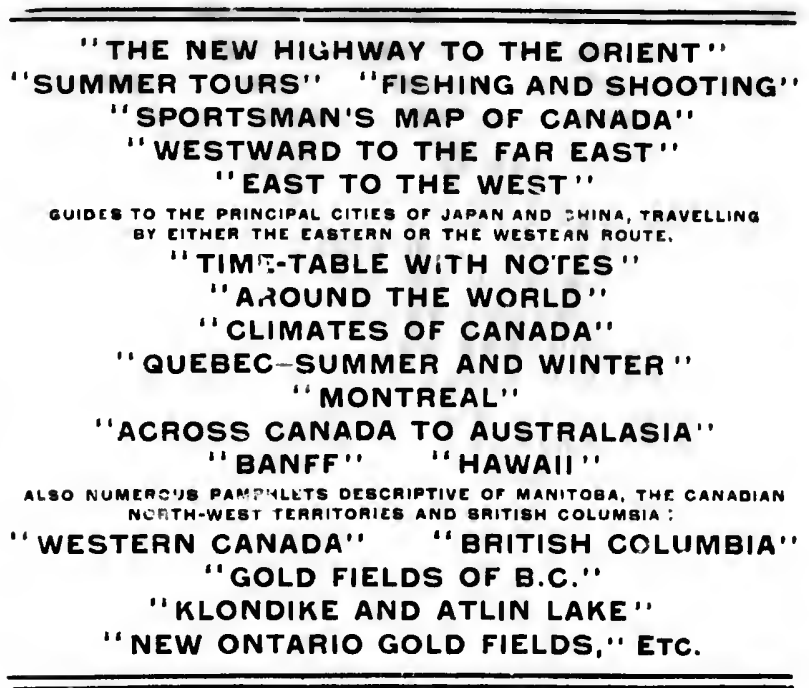

Most of these publications are handsomely illustruted, aml contain murh useful information in interesl ing shates. "lime-'ables with Nivtes will be fonnd in raluable companion for all trankentineutal trisellers.

Copies maly bo ohtulned Flakk from Agents of the Compang, or will be milled to any altirems on applieution to umlersigned.

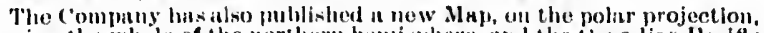

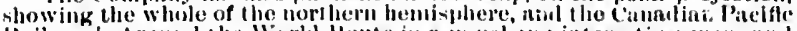

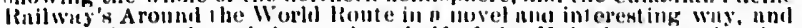
nother of Calladn and the hor thern linif of the Cuild states, sliowing

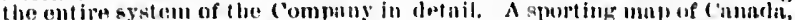

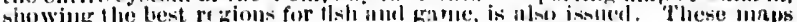
will be givill aw wy for public and montuent displity.

The C'ompany now has on sale in its hotels, prineipal tieket, offices, aul on the trails, sevoral series of hathesomely thished views of reenes along their lines of ritilwy, Size-12 $\times 10$ incher, in portfolios sultable for the table (12 views in each serient, price, \$1.00.

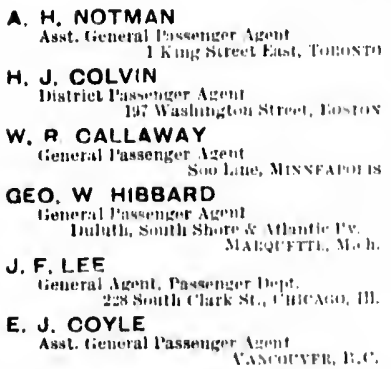

A. J. HEATH 1).shlite I'assengur Aganit

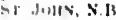

E. V. BKINNER

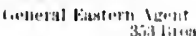

A. E. EDMONOS

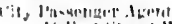

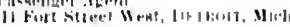

\section{M. STERN}

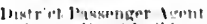

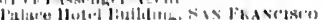

D. E, RROWN

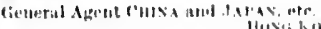

ARCHER BAKER, Fiurnjwat Trim. Mlanager

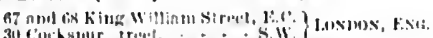

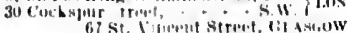

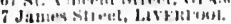

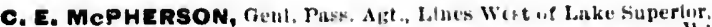

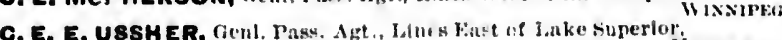

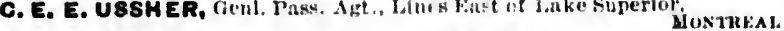
ROBT, KERR, Passelger Traffic Manager, MoNTnEAL. 


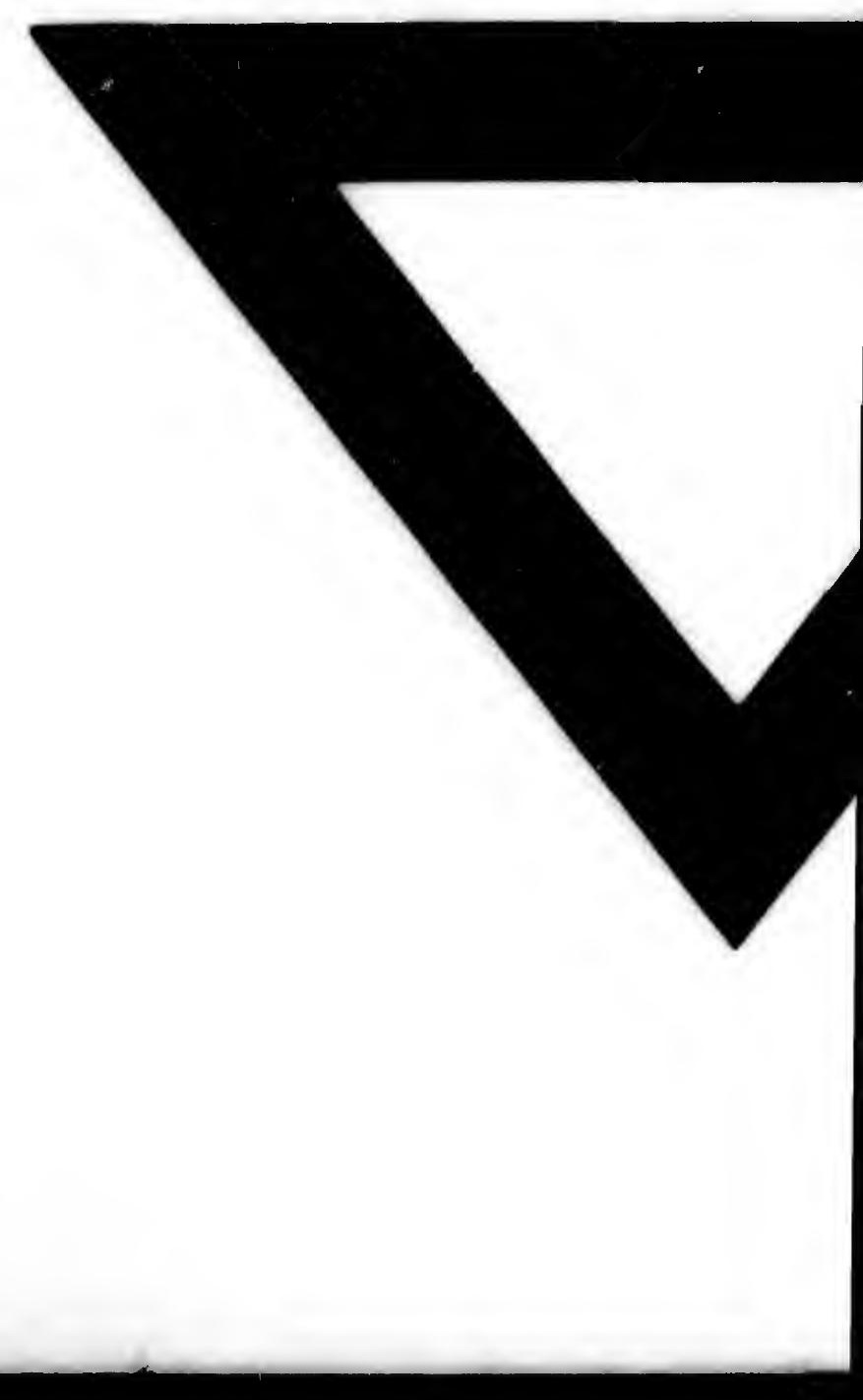




$$
\nabla
$$

